DEPARTMENT OF THE INTERIOR

UNITED STATES GEOLOGICAL SURVEY

GEORGE OTIS SMITH, DIRECTOR

BULTFTIN 443

RECONNAISSANCE

OF THE

GEOLOGY AND MINERAL RESOURCES

OF

PRINCE WILLIAM SOUND

ALASKA

BY

U. S. GRANT AND D. F. HIGGINS 



DEPARTMENT OF THE INTERIOR

UNITED STATES GEOLOGICAL SURVEY

GEORGE OTIS SMITH, DIRECTOR

BULIETIN 443

RECONNAISSANCE

OF THE

\section{GEOLOGY AND MINERAL RESOURCES}

OF

\section{PRINCE WILLIAM SOUND \\ ALASKA}

BY

U. S. GRANT AND D. F. HIGGINS

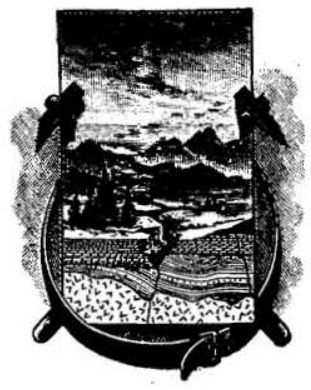

WASHINGTON

GOVERNMENT PRINTING OFFICE

1910

LIBKARY

TEXAS TECHNOLOGICAL COLLEGE

LUBBOCK, TEXAS 



\section{CONTENTS.}

Preface by A. H. Brooks....................................... 7

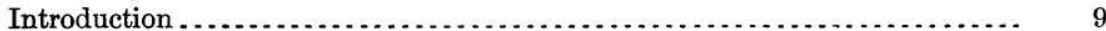

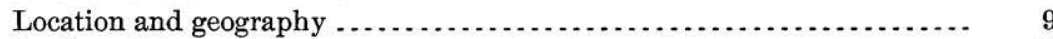

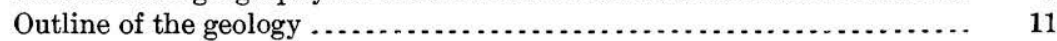

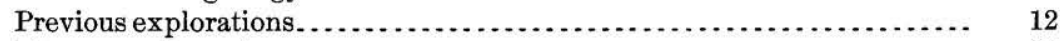

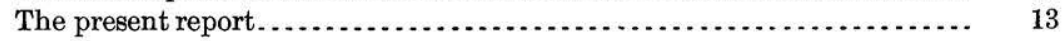

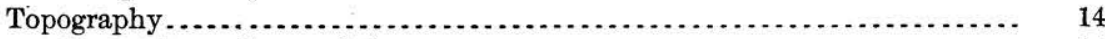

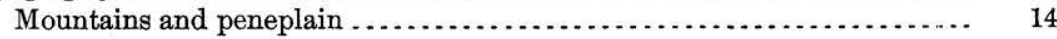

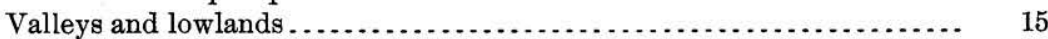

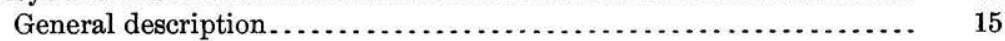

Recent changes of level . . . . . . . . . . 17

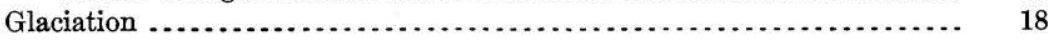

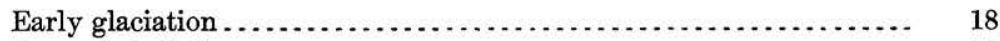

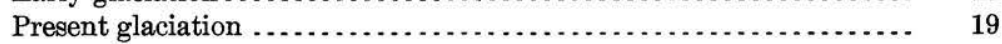

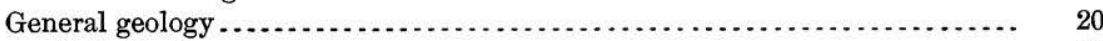

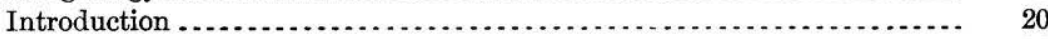

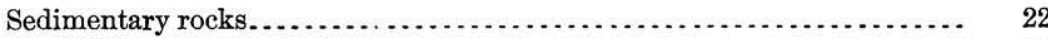

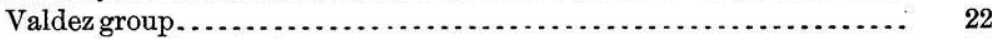

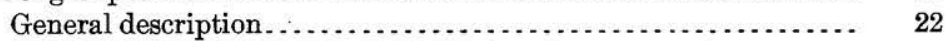

Age and correlation .................................. 23

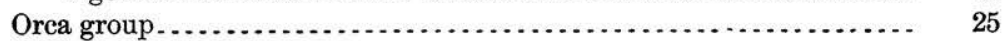

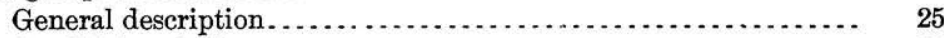

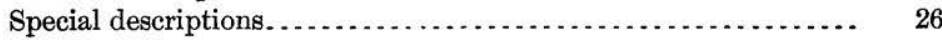

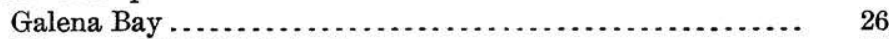

Ellamar and Bligh Island........................ 28

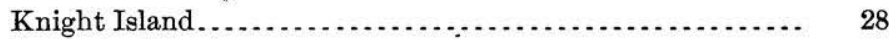

Latouche Island ................................... 29

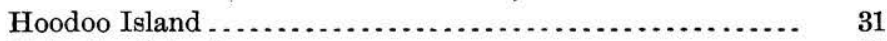

Elrington Island. ................................... 31

Age and correlation of the Orca group .................. 32

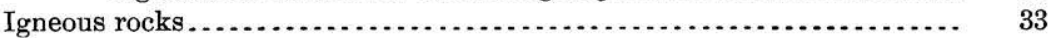

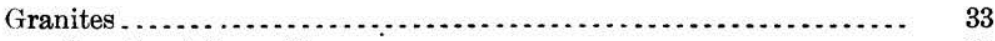

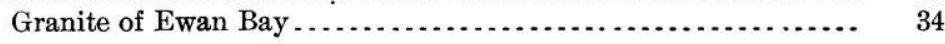

Eshamy granite ..................................... 34

Nellie Juan granite................................. 37

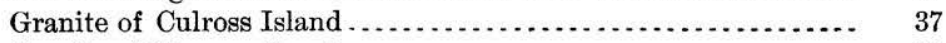

Granite of Passage Canal . . . . . . . . . . . . 38

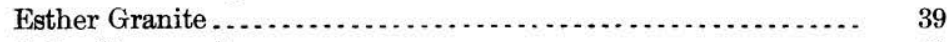

Cedar Bay granite .................................. 41

Sheep Bay granite.................................. 43

Other granite areas. . . . . . . . . . .

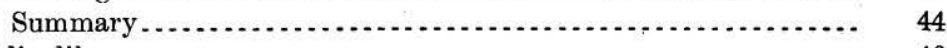

Acidic dikes ...................................... 46 
General geology-Continued. Page.

Igneous rocks-Continued.

Basic intrusive rocks.

Gabbros 49

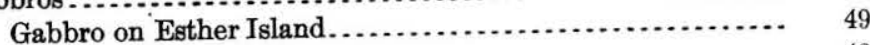

Gabbro on Latouche Island ........................ 49

Diabases................................................... 50

Diabase dikes at Valdez Narrows..................... 50

Diabase in Tatitlek Narrows. ......................... 50

Diabase on Unakwik Inlet ............................. 50

Greenstones. ............................................... 51

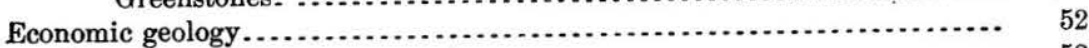

Copper

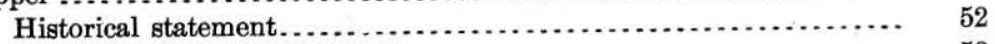

Ore minerals............................................ 53

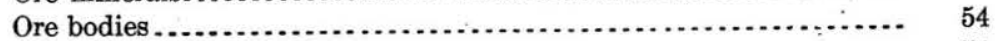

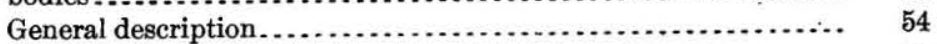

Origin of the ore bodies............................... 57

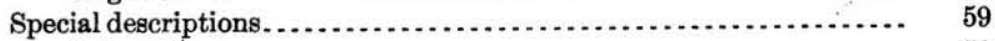

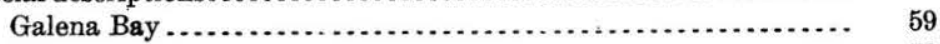

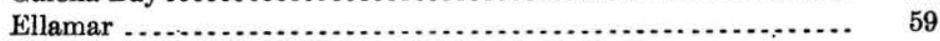

Boulder Bay . . . . 61

Landlocked Bay ........................................... 61

Standard Copper Mines Company ..................... 62

Three Man Mining Company . . . . . . . . . . . . . . $62 \ldots \ldots \ldots .62$

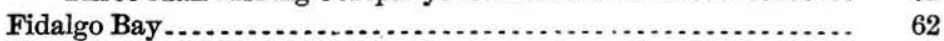

Whalen and Nelson prospect........................ 62

Fidalgo Mining Company ............................. 63

Fidalgo Alaska Copper Company ..................... 63

Latouche Island . . . . . .

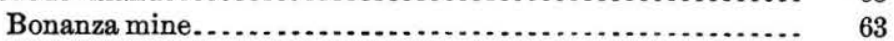

Reynolds-Alaska Development Company ............... 66

Latouche Copper Mining Company ..................... 67

Knight Island . . . . . . . . . . . . . . . . . . . . . . . . . . . 67

Knights Island Consolidated Copper Company ............ 67

Russell Ball Copper Company......................... 68

Happy Jack Copper Mining and Development Company.... 68

Copper Bullion claims ................................ 69

Knights Island Mining and Development Company........ 69

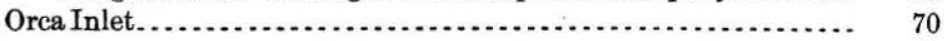

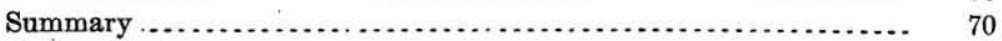

Prospecting:-

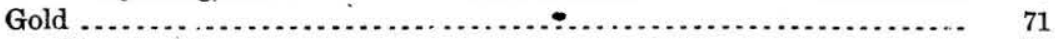

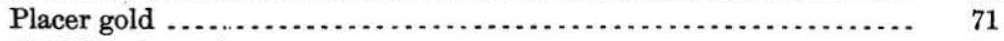

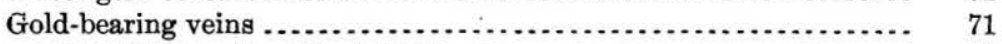

Port Valdez, by Alfred H. Brooks...................... $\quad 72$

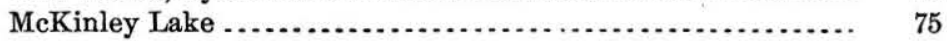

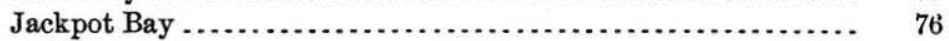

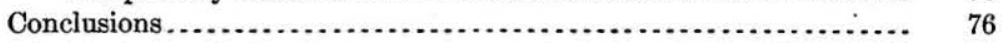

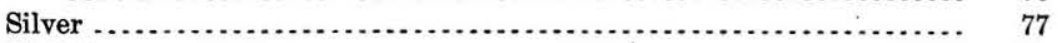

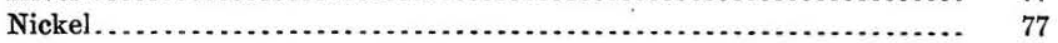

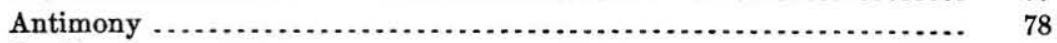

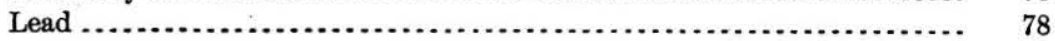


Economic geology-Continued. Page.

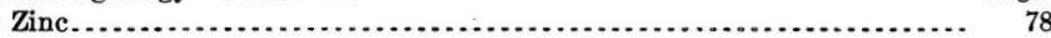

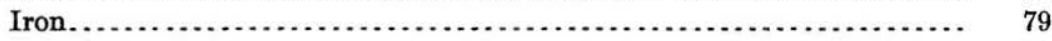

Asbestos . . . .

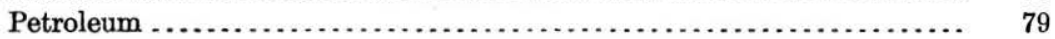

Recent Survey publications on Alaska.............................. 80

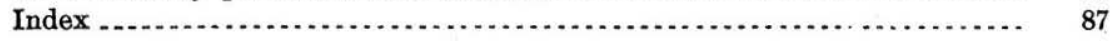




\section{ILLUSTRATIONS.}

Page.

Plate I. Sketch map of Prince William Sound .................. 10

II. Geologic reconnaissance map of Prince William Sound ........ In pocket.

III. View looking northward from vicinity of Cordova................ 14

IV. Lowland plain between Landlocked and Fidalgo bays............. 16

V. The Three Giants, Knight Island.............................. 18

VI. $A$, Glaciated mountains and fiords, Knight Island; $B$, Elevated beach, Columbia Bay ........................................ 18

VII. $A$, Slate and graywacke of Orca group, Gull Island; $B$, Slate overlain by greenstone near Rocky Point........................ 24

III. $A$, Ellipsoidal greenstone near Rocky Point; $B$, Sections of ellipsoidal greenstone near Rocky Point............................. 26

IX. Microphotographs .......................................... 36

X. $A$, Ellamar mine at Ellamar; $B$, Dock and ore bunkers of the Standard Copper Mines Company on Landlocked Bay............... $\quad 60$

XI. $A$, Quarry face of the Bonanza mine on Latouche Island; $B$, Dock, ore bunkers, etc., of the Bonanza mine on Latouche Island...... 64

XII. Topographic and geologic map of part of Latouche Island ...... In pocket.

Figure 1. Interbedding of sediments and basic lava flows, Orca group....... 27

2. Map and section of the northeast end of Latouche Island........... 29

3. Sections across Latouche Island........................... $\quad 30$

4. Plan of underground workings at the Ellamar mine, September, 1905. 60

5. Bonanza mine, Latouche Island........................... 64

6. Plan of underground workings at the Bonanza mine, June, 1909... $\quad 65$

7. Duchess tunnel, Latouche Island............................ 66

8. Bald Eagle tunnel, Knight Island......................... . 68

9. Tunnel cutting five schistose ore-bearing zones, Knight Island.... 69 


\section{PREFACE.}

By Alfred H. Brooks.

The continued progress of the copper-mining industry on Prince William Sound since the very hasty examination of this field in 1900 by Schrader and Spencer has led to a demand for further investigations. The following report is the result of reconnaissance surveys made in 1905 and in 1908, which complete the preliminary work in this district. Should the mining interests continue to develop, detailed surveys of the more important parts of the field will be undertaken as soon as circumstances permit.

Altogether a little over five months was devoted to the studies whose results are here submitted. During this time over 1,500 miles of shore line was examined and more than a hundred prospects and mines were visited, some of which were surveyed in considerable detail. Geologic reconnaissance mapping was carried over an area of about 6,000 square miles. Detailed work was also done in the northern half of Latouche Island. In view of the hasty character of the work and the intricacy of the geology it could not be expected that final results on all the many problems could be achieved. Much attention was given to studying the economic problems, to determine as far as possible the general laws governing the occurrence of the ore bodies. Incidental to this study, facts were gathered bearing on the occurrence and extent of individual ore bodies, and many of these are presented in the following pages.

Those who expect to find in this volume an exhaustive statement of the mineral occurrences on individual properties or an estimate of their extent and value will be disappointed. The preparation of such reports is the business of private mining experts, rather than of the Federal Government. It is believed, however, that this statement of the geology of the region will be of great benefit to the mining interests.

Among the important results here set forth is the presence of two unconformable rock groups, the Valdez and the Orea. Though this was suggested by the earlier investigations of this field, the definite proof was lacking. Of equal importance is the subdivision of the Orca 
group into a lower and an upper member. It seems possible that at least the lowest Orca, made up chiefly of greenstone effusives, may prove to be of the same age as the Nikolai greenstone of the Chitina basin, which it resembles lithologically. Copper ores are associated with both these greenstone formations. Another result of these studies is the evidence of very close folding accompanied by faulting to which the rocks of both the Orca and Valdez groups have been subjected.

The important fact bearing on the distribution of the ore bodies is that they appear to be found only in the rocks of the Orca group and, indeed, for the most part in close association with the greenstone member. Mr. Grant and Mr. Higgins indicate that the copper was derived from the greenstones, a genesis which is entirely similar to that of most of the copper ores of the Chitina ${ }^{a}$ and White River ${ }^{b}$ districts.

${ }^{a}$ Moffit, F. H., and Maddren, A. G., Mineral resources of the Kotsina-Chitina region : Bull. U. S. Geol. Survey No. 374, 1909, p. 51.

${ }^{b}$ Moffit, F. H., and Knopf, Adolph, Mineral resources of the Nabesna-White River districts: Bull. U. S. Geol. Survey No. 379, 1909, p. 171. 


\title{
RECONNAISSANCE OF THE GEOLOGY AND MINERAL RESOURCES OF PRINCE WILLIAM SOUND, ALASKA.
}

\author{
By U. S. Grant and D. F. Higgins.
}

\section{INTRODUCTION.}

\section{LOCATION AND GEOGRAPHY.}

Prince William Sound, formerly known by the Russians as Chugach Gulf, is an embayment extending northward from the north side of the Gulf of Alaska, near the center. The sound lies west of the Copper River delta and east of Cook Inlet, between west longitude $145^{\circ} 37^{\prime}$ and $148^{\circ} 43^{\prime}$ and north latitude $59^{\circ} 46^{\prime}$ and $61^{\circ} 16^{\prime}$. The extreme east and west length of the sound, from the head of Cordova. Bay on the east to the head of Port Nellie Juan (or Kings Bay) on the west, is 105.6 miles, and its extreme north-south dimension, from the head of College Fiord on the north to the southern extremity of Montague Island on the south, is 104 miles. (See Pls. I and II.)

Prince William Sound is not a sound according to the customary asage of that term, but is an extensive bay or gulf which includes many islands. The coast line is indented by numerous long, narrow inlets or fiords and by other less regutar embayments whose shores are commonly of great irregularity. The approximate amount of mainland shore line from the Copper River delta to Cape Puget is 975 miles, and the total shore line of the islands in the sound is nearly 1,065 miles, making the total amount of shore line on the sound approximately 2,040 miles. The coast is rugged and rocky and in many places rises abruptly from the water's edge to altitudes of 1,000 to 3,000 feet. A few miles inland from the coast are mountains from 3,000 to over 10,000 feet in altitude. Mountains uninterruptedly surround the sound on its east, north, and west sides, and the larger islands, especially Hawkins, Hinchinbrook, and Montague, which lie along the south side of the sound, are also mountainous. There are many snow fields about Prince William Sound, and from these fields glaciers descend, reaching tide water in a number of inlets or fiords on the north and west sides of the sound. 
Key to Plate I.

Copper Mines and Prospects. Ellamar district.

\section{Ellamar mine.}

3. Rua \& Frodenburg; Wagner; Falck; Schage.

4. Reynolds-Alaska Development Co.

5. Fielder \& Hemple.

6. Simonstad \& Hendrie.

7. Galena Bay Mining Co. (Millard).

9. Tibbits \& Wilson.

11. Standard Copper Mining Co. (Bourke \& Steele); Grove.

12. Hemple.

13. Reynolds-Alaska DevelopmentCo.; Spaulding;

14.) Barre.

15. Three Man Mining Co. (Dickey).

17.)

18. Dolan \& Ryström; Dolan \& Wagner.

19. Chisna Consolidated Copper Co. (Griffith).

21. Fidalgo Alaska Copper Co. (Schlosser).

22. Neversweat; Manhattan.

23. Shamrock; Arley; Bratton.

24. Merchant, Bell \& Larson; Roosevelt; Birdie.

25. Fidalgo Mining Co. (Blakney); Simonstad \&

26. Whalen \& Nelson.

27. Bratton.

27. Guthrie \& Bellola.

29. Cordov
30.
31.

Cordova district.

32. Kelly \& Macormac.

33. Flynn \& Scott properties.

34. Kippin \& Co.; Kinney; Diggs.

35. Flynn \& Co.

37. Revenue.

39. Tansey groups.

40.

41. Flynn \& Co.

42. Armstrong Exploration Co.

44. Dalton, Boswell \& Lowe.

45. Cordova Copper Co.

46. Emerald.

47. Boswell \& Lowe.

48. Rosencrans \& Co.

49. Shepard \& Macpherson; Kelly \& Van Slack; Diggs \& Tremble; Brown \& Collins; McKenna \& Kiffin; Flynn \& Co.

50. Flynn \& Co

51. Hanson \& Co.; Frynn, Holt, Brown \& Collins;

52. Kelly, Diggs, McKenna \& Tremble.

53. $\}$ Wash \& Waskey.

55. Boswell, Holt \& Flynn.

57. Ibeck, Ellis \& Boone; MeMurphy; Diggs.

58. Scott \& Ibeck.

146. Harris; Ibeck; Richards.
Cordova-Tacoma Copper Go.

Latouche Island district.

60. Latouche Consolidated Copper Co. (Tibbits).

61. Seattle-Alaska Copper Co.

62. Latouche Island Copper Mining Co. (Murphy).

64. Reynolds-Alaska Development Co.

66. Chicago-Latouche Mining and Power Co. (Ba-

67. Bonanza Mine.

69. Latouche Copper Mining Co. (Barrack).

70.

71. Hogg.

Knight Island district. 73. Happy Jack Copper Mining and Development

74. Hogan, Hemple \& Egan.

75. James Mullins Coal Co. (Wilson).

77. Kilbourn.

78. Schultz.

89. Harvey.
81. Hendrix, Reavley \& McMasters.

83. 8raham \& Harrison.

85. Bettles.

86. Sponberg, Sanberg \& Simpson.

87. Larson.

88. Ericksen \& Allen.

89. Moore.

90. Mubbard \& Elliott.

91. Russell Ball Copper Co.

92. Grove \& Walters.

93. Knights Island Copper Mining Co. (Hemple). 94. Twentieth Century Knight Island Copper Min-

95. Knights Island Alaska Copper Co.

96. Hemple.

97. Knights Island Consolidated Copper Co. (Hub-

98. bard \& Elliott).

99. Copper Bullion (Rua).

100.

101. Wallace, McPherson \& Valentine.

102. Fergusson, Johnson \& Harvey.

103. Kaczanowski \& Wilson

104. Wallace, McPherson \& Valentine.

105. Big Passage Copper Mining Co.

106. Knights Island Mining and Development Co. 108. Crown Copper Co. (Bradford).

109. Malack.

110. Boyle.

111. Malack.

112. Von Gunther.

113. Singletary.

Glacier Island district.

116. Glendinning Mining Co.

117. Byers.

119. Chamberlain.

120.

122. Nelson \& Ryström.

123. Jensen.

124. Jensen, Walace \& Kilbourn.

125. Nelson.

126. Leitzke

Seward district.

127. Pitman \& Gould.

128. Ellsworth; Reynolds-Alaska Development Co.

129. Peterson.

130. Pitman \& Gould.

132. Reynolds-Alaska Development Co.

133.

134. Likes \& Frazer.

135.)

136. Redman \& Guyot.

137. Shaw, Deubruel \& Bouchaert.

147. Bettles \& Evans.

149. - - Gold Prospects.

McKinley Lake (east of Cordova).

139. Armstrong Exploration Co.

140. Walker; Erickson Bros.; Maloney; Armstrong Exploration $\mathrm{Co}$.

141. Rice Bros.; Barclay \& Harris.

20. Benzer.

Fidalgo Bay.

145. Cliff mine.

Port Valdez.

Jackpot Bay.

114. Evans, Cooper \& Matson.

138. $\overline{\text { Gould. }}$

143. California-Alaska Mining Co.

144. Stephenson

150. Fairman \& Madsen; Gaydon.

151. Gilpatrick claims.

\section{Antimony Prospect.}

Port Wells.

115. Bratten, Daniels \& Coch.

Nickel Prospect.

148. Smith.

Unakwik Inlet. 


The principal towns of the district are Valdez and Cordova. Valdez is situated at the northeast corner of the sound, at the head of Port Valdez. From this town the government telegraph line and trail lead into the interior of Alaska, and three railways have been projected toward the Copper River district. Up to September, 1909, only a small amount of track had been laid on these railways. Valdez is the outfitting point for much of Prince William Sound and for the Copper River and Tanana districts. Cordova is situated on the southeastern part of the sound, on the southeast shore of Orca Bay. It is the tide-water terminus of the Copper River and Northwestern Railway, on which rails had been laid in September, 1909, to a distance of about 100 miles. Building was especially active at Cordova during the summers of 1908 and 1909. Other settlements are at Orca, on Orca Bay; Landlock, on Landlocked Bay; Ellamar, on Virgin Bay; and Latouche, on Latouche Island. There are mining camps at a number of points, especially on Landlocked, Boulder, and Fidalgo bays and on Knight and Latouche islands. Indian villages exist as follows: Nuchek, on the west end of Hinchinbrook Island; Tatitlek, near Ellamar; Kiniklik, on the north side of the sound between Eaglek Bay and Unakwik Inlet; and Chenega, near the southeast corner of Chenega Island. (See Pls. I and II.)

\section{OUTLINE OF THE GEOLOGY.}

The sedimentary rocks of Prince William Sound are separable into two divisions, known as the Valdez group and the Orca group. The Valdez is the older, and outcrops along the northern part of the sound, especially on the shores of Port Valdez. This group is composed of slates and graywackes which have been closely folded and metamorphosed to some extent, so that they are now partly crystallized. No markedly crystalline schists occur, except in the vicinity of granitic intrusions. The Orca group lies unconformably upon the Valdez and has been much folded, though not as closely as the Valdez. The Orca group consists in the main of dark-colored slates and graywackes, with locally much greenstone; conglomerates and inconspicuous limestones occur in some places. The greenstones are to a large extent altered basic lava flows, interstratified with slates and graywackes. The peculiar ellipsoidal structure of these greenstones is a marked characteristic of parts of the Orca group. The Orca rocks occur especially on the eastern and southern shores of the sound and on the islands of the central part of the sound. (See Pl. II.) The intrusive rocks of the district consist of basic dikes and bosses and dikes of granite. The basic dikes are apparently of Orca age, but some at least of the granites cut the Orca rocks. The age of the Valdez and Orca groups is not known; the Orca is, however, probably Mesozoic and the Valdez perhaps Paleozoic. 
The chief mineral deposits of Prince William Sound are copper ores. The ore mineral is chalcopyrite, with which pyrrhotite usually occurs. The ore deposits are mainly in shear zones in the greenstones or in the slates of the Orca group close to the greenstones. The important copper deposit on Latouche Island is, however, not known to be intimately associated with greenstone. There are two producing copper mines on the sound-the Ellamar mine, at Ellamar, and the Bonanza mine, on Latouche Island. Copper prospecting has been active, especially about Boulder, Landlocked, and Fidalgo bays and on Knight and Latouche islands.

PREVIOUS EXPLORATIONS.

Prince William Sound was discovered by Capt. James Cook in 1778. It was visited by Artega in 1779, Zaikof in 1783, Martínez in 1788, Fidalgo in 1790, Malaspina in 1791, and Vancouver in 1794, and later by other explorers. ${ }^{a}$ Vancouver made a reconnaissance of much of the sound and his maps were of value for over one hundred years. The Russians early used the sound as trading ground, and a post was established at Nuchek, on the west end of Hinchinbrook Island, about 1793. These early explorers gave geographic information concerning the district, but very little as to its geology.

The first geologic exploration of Prince William Sound was undertaken by Mendenhall ${ }^{b}$ and Schrader ${ }^{c}$ in 1898. Mendenhall gave an account of (1) explorations which had been made in the district, (2) the geography, and (3) the geology of Passage Canal and Port Wells, in the northwestern part of the sound. He described the Sunrise "series" of rocks as occupying the shores of this part of the sound and as extending westward to Cook Inlet. Schrader visited points on the eastern shore of Prince William Sound between Orca and Valdez. He described the geology and geography of that district and named the Valdez "series" and the Orca "series" of rocks. He also described the copper prospects on Landlocked Bay, at Ellamar, and on Latouche Island. His report is accompanied by a topographic map of the sound and by a topographic and geologic map of Port Valdez and the district to the northeast.

The Harriman Alaska Expedition visited Prince Wiliam Sound in 1899. The Columbia Glacier and the glaciers of College and Harriman fiords were described in detail. ${ }^{d}$ Information concerning the geology and ore deposits was obtained and the main rocks of the

a Brooks, A. H., The geography and geology of Alaska: Prof. Paper U. S. Geol. Survey No. 45,1906 , pp. 109-113.

b Mendenhall, W. C., A reconnaissance from Resurrection Bay to the Tanana River, Alaska, in 1898: Twentieth Ann. Rept. U. S. Geol. Survey, pt. 7, 1900, pp. 265-340.

- Schrader, F. C., A reconnaissance of a part of Prince William Sound and the Copper River district, Alaska, in 1898 : Idem, pp. 341-423.

${ }^{d}$ Gilbert, G. K., Harriman Alaska Expedition, vol. 3, 1904. 
sound were referred to the Vancouver "series," regarded as Lower Jurassic in age. ${ }^{a}$

Schrader and Spencer ${ }^{b}$ examined more in detail parts of Prince William Sound in 1900 and described the general geology and copper prospects. Their report is accompanied by a geologic map of the sound.

Moffit in 1907 obtained information concerning the progress of copper mining and prospecting, ${ }^{c}$ and since this report was.written Lincoln has described the Bonanza mine on Latouche Island. ${ }^{d}$

\section{THE PRESENT REPORT.}

The senior author, assisted by Sidney Paige, made a reconnaissance of the general geology and mineral resources of Prince William Sound in 1905, and this work was continued by both authors of this report during a few weeks in the summer of 1908, and they obtained some additional information in June, 1909. Preliminary reports of this work have already been published.e In this reconnaissance practically all the shores of the sound were visited with the exception of (1) Montague and Green islands, (2) the outer parts of Hawkins and Hinchinbrook islands, and (3) some of the islands in the northwestern portion of the sound. A large number of copper prospects were examined-in fact, all the important prospects and nearly all the others.

The map of the sound (Pl. II) which aceompanies this report is based on the charts of the United States Coast and Geodetic Survey, and the shores, where indicated by solid lines, are taken from the detailed surveys of that organization and from field traverses by.the authors. Where no detailed information is available the shores are shown by broken lines. The authors' traverses include Port Fidalgo, Port Gravina, and practically all of the northern and western shores of the sound and most of the adjacent islands.

In the work on Prince William Sound the Survey parties received very essential aid from mining men and prospectors and were given free access to all mines and prospects except one. The cordial cooperation of the people of the sound was of much help. Especial thanks are due to Capt. J. J. Bettles, of Valdez, whose intimate knowledge of the sound was of great assistance during each field season.

\footnotetext{
${ }^{a}$ Emerson, B. K., Palache, Charles, and Ulrich, E. O., Harriman Alaska Expedition, vol. 4,1904 .

b Schrader, F. C., and Spencer, A. C., The geology and mineral resources of a portion of the Copper River district, Alaska, a special publication of the U. S. Geol. Survey, 1901.

- Moffit, F. H., Notes on copper prospects of Prince William Sound: Bull. U. S. Geol. Survey No. 345,1908 , pp. 176-178.

"Lincoln, F. C., The Big Bonanza copper mine of Latouche Island, Alaska: Econ. Geology, vol. 4, 1909, pp. 201-213.

- Grant, U. S., Copper and other mineral resources of Prince William Sound: Bull. U. S. Geol. Survey No. 284, 1906, pp. 78-87. Grant, U. S., and Higgins, D .F., Copper mining and prospecting on Prince William Sound, Alaska, 1908 : Bull. U. S. Geol. Survey No. 379, 1909, pp. 87-96. Grant, U. S., Gold on Prince William Sound, Alaska: Idem, p. 97.
} 
TOPOGRAPHY.

MOUNTAINS AND PENEPLAIN.

As the St. Elias Range extends northwestward from Mount St. Elias it divides into subordinate ranges, the southern one of which is called the Chugach Mountains. West of Copper River the axis of the Chugach Mountains trends a little north of west, runs roughly parallel with the northern shore of Prince William Sound, and then bends suddenly to the southwest and forms the backbone of Kenai Peninsula. The continuation of the same mountains to the southwest is indicated by a few small islands in the entrance to Cook Inlet, and the mountains themselves reappear on Afognak and Kodiak islands. The Chugach Mountains nearly surround Prince William Sound. In fact, the sound lies in this mountain range, but to the south of its main axis. The sound is thus a highly eroded part of the Chugach Mountains into which the sea has come.

On the south the altitude of the mountain tops is much lower than on the north and northwest, where the highest peaks occur along the axis of the range. About Cordova the mountains are 2,000 to 2,500 feet above sea level; north of Cordova Bay they rise to 3,500 feet or higher. (See Pl. III.) On Elrington and Latouche islands, at the southwestern entrance to the sound, the mountains rise to about the same altitudes (1,500 to 2,000 feet), but they are higher at intermediate points-for example, on Montague Island. The general altitude of the mountains on this island is probably 3,500 to 4,500 feet, but accurate figures are not available. North of Fidalgo Bay the general height of the mountain tops is 2,500 to 3,000 feet; two peaks here which rise higher than the others are Copper Mountain, 3,830 feet, and Mount Denson, 5,886 feet. South of Port Valdez heights of 3,500 to 4,500 feet are common, and north of Port Valdez altitudes of 4,500 to 6,000 feet are reached. Still farther north, along the main axis of the range, elevations of over 7,000 feet are reported. Still higher peaks along this axis are known; one about 30 miles north of the tide-water terminus of the Columbia Glacier rises to 11,190 feet, and three peaks which are 7,500 to 8,200 feet in height occur between the heads of Harriman Fiord and Passage Canal of Prince William Sound and Turnagain Arm of Cook Inlet. A peak near the west side of College Fiord is 8,046 feet in height; two others, a few miles north of Harriman Fiord, rise to approximately 10,000 feet, and north of these two is at least one still higher peak.

Viewed from the water near their bases these mountains appear very irregular in altitude, but when seen from some high peak or from a distance of 10 miles or more across the water the mountain tops appear to rise to the same general altitude. The fairly accordant tops of these mountains composed of highly folded strata thus 


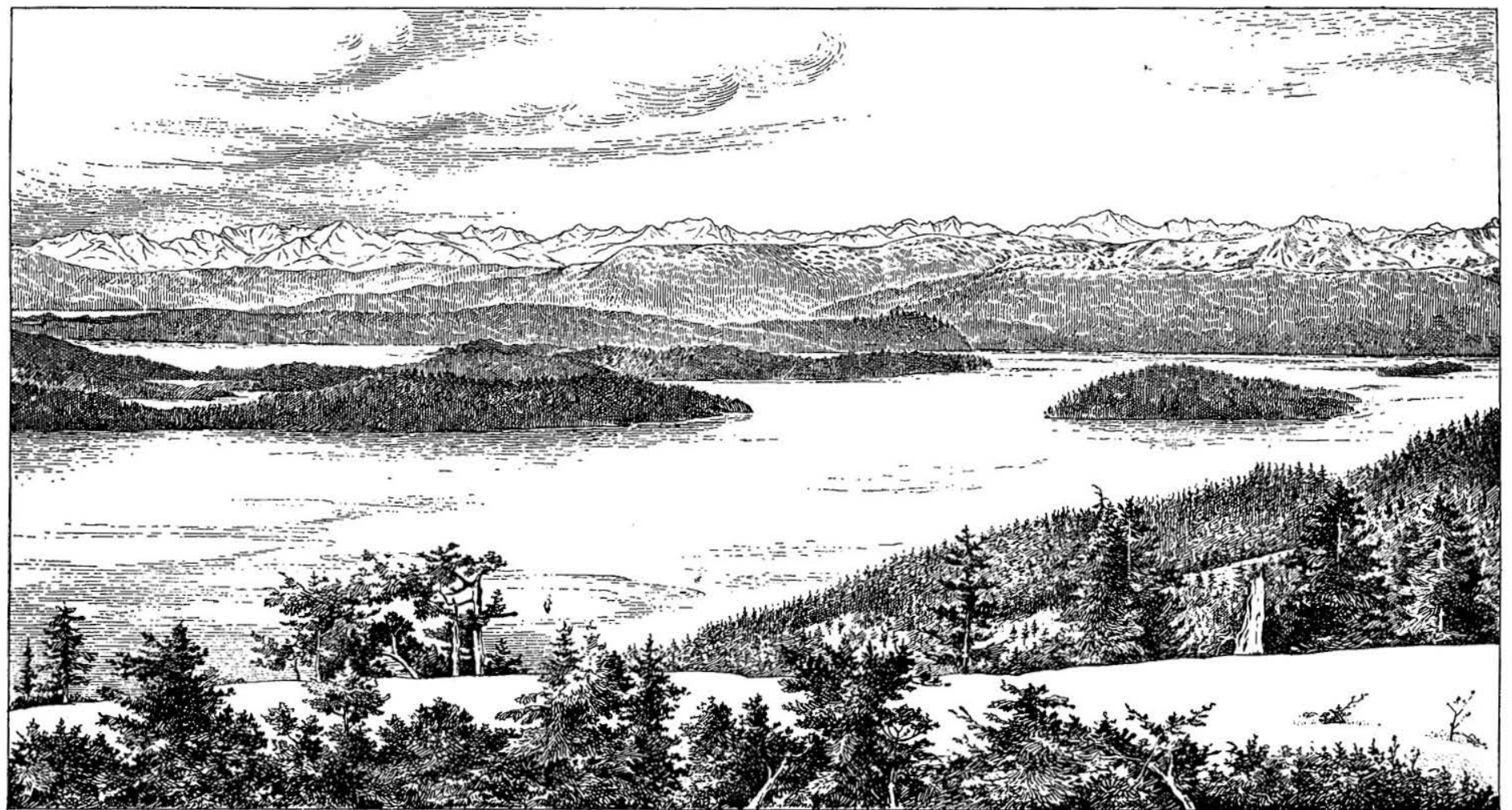

VIEW LOOKING NORTHWARD FROM VICINITY OF CORDOVA,

Shows the general character of the mountains about Prince William Sound and their accordant summits. The mountains in the foreground are glaciated; the summits of those in the background are unglaciated. Photograph by Hegg. 

suggest an ancient peneplain which has been raised far above sea level, warped, and highly eroded. This erosion has been so complete that no extensive remnants of the old peneplain appear about Prince William Sound, and in places, especially in the central part of the sound, all traces of this old surface have disappeared. The warping brought up the peneplain to its highest point along the axis of the Chugach Mountains, from which the old plain slopes southward toward the sea. Minor slopes descend from the east and the west toward the center of the sound.

These accordant mountain tops can be seen to the north of Orca Bay, when viewed from elevations near Cordova. (See Pl. III.) They are also fairly well developed on Hinchinbrook Island, and are especially marked on Montague Island when viewed from the northern part of Latouche Island or from the vicinity of Point Countess, about 20 miles northwest of Montague Island. On the west side of Port Bainbridge the mountains on the north rise to about 3,000 feet and become lower on the south toward Point Puget, near which they are about 2,000 feet above sea level.

\section{VALLEYS AND LOWLANDS.}

GENERAL DESCRIPTION.

The topography of Prince William Sound is that of a maturely eroded mountainous district with the forms of river erosion modified by ice erosion. Into such a district the sea has come, filling the main basin of the sound and extending far up the valleys that lead into it. The main valleys when the district was all above sea level probably ran southward, possibly one to the east and another to the west of Montague Island, while tributary streams came in from the northwest and northeast.

Many of the valleys as they exist to-day are of the fiord type, especially in the northern and northwestern parts of the sound, the fiord character not being so prominent in the eastern part. Among the fiords may be mentioned Port Valdez and Port Wells, the latter with two fiord arms. The main stretch of Port Valdez is about 14 miles in length and 3 miles in width. Its depth is from 600 to more than 800 feet. Soundings in Port Wells are not available. The deepest known part of the sound stretches north-northeast, between Knight and Chenega islands, from Point Countess toward the entrance to Unakwik Inlet. In this stretch are soundings of more than 1,800 feet, and just east of Long Island one of 2,460 feet has been made.

The relation of some of the valleys to geologic structure is marked. The axis of Port Valdez practically coincides with the strike of the graywackes and slates along its sides, and the depression in which this fiord lies is probably cut in the more easily eroded slates. $58668^{\circ}-$ Bull. $443-10-2$ 
The main body of Jackpot Bay, west of Chenega Island, has cliffs of resistant graywackes along its sides, but the axis of the bay shows outcrops of softer slates, to which the location of the bay is undoubtedly due. The southeastern arm of Port Nellie Juan is also parallel to the strike of the surrounding rocks. Tatitlek Narrows, between Bligh Island and Ellamar, lies in an easily eroded belt of black slates, and the long, narrow island in this passage is composed of a more resist. ant dike of diabase. Latouche, Elrington, and Hoodoo islands and the passages between them lie along the general strike of the rocks of these islands. It is quite likely that the long axis of Montague Island is also parallel with the general trend of the rocks composing that island.

The most marked valley in this region is that which extends from the head of College Fiord through Port Wells, Cochrane Bay, and the upper stretch of Port Nellie Juan. This is a distance of 56 miles at sea level, and the depression is continued for an unknown distance to the northeast in the valley in which lies the Harvard Glacier, and also an unknown distance to the southwest of the head of Port Nellie Juan.

The effect of faults in locating depressions is not so evident, as such displacements in strata of uniform lithology are not easy of determination. The axis of Jack Bay, however, seems to have been determined by a fault. The abrupt change in direction of Port Valdez at its west end, with the fact that high mountains occur directly to the west of the main part of this inlet, perhaps indicates a fault; and it is possible that the inlet itself lies in a down-faulted block or graben, but the evidence for this, aside from the topography, is not at hand. The straight and deep channel which runs southeastward from the mouth of Icy Bay and cuts in a nearly straight line across Point Countess and the northeast ends of Bainbridge, Fleming, Hoodoo, and Latouche islands suggests a down-faulted block.

At a number of places in the eastern part of Prince William Sound there are fairly flat, low-lying islands, forelands, and valleys from which the mountains as a rule rise steeply. These flats are regarded as parts of an erosional surface which was developed not far above the present sea level. In height this surface is commonly 20 to 60 feet above tide, and there are a considerable number of areas which do not exceed 100 feet in altitude. Islands of this character, which have remarkably level surfaces, occur close to Rocky Point near the entrance to Galena Bay; and the Porpoise Rocks, near Nuchek, at the west end of Hinchinbrook Island, are also of this nature. The islands north and west of Bligh Island are likewise low. The lowland about the village of Tatitlek, south of Ellamar, belongs with this plain, as do also the forelands of Sheep and Bomb points, on the north side of Cordova Bay, and parts of the north side of Hinchinbrook Island. 


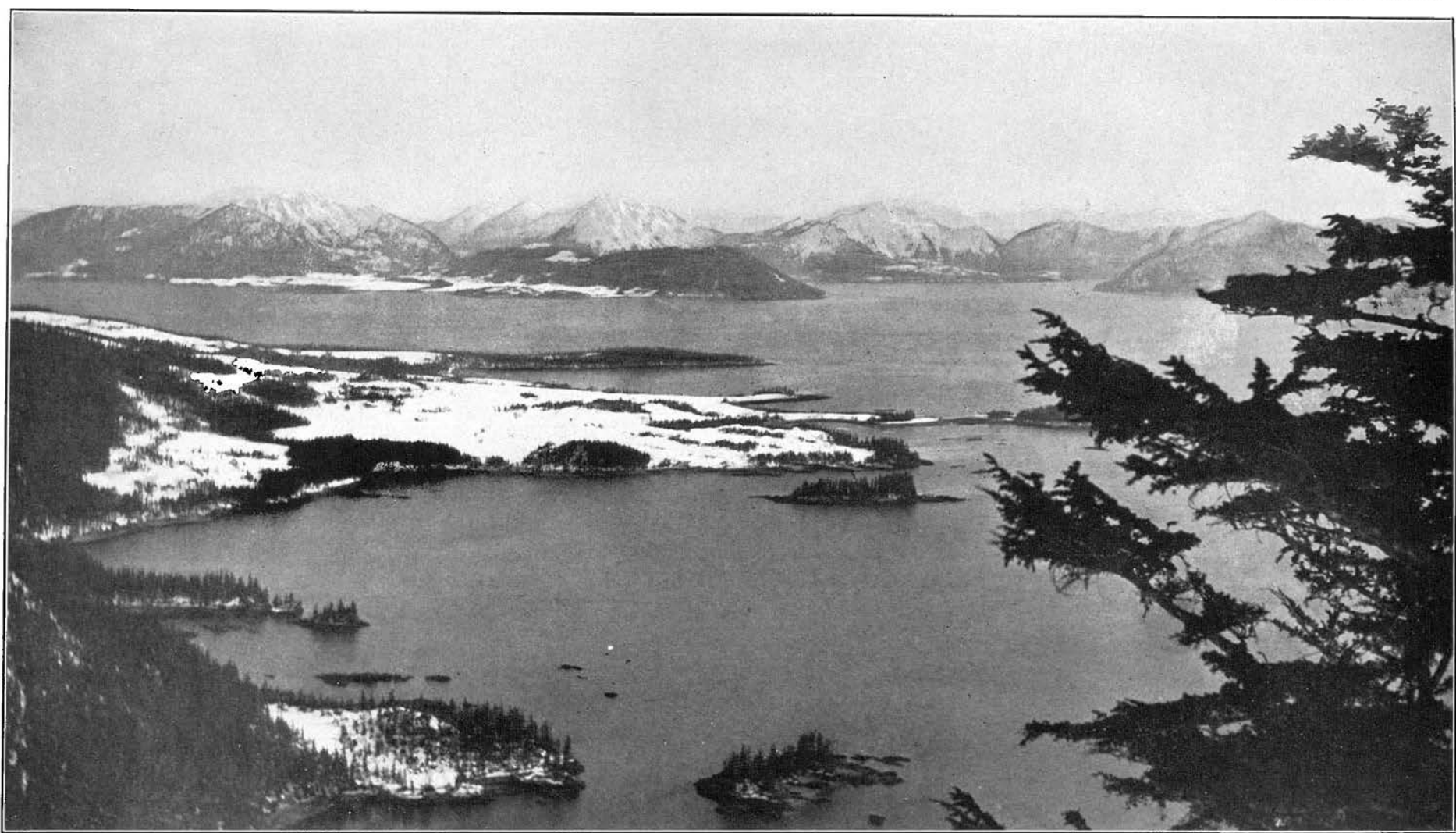

LOWLAND PLAIN BETWEEN LANDLOCKED AND FIDALGO BAYS

Lookıng toward Bowie Bay from the south slope of Copper Mountain. Photograph by Cantwell. 

One of the most characteristic forelands is the end of the point separating Landlocked and Fidalgo bays. This is shown in Plate IV. Among the valleys whose floors probably belong to this same plain is that extending from Boulder Bay northward to Galena Bay, also the valley running southward from Snug Corner Cove toward Knowles Head and the two valleys running southward from Bowie Bay.

This flat surface was examined in two places, one near Rocky Point and the other just east of Nuchek. The upturned strata were found to be beveled across by the plain, and the surface of the rocks was, in places, striated and covered by till. These features are probably also characteristic of the lowlands where not examined in detail. The plain, then, is clearly earlier than the last glaciation of the district and is thought to be a partial peneplain which has later been smoothed over by glacial ice. Some parts of the plain, especially the islands and the forelands, may have been cut by wave erosion, but this would not be the case for the valleys and for some protected points. This plain was noted by Schrader and Spencer, ${ }^{a}$ and a similar plain has been described by Gilbert ${ }^{b}$ in southeastern Alaska.

\section{RECENT CHANGES OF LEVEL.}

This lowland surface was not noted on the west side of Prince William Sound. If it exists there it is now probably below sea level. In fact, there is evidence pointing to the recent depression of the shore line in certain places in the western part of the sound. At one point on the east shore of Knight Island tundra with tree roots was found covered by all but the lowest tides. On the south side of the same island, about a mile west of Point Helen, is a storm beach built across the mouth of a small cove and in this cove the high tide runs up among the trees and has killed large numbers of them. A similar phenomenon, but less marked, is seen in a small cove on the west side of Latouche Island, three-fourths of a mile southwest of Horseshoe Bay. The shallow water known as Dangerous Passage, between Chenega Island and the mainland, is possibly due to the recent depression of the lowland surface already described.

On Port Gravina and between Sheep and Simpson bays there has been a very noticeable recent depression of the shore line. At the latter locality, near the head of a small cove, the tundra extends below high tide, and in this tundra are deat trees whose roots are covered at high tide. There has been a depression of at least 4 feet, and probably more, at this locality. On the southeast side of Port Gravina

${ }^{a}$ Schrader, F. C., and Spencer, A. C., The geology and mineral resources of a portion of the Copper River district, Alaska, a special publication of the U. S. Geol. Survey, 1901. pp. 75-76.

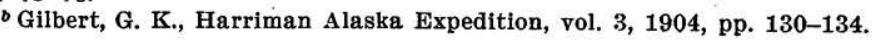


there are large numbers of dead trees killed by the high tides, and near the head of a small bay opposite the native settlement (Parsha's) tundra holding tree roots is being cut into by the waves and extends down almost to low tide, this indicating a depression of at least 10 feet.

At certain points on the sound there has been a recent elevation of the shore line. One such locality is Columbia Bay, on which old beach lines, 3 to 5 feet above present high tide, occur at several places, especially in a small bay on the east side of and 1 mile northeast of the eastern entrance to Columbia Bay. Here there is a platform, 5 feet above present high tide, with a small sea cliff at the landward side. On this platform are still standing dead trees a foot in diameter, and with these is a live spruce 4 inches in diameter, which has grown since the platform was elevated above sea level. About 6 inches of tundra has formed on this platform and is now being cut into by the present waves, thus indicating at least a slight depression since the period of elevation. Plate VI, $B$, shows this elevated beach.

\section{GLACIATION.}

All about Prince William Sound are striking evidences of glaciation. Smoothed and striated rock surfaces, roches moutonnées, hanging valleys, U-shaped valleys, fiords, etc., are seen everywhere except in parts of the higher mountains. Extensive deposits of till and glacial gravels are not common, the district being one of glacial erosion rather than of glacial deposition. The glaciated surfaces, while smooth in detail, are commonly very irregular. This is especially the case where underlying rocks are surface greenstones, a terrane which gives rise to irregular shore lines and diversified topography. On Knight Island, which is made up mainly of these greenstones, this Irregularity of shore line and of surface is marked, and Plate VI, A, shows such a typical surface as well as the irregular fiord-like character of the shore.

\section{EARLY GLACIATION.}

During comparatively recent geologic time, the Pleistocene or even later (for eviderices of this glaciation are exceedingly fresh, having hardly been touched by erosion in this district of heavy rainfall), an extensive ice sheet covered the district embracing Prince William Sound. The ice filled in all of the sound and rose high up on the flanks of the mountains. The direction of movement of this ice sheet was toward the south or southwest, but much evidence of this movement was obliterated in the later stages of glaciation by ice tongues moving down the valleys, and the striæ seen to-day are in the main those made by these local tongues of ice. The edge of the ice sheet probably was bordered.by the sea out beyond the present shore line, 


$$
\text { xe, }
$$





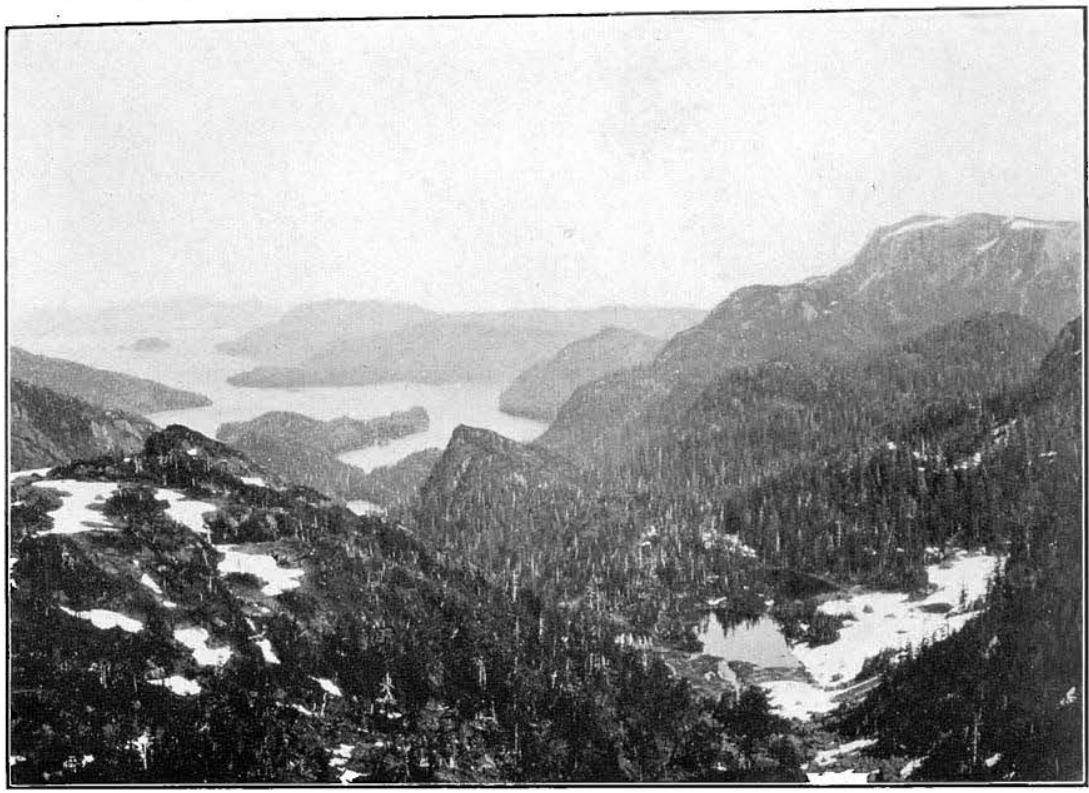

A. GLACIATED MOUNTAINS AND FIORDS, NORTH END OF KNIGHT ISLAND.

Looking north along Louis Bay. The topography is typical for districts underlain by greenstones of the Orca group.

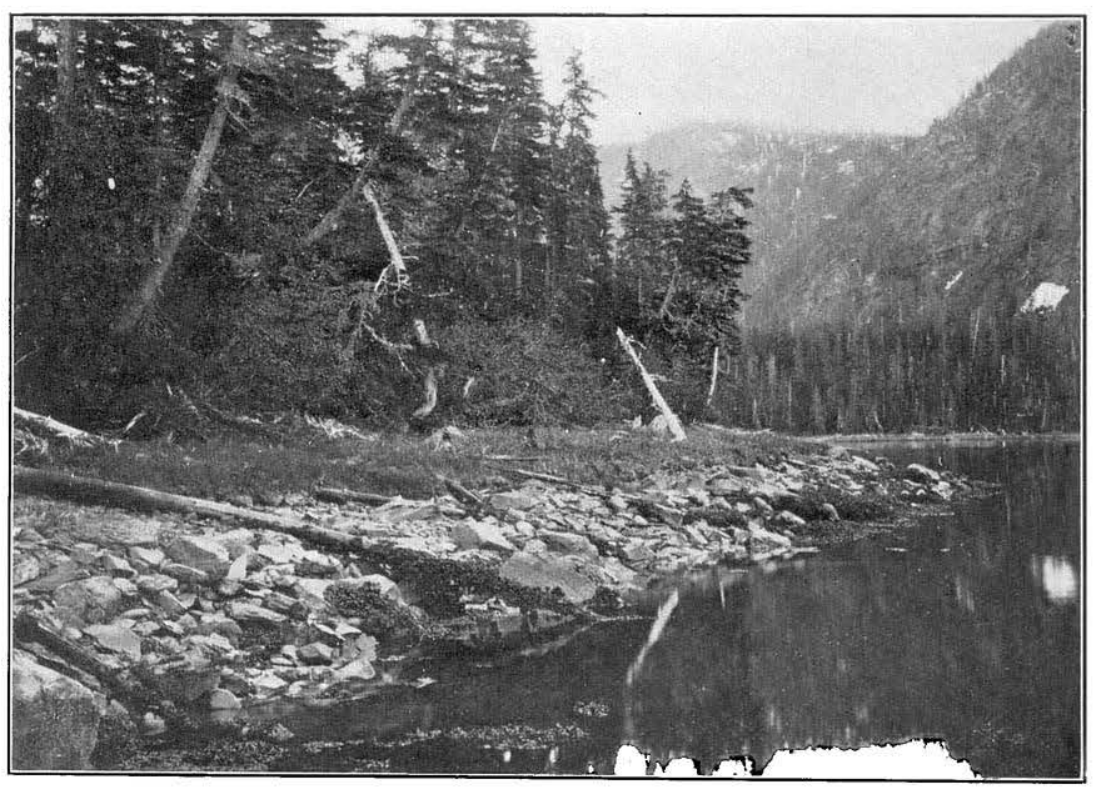

B. Elevated BEACH, GLACIER Bay. 

for the mountains at the south end of Elrington Island and those on Hinchinbrook Island are rounded by glaciation. The outer side of Montague Island has not been examined, but it is very probable that this also has been glaciated.

The height to which the ice rose above the present sea level varies somewhat, increasing toward the north. About Orca this smoothing of topography goes up to 2.300 feet. and north of Cordova Bay it reaches 2,500 feet. (See Pl. III.) Just northeast of Ellamar is a mountain whose peaks, from north to south, are respectively 1,616 , $2,068,3,044,2,068,2,145$, and 2,065 feet in height. All these peaks are rounded by glaciation except the highest, the upper 200 feet of which was possibly not glaciated. (See Pl. X, A.) On the south side of Port Valdez glaciation extends up to about 3,200 feet. On the west side of the sound the limit of glaciation is a little lower than on the east side as noted above. About Port Bainbridge the rounded slopes extend up to approximately 2,000 feet. On Elrington and Latouche islands the peaks rise to over 2,000 feet and are glaciated nearly or quite to their summits. Among the highest peaks on Knight Island are three known as the Three Giants, just south of the extreme east end of Drier Bay. The tops of these peaks are sharp and not glaciated; the smoothing by the ice extends up to about 2,400 feet. (See Pl. V.)

After the main ice sheet became much reduced in size local glaciers did much to continue the work of glacial erosion, and practically all the valleys reaching into the sound carried glaciers. There was at this time in certain places active cutting back of cirque heads and consequent sharpening of the topography, in some localities below the former maximum height of glaciation. Such cirque action was prominent on Latouche Island, on whose northwestern slope several well-marked.cirques can now be seen. One of these cirques lies just back of Horseshoe Bay and another just back of Wilson Bay. (See Pl. XII.) One of the most typical cirques is near the south end of the island, southeast of Montgomery Bay. These all face toward the northwest.

\section{RECENT GLACIATION.}

The conditions just noted above gradually changed until most of the valleys became free of ice and present conditions were established. There are now a large number of alpine glaciers about the shores of the sound and on Montague Island. Most of these glaciers do not reach sea level, but about the north and west shores of the sound there are still several extensive ice fields, from which ice tongues move down to sea level. The locations of these are shown on Plate II. The most numerous glaciers are about the two arms of Port WellsCollege and Harriman fiords_-and the largest glacier on the sound 
is the Columbia, at the head of Columbia Bay. This magnificent glacier has a semicircular front of about 4 miles, most of which is along tide water. About $2 \frac{1}{2}$ miles of this front is a nearly vertical ice cliff approximately 400 feet in height. ${ }^{a}$

\section{GENERAL GEOLOGY.}

\section{INTRODUCTION.}

The rocks of Prince William Sound are readily separable into those of sedimentary and those of igneous origin. To the igneous division belong (1) granites, (2) acidic dike rocks, (3) basic intrusive rocks, and (4) basic surface flows. The granites, which are mainly biotite granites, occur in several masses, the largest of which is that of Esther Island. They are intrusive into the surrounding rocks, which they have metamorphosed much less than is customary in areas of granitic intrusions. The granites are of later date than the Valdez group and are, in one case at least-that of the Sheep Bay granite-later than the Orca group. The acidic dikes are mainly aplitic in character, are not numerous, and are of small size. Dikes of quartz porphyry are known at two localities, on Unakwik Inlet and in the nunatak of the Columbia Glacier. The aplite dikes cut the Valdez group and the quartz porphyry is perhaps later than the Orca. The basic intrusives are diabases, gabbros, and diorites; some of these are intrusive into the Orca rocks. Gabbro occurs in small amount and is known at two localities, on the northeast end of Latouche Island, where it intrudes the Orca sediments, and on Esther Island, where it is associated with granite. Diorite occurs as a phase of some of the granites, especially that on Culross Passage. Dioritic rocks also occur as alteration phases of diabase and gabbro. The basic flows are commonly altered green igneous rocks, and are conveniently grouped under the name of greenstone. They are in many places ellipsoidal in character; that is, they consist largely of more or less spherical masses which vary from a few inches to 10 feet in diameter. (See Pl. VIII.) With these flows are dikes and also sills, but they are subordinate in amount and are not always easily recognized. The basic flows belong to the lower part of the Orca group and are so intimately interstratified with the sediments of that age that they may readily be considered, in structural discussions, as a part of that group.

The sedimentary rocks of the sound show marked uniformity in lithology. They are mainly slates, gray to black in color, and graywackes. The latter term is used to include sediments of coarser grain

\footnotetext{
a Some of the glaciers of Prince William Sound have been described by G. K. Gilbert (Harriman Alaska Expedition, vol. 3, 1904, pp. 71-97). The present authors expect to submit a separate paper dealing with these glaciers.
} 
than the slates, which closely resemble each other. The rocks vary, however, from graywackes to arkoses and even to sandstones and quartzites, but the term graywacke conveniently covers the whole. The sedimentary rocks are essentially without fossils and are in general closely folded, but not highly metamorphosed. The slates and graywackes alternate in thin beds, as shown in Plate VII, $A$, and such exposures are common over long distances. There is in much of the region no segregation of these rocks into a graywacke and a slate division. An exception to this statement'should be made for parts of the western shores of the sound, where the rocks are mainly graywackes, with only very subordinate amounts of slate.

Because of the uniform lithology of the sedimentary rocks of the sound, and because of their close folding and lack of fossils, it has been difficult to separate these rocks into different formations or even into different groups. Such results can be accomplished only by detailed mapping, which is not possible in a reconnaissance survey. The results here presented should therefore be regarded as partly tentative, and the mapping is also of that nature. That the sedimentary rocks of Prince William Sound are separable, however, into two unconformable series is clear. That there are more than two series is possible, but the evidence on this point is elusive. The two divisions of the sedimentary rocks of the sound are the Valdez and the Orca groups, the latter lying unconformably on the former. At the base of the Orca there is locally a conglomerate of well-worn pebbles, which are in some localities graywacke and slate set in a matrix of graywacke; with the conglomerate are bands of graywacke and slate closely similar to the rocks which form the pebbles. In such localities only the most detailed work can surely determine to which formation certain beds belong.

The main structural and historical features of the district may be briefly outlined. The Valdez rocks are the oldest. Their base and the rocks on which they lie have not been recognized in this region. The Valdez rocks were elevated, folded, eroded, and depressed before the deposition of the Orca rocks. It is probable that during the Orca deposition the land area from which the sediments were derived stood to the north, and that the coast line was much farther toward the axis of the Chugach Range than at present. Later more folding took place, accompanied by elevation of the Chugach Mountains, which now sweep into a broad curve about the north and west sides of the sound. In this period of folding and elevation the sound district had impressed upon it a broad synclinal structure, and the later erosion left the young rocks in the center of the district and the older rocks on the outside - that is, to the north and west. It is probable that this synclinal structure became more pronounced by further sinking of the land, which brought the ocean into the sound. This 
belted arrangement of the two groups of rocks is evident from an inspection of the geologic map (Pl. II).

SEDIMENTARY ROCKS.

VALDEZ GROUP.

GENERAL DESCRIPTION.

The Valdez group was named by Schrader, ${ }^{a}$ who studied these rocks about Port Valdez and to the north and east. Lithologically the group consists of slates and graywackes, commonly in narrow alternating bands. These rocks have been partly recrystallized and in places should be called schists, but, except for those in the immediate neighborhood of the intrusive masses, the terms graywacke and slate give a more accurate idea of the general character of these rocks. The graywackes still show their original angular grains, but the cement in which these grains lie has usually been recrystallized to a mass of fine-grained muscovite, chlorite, and quartz, and the whole rock has been rendered somewhat schistose. The slates vary from black, apparently carbonaceous rocks to those which are gray in color. As a rule they do not show the perfect cleavage of roofing slates, and in places they have macroscopic muscovite scales. These are the characters of the Valdez rocks about Port Valdez, their type locality. On the north and west sides of the sound they are less metamorphosed and consist in large part of massive graywackes. Stretched conglomerates were noted in this group by Schrader. ${ }^{a}$ In the vicinity of granitic intrusive rocks biotite has been extensively developed in the slates and graywackes and in a few places nodular schists, or "knotenschiefer," occur. No contemporaneous igneous rocks have been found in the Valdez group, but a few green schistose bands in the slates on the south side of Port Valdez, a mile and a half west of Fort Liscum, resemble fine water-laid tuffs.

North of Port Valdez this group of rocks extends to the northern shores of Lake Klutina, a distance of some 50 miles. On the east they extend to Copper River and up that stream to the mouth of the Chitina. South of the entrance to Port Valdez the Valdez rocks occupy the shores of Jack Bay and of the eastern part of Galena Bay, east of which their southern limit runs north of Copper Mountain. They possibly reach Fidalgo Bay, but from present knowledge this bay is thought more probably to lie in the Orca group. On the west side of Valdez Narrows, opposite the mouth of Jack Bay, the Valdez rocks are replaced for several miles by the slates and greenstones of

\footnotetext{
a Schrader, F. C., A reconnaissance of a part of Prince William Sound and the Copper River district, Alaska, in 1898: Twentieth Ann. Rept. U. S. Geol. Survey, pt. 7, 1900, p. 408 .
} 
the Orca group, but the older group reappears northeast of Point Freemantle and from this point westward and southward to Port Bainbridge forms with some granite masses the main shore line of the sound.

Structurally the Valdez rocks are closely folded, the closeness of the folds and the metamorphism of the rocks increasing to the north as the axis of the Chugach Range is approached. On the south side of Port Valdez the rocks are very closely folded into a series of anticlines and synclines which are overturned to the south, thus giving monoclinal dips of $50^{\circ}$ to $70^{\circ} \mathrm{N}$. The cleavage along the south shore of Port Valdez has commonly the same strike and within a few degrees of the same dip as the bedding. On the north shore of Jack Bay the rocks are thrown into close folds, overturned toward the south-southeast, whose axes pitch toward the west-southwest. On the south side of the bay the strike is west-northwest, practically parallel to the trend of the axis of the bay, and the dip is steeply to the north. This relation seems to be due to a fault running along the axis of the bay, and a small fault parallel to this general direction has been noted on the north side of the bay just north of the end of the point which divides the bay into two arms. The continuation of this fault is thought to account for the bringing in of the Orca group on the west side of Valdez Narrows; at this place the south side of the fault is the downthrown side.

From Point Freemantle westward to Esther Island the rocks along the headlands which separate the indentations in the coast line are, with the exception of granite, graywackes, and slates. These are in many places highly brecciated.

\section{AGE AND CORRELATION.}

Fossils have been found in the Valdez rocks in only one locality. This occurrence is described as follows: ${ }^{a}$

Plant remains, consisting, according to Mr. F. H. Knowlton, of bark or stems, were collected from Point Lowe, in the southwest part of Port Valdez, but unfortunately were without character and too greatly altered for determination.

The exact age of the Valdez rocks is not known. They have been assigned provisionally to several horizons, from Silurian to Tertiary, in the geologic column. ${ }^{b}$ From their investigations in the

\footnotetext{
a Schrader, F. C., A reconnaissance of a part of Prince William Sound and the Copper River district, Alaska, in 1898 : Twentieth Ann. Rept. U. S. Geol. Survey, pt. 7, 1900, p. 409 .

Schrader, F. C., op. cit., p. 409. Schrader, F. C., and Spencer, A. C., The geology and mineral resources of a portion of the Copper River district, Alaska, a speclal publication of the U. S. Geol. Survey, 1901, pp. 36-37. Mendenhall, W. C., Geology of the central Copper River region, Alaska: Prof. Paper U. S. Geol. Survey No. 41, 1905, pp. 32-33. Brooks, A. H., The geography and geology of Alaska: Prof. Paper U. \$. Geol. Survey No. 45,1906 , pp. 228-230.
} 
Copper River region, where the Valdez rocks appear to be older than limestone and greenstone ${ }^{a}$ assigned to the Carboniferous, Schrader and Spencer ${ }^{b}$ thought that the Valdez rocks were possibly older than the Silurian. The Valdez group lies unconformably below the Orca group, in which fossils of probable Lower Jurassic age have been found. Present knowledge indicates the probability that the Valdez group should be referred to the Paleozoic, but its exact horizon in that era is unknown.

The relation of the Valdez group to the Sunrise "series" has also been a matter of some uncertainty. The Sunrise "series" has been described by Mendenhall, ${ }^{c}$ Moffit, ${ }^{d}$ and Paige and Knopf. ${ }^{e}$ The Sunrise rocks are very similar in lithology to those of the Valdez group, and they occur in typical development about the shores of Passage Canal, in the northwestern part of Prince William Sound. They have been described as extending from this place westward to Turnagain Arm of Cook Inlet, northward from Turnagain Arm to Matanuska River, and southward from Turnagain Arm to Resurrection Bay, thus forming the eastern and central parts of Kenai Peninsula. As a rule the Sunrise rocks are a little less metamorphosed than the Valdez rocks about Port Valdez, but no break has been discovered between the Sunrise and the Valdez. In fact, it appears that the Valdez rocks on Port Valdez can be traced westward along the north shore of Prince William Sound to Passage Canal, the type locality for the Sunrise "series." It thus seems that the Valdez and the Sunrise, as first described, are the same; and consequently rocks to which the term Sunrise has been applied about the western part of the sound are here mapped as Valdez. The published descriptions of the Sunrise "series" mention conglomerates, and rocks referred to the Orca group ${ }^{f}$ have recently been discovered on the east side of Resurrection Bay. It thus seems that the Sunrise "series," though in the main equivalent to the Valdez group, probably contains some areas of Orca age.

\footnotetext{
a This limestone has since been proved to be of Triassic age, but the greenstone may be Carboniferous.

${ }^{b}$ Loc. cit.

- Mendenhall, W. C., $\dot{A}$ reconnaissance from Resurrection Bay to the Tanana River, Alaska, in 1898: Twentieth Ann. Rept. U. S. Geol. Survey, pt. 7, 1900, pp. 305-307.

${ }^{d}$ Moffit, F. H., Gold fields of the Turnagain Arm region: Bull. U. S. Geol. Survey No. 277,1906, pp. 17-19.

- Paige, Sidney, and Knopf, Adolph, Geologic reconnaissance in the Matanuska and Talkeetna basins, Alaska : Bull. U. S. Geol. Survey No. 327, 1907, pp. 12-16.

$f$ Grant, U. S., and Higgins, D. F., Notes on the geology and mineral prospects in the vicinity of Seward, Kenai Peninsula: Bull. U. S. Geol. Survey No. 379, 1909, pp. 98-107.
} 


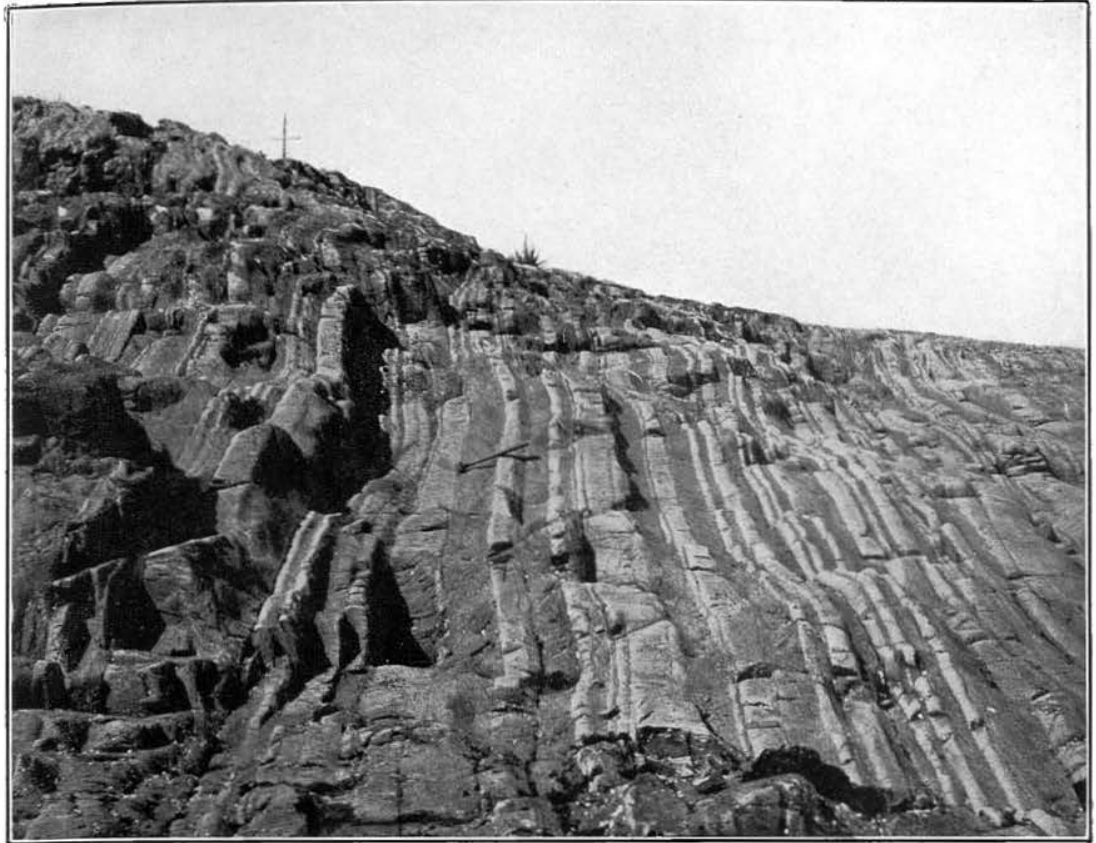

A. SLATE AND GRAYWACKE OF THE ORCA GROUP, GULL ISLAND.

The lighter-colored, more resistant layers are graywacke.

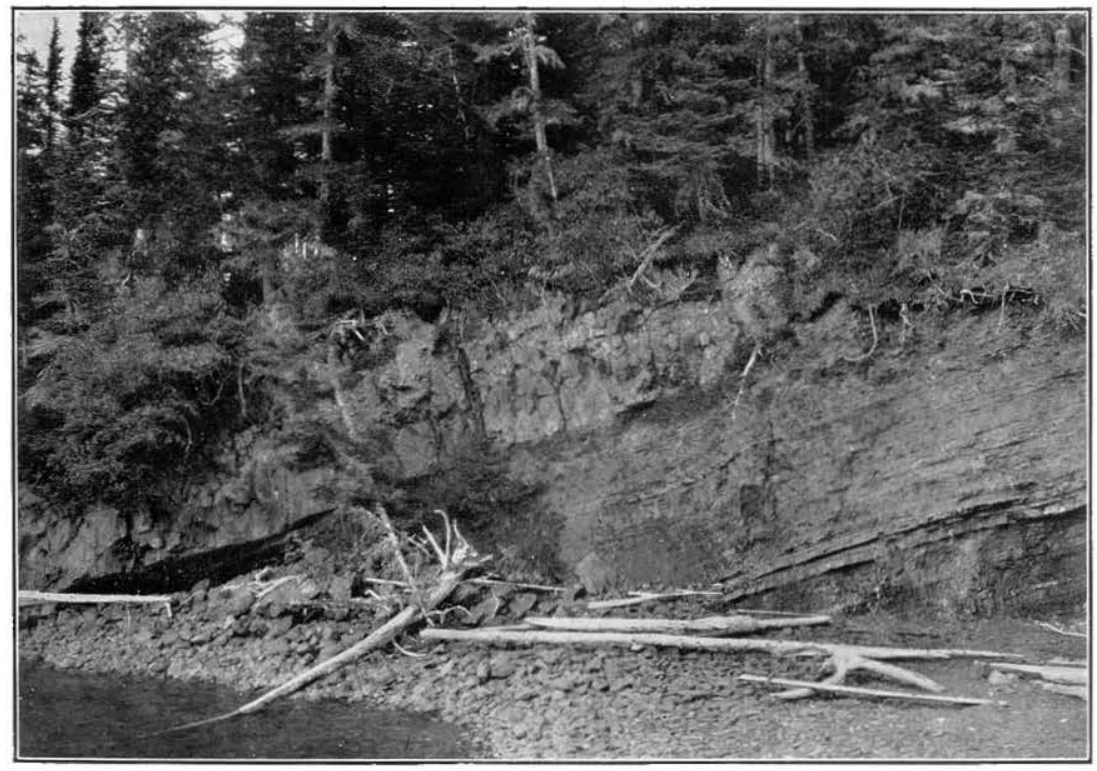

B. SLATE OF THE ORCA GROUP OVERLAin BY GREENSTONE NEAR ROCKY POINT.

Fragments of slate found here contained worm tubes (Terebellina palachei Ulrich). 

ORCA GROUP.

GENERAL DESCRIPTION.

The Orca group was named by Schrader ${ }^{a}$ in 1900, and was later studied by Schrader and Spencer. ${ }^{b}$ Lithologically the Orca group consists of graywackes, slates, and greenstones, with subordinate amounts of conglomerates and limestones. The rocks here termed graywackes vary from true graywackes to arkoses and to sandstones and quartzites, but the general similarity of these rocks and the angular nature of their constituent grains, which are embedded in a sparse cement or matrix, show that they are all closely allied and can be grouped for convenience of description under one name. The rapid alternation of bands of slate and graywacke is a characteristic feature of many outcrops of the Orca rocks. (See Pl. VII, A.) The slates, both black and gray, and graywackes are found very abundantly in exposurts of Orca rocks. Soft black slates are more common in the lower part of the formation and are in many places associated with the greenstones.

Conglomerates occur in a number of places, especially (1) on both sides of the entrance to Galena Bay, (2) on the north shore of Fidalgo Bay west of Fish Bay, (3) on the north shore of Orca Bay between Sheep and Simpson bays, (4) on the northwest side of Latouche Island near the Bonanza mine, (5) near the northeast corner of Hoodoo Island, and (6) on the northwest side of Elrington Island. The conglomerates will be described further in connection with the special descriptions of the Orca group.

Limestones are not common. They occur in small amount (1) north of the entrance to Galena Bay where the Orca rocks are near to the Valdez, (2) just north of Gravina Point, (3) on Cedar Bay on the north side of Hawkins Island, and (4) at the Banta shaft of the Reynolds-Alaska Development Company on Latouche Island. At the first-mentioned locality limestone, or, rather, calcite, occurs as a cement to some of the coarse-grained fragmental rocks at the base of the Orca group. At the second locality are a few low exposures of finely banded, highly contorted, fine-grained siliceous limestone, which is red, gray, and green in color. At the third locality the limestone " consists of layers varying from 1 to 2 feet or more in thickness. It is compact or dense in texture and dark blue or black in color." c At the fourth locality a number of blocks of coarse-grained gray lime-

a Schrader, F. C., A reconnaissance of a part of Prince William Sound and the Copper River district, Alaska, in 1898: Twentieth Ann. Rept. U. S. Geol. Survey, pt. T, 1900, pp. 404-408.

${ }^{b}$ Schrader, F. C., and Spencer, A. C., The geology and mineral resources of a portion of the Copper River district, Alaska, a special publication of the U. S. Geol. Survey, 1901, pp. 37-44.

- Schrader, F. C., op. cit., p. 406. 
stone were found on the dump from a shaft about 100 feet deep. This limestone probably came from a bed near the bottom of the shaft. The rock is porous and contains grains of quartz and flakes of musco. vite. Some black, calcareous bands have been found elsewhere in the slates and are probably more common than the field notes would indicate, for such bands are easily overlooked.

The greenstones are abundant in the lower part of the Orca, and their distribution is shown on the geologic map (Pl. II). They are in the main surface flows, interbedded with the sediments. One very marked characteristic of these greenstones is their ellipsoidal character. (See Pl. VIII.)

The Orca rocks can be separated into two divisions, one of which is characterized by the presence of much greenstone with subordinate amounts of slates, usually black in color, graywackes, and conglomerates. The other division has little or no greenstone, and consists of slates and graywackes. The division characterized by greenstone lies next to the Valdez rocks on the north and west sides of the sound, and is older than the division consisting of slates and graywackesthat is, the early part of the Orca was a period of extrusion of many flows of basic lava, with which were deposited varying amounts of sediments. The main volcanic activity seems to have taken place near the shore line of the Orca Sea, while farther out sediments were being deposited, and finally sedimentation became the prominent phenomenon even near the shore line. This explanation, together with the general synclinal structure of the Orca rocks, will account for the distribution of the two divisions of the Orca group about the sound. (See Pl. II.) It is probable that Hawkins, Hinchinbrook, and Montague islands all lie in the upper division of the Orca, but sufficient information is not at hand to warrant a positive statement on this point.

SPECIAL DESCRIPTIONS.

GALENA BAY.

On both sides of the entrance to Galena Bay there are extensive exposures of conglomerates, greenstones, and black slates, with smaller amounts of graywacke. The exposures on the north side of the entrance are of special interest because they lie near the junction of the Orca and Valdez groups. This junction line runs from the shallow bay which is about a mile north of the entrance to Galena Bay southeastward nearly to the mouth of the stream that enters Galena Bay about the center of its north side. To the north and east of this line, as exposed along the shore, are slates and graywackes, with no observed greenstones except some small dikes in one exposure. These slates and graywackes, belonging to the Valdez 


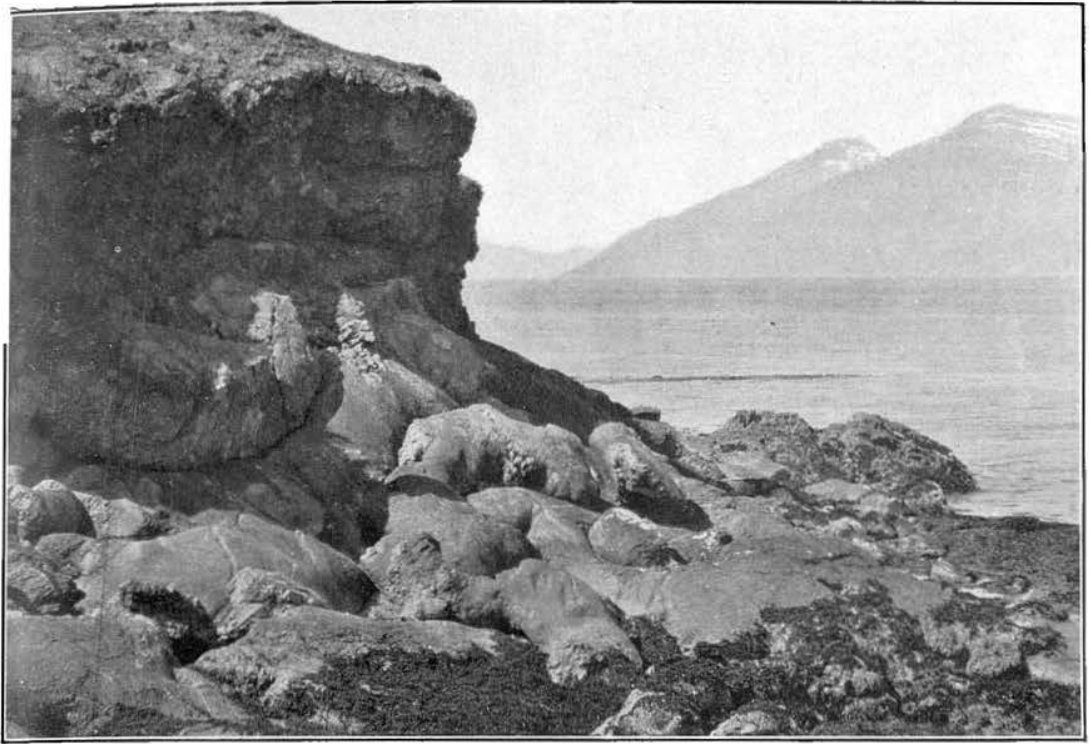

A. ELLIPSOIDAL GREENSTONE NEAR ROCKY POINT.

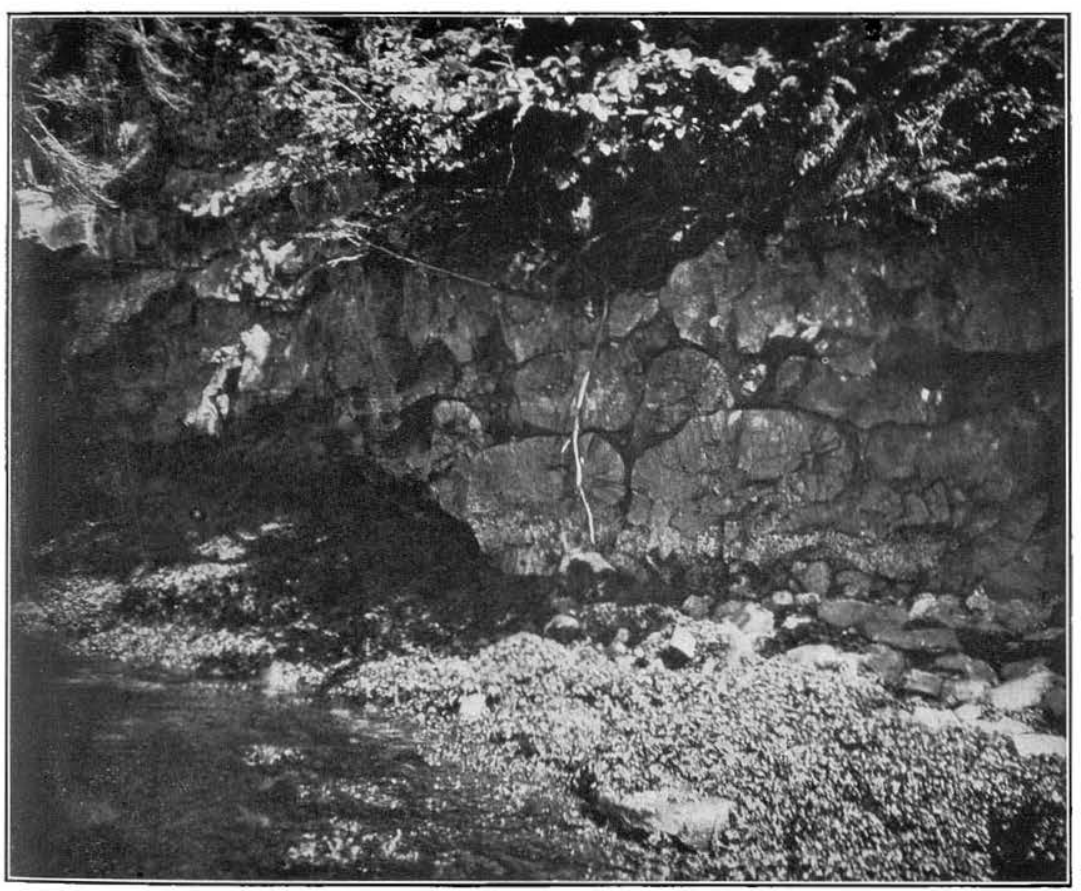

B. SECTIONS ACROSS ELLIPSOIDAL GREENSTONE NEAR ROCKY POINT. 

group, are considerably fractured and closely folded. North of the above-mentioned junction line the slates and graywackes strike westnorthwest, with dips of $35^{\circ}$ to $70^{\circ}$ NNE. The rocks lie in closely compressed folds, overturned to the south-southwest, and these folds pitch toward the west-northwest. On the north shore of Galena Bay, east of the junction line, the direction of strike is not constant and the dip varies from $55^{\circ}$ to $90^{\circ}$.

On the south and west of this junction line lie the rocks of the lower part of the Orca group. Instead of highly folded and fractured slates and graywackes there are gently folded (with dips of $10^{\circ}$ to $30^{\circ}$ ) greenstones, conglomerates, and slates, with smaller amounts of graywacke.

At the head of the shallow bay (above mentioned) about a mile north of the entrance to Galena Bay are extensive exposures of a rock which consists of fragments of all sizes, up to those a foot in diameter, embedded in a matrix that varies from a coarse graywacke,

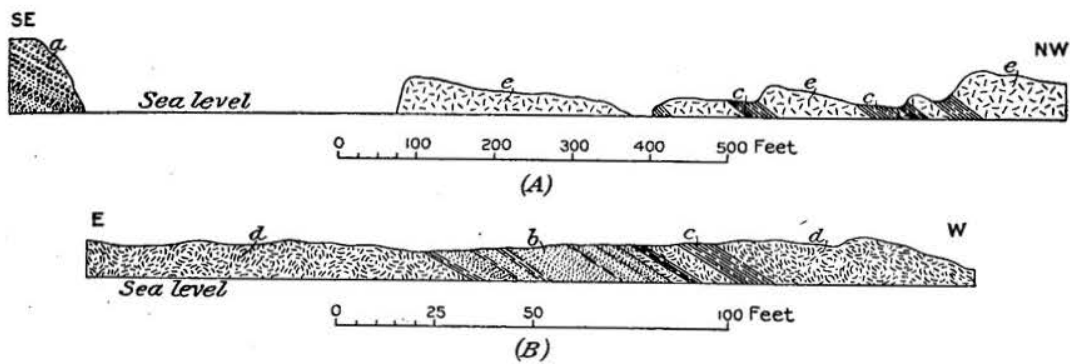

Figure 1.- Interbedding of sediments and basic lava flows, Orca group. A, About 1 mile north of the entrance to Galena Bay; $B$, south side of Galena Bay, directly south of $A$. $a$, Conglomerate and breccia ; $b$, graywacke; $c$, slate; $d$, ellipsoidal greenstone ; $e$, diabase.

with calcite cement, to a fine black slate. Bedding is not prominent, but there are some bands which are of fine grain and are continuous for a distance of 30 feet. These $\operatorname{dip} 10^{\circ} \mathrm{N}$. $32^{\circ}$ W. The fragments in this matrix consist, at the north end of the exposures, largely of slates and graywackes similar to those seen in place to the north. Toward the south end of the exposures the fragments are larger and consist mainly of fine-grained gray diabase, subporphyritic diabase, and basic amygdaloids. The fragments vary from angular to well rounded, though the angular and subangular ones are more common. The rock of these exposures is probably to be explained as fragmental volcanic material deposited in water along with rapidly accumulating coarse sediments. These exposures are evidently close to the base of the Orca.

On the south and southwest sides of the above-mentioned bay there is a distance of some 500 feet between the exposures just described and the next exposures, a series of interbedded diabase flows and 
black slates, six of the former and five of the latter. (See fig. 1, A.) The strike here is $\mathrm{N}$. $78^{\circ} \mathrm{E}$. and the $\operatorname{dip} 25^{\circ} \mathrm{N}$. To the west there are other bands of slate between lava flows, and a most impressive exhibition of flows of ellipsoidal greenstones. (See Pl. VIII.)

Near the end of the point southwest of this bay are other exposures of slate and greenstone, at one of which worm tubes (Terebellina palachei Ulrich) were found. (See Pl. VII, B.) Farther south, on both sides of Galena Bay, are other exposures of conglomerates, slates, greenstones, and graywackes intimately interbedded with each other. The relations of the sediments and the ellipsoidal greenstones at one of these places is shown in figure $1, B$.

ELLAMAR AND BLIGH ISLAND.

Along the shore line from Rocky Point to a place within a mile and a half of Ellamar are many exposures of greenstones, which are commonly ellipsoidal, and of black slates with graywackes. The passage between Ellamar and Bligh Island, known as Tatitlek Narrows, lies in an easily eroded mass of closely folded black slate. This rock appears in outcrops on both sides of the passage. The strike is in general northwest and southeast. The long, narrow island in Tatit lek Narrows is made up largely of a dike of coarse-grained diabase The northeastern lobe of Bligh Island is composed of greenstones anc slates, as is Busby Island. The main part of Bligh Island consist: of slates and graywackes. These rocks lie in more open folds than are common about Prince William Sound. The axes of the folds have a general northwest-southeast trend.

KNIGHT ISLAND.

The southeastern part of Knight Island, southeast of a line running from the entrance to Discovery Bay to the eastern arm of Mummy Bay, is composed of slate and graywacke, with little greenstone. The rest of the island is almost entirely of greenstone. This rock is ellipsoidal in many places, but toward the center of the island the ellipsoidal nature is not so evident and the country rock is largely altered diabase, which in places has become a greenstone schist. Near the head of the southeastern arm of Herring Bay, Knight Island, and also near the head of the eastern arm of this same bay greenstone occurs in three distinct phases as follows: (1) The common ellipsoidal flows; (2) fairly coarse grained green diabase whose augite has largely changed to hornblende; (3) fine-grained, dark, almost black, fresh diabase cutting the other rocks in small dikes. About a mile east of Mallard Bay, one of the southern arms of Drier Bay, the greenstone is schistose, hard, and siliceous and has an appearance of greater age than the usual types of greenstone. 
LATOUCHE ISLAND.

The geology and topography of parts of Latouche Island are shown on the special map ( $\mathrm{Pl}$. XII) and in figures 2 and 3. The long axis of the island trends northeast and southwest, and this is the general strike of the rocks of the island. These rocks are in the main graywackes and slates of the Orca group. Near the south end are some basic dikes, and near the northeast corner of the island a small amount of gabbro has been intruded into the sediments.

Conglomerate occurs especially on the point southwest of the dock of the Bonanza mine. The matrix of the conglomerate is a coarse-

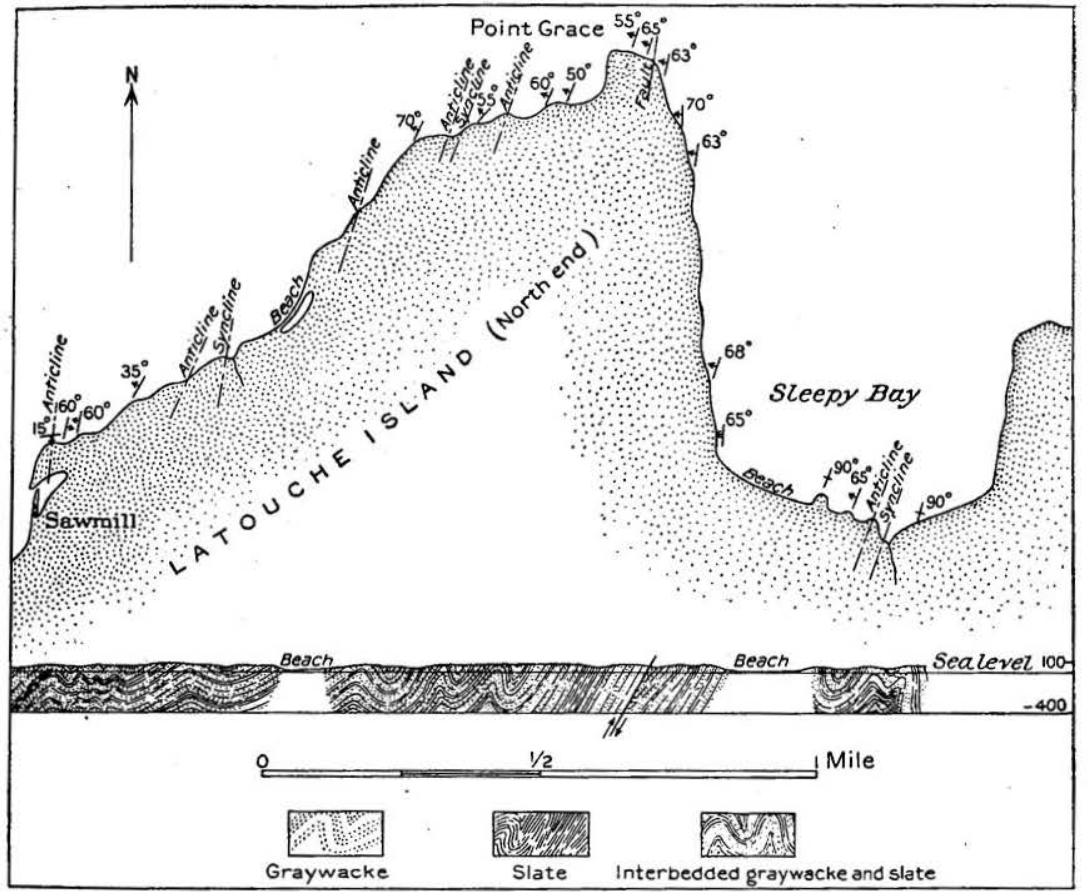

Figure 2.-Map and section of the northwest end of Latouche Island, showing the district just northeast of that shown on Plate XII. The horizontal and vertical scales of the section are the same.

grained graywacke, and the pebbles are well rounded and vary in size up to those a foot in diameter. Vein quartz and slate, black and gray in color and in places flinty, are the common pebbles. Other pebbles are fine-grained gray granites of at least four types; white and gray quartzites; hard silicified quartz porphyries and trachytes, and more basic, porphyritic rocks that are probably andesites. The slates of the island are usually black in color, and are well exposed about the shores of Wilson Bay. Slates are more common near the northwest shore of the island, and graywackes are abundant on the north- 


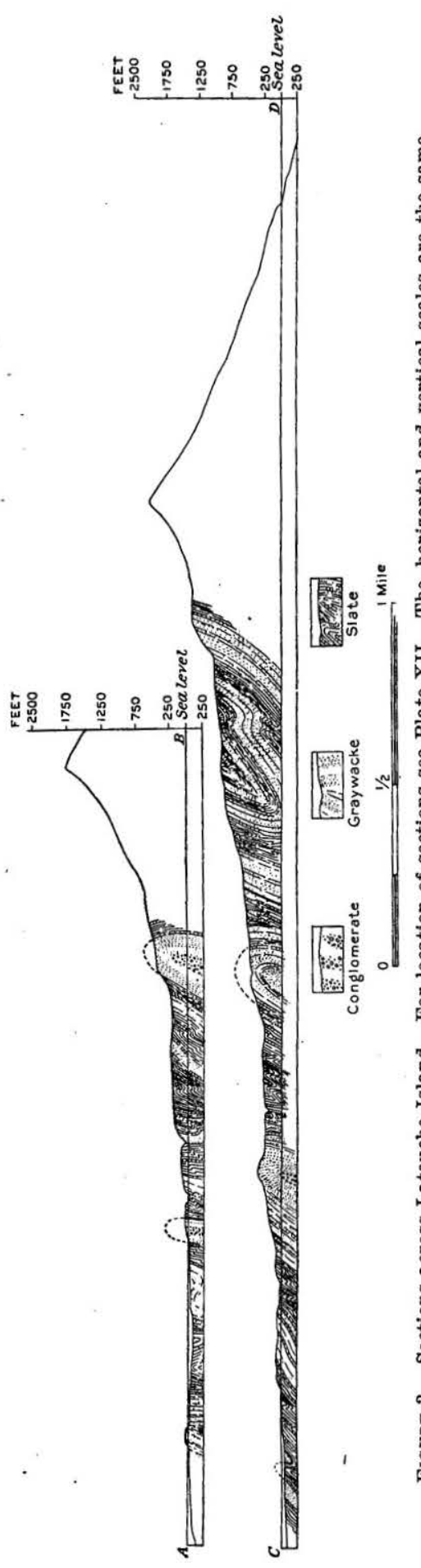

western slopes of the mountains. At the Bonanza mine the ore occurs chiefly in fractures in a hard, almost flinty aphanitic rock which is gray to greenish in color. The origin of this rock is not clear, but it is probably a highly siliceous sediment. At the Blackbird claim are some intensely sheared greenish rocks which may have originally been basic igneous rocks.

The rocks of Latouche Island have been subjected to close folding, the axes of the folds trending northeast and southwest. In some places, especially toward the center of the island, the folding has been more intense and some of the folds have been overturned slightly to the southeast. The axes of a number of the folds are shown on Plate XII. Superimposed on these folds are other gentle ones whose axes trend about at right angles to the axes of the main folds. On the northeast end of the island the main folds are more open and the cross folds are more distinct. (See fig. 2.) The conglomerate exposures described above are from the stratigraphically lowest rocks on the island and are regarded as marking a main anticlinal axis. This same belt of conglomerate occurs near the entrance to Wilson Bay, and probably also outcrops about a quarter of a mile southeast of Horseshoe Bay, where a number of loose blocks of the conglomerate were found. The general structure of the northwestern part of Latouche Island is shown by the sections in fig- 
ure 3. It is not improbable that dip faults complicate the structure, but owing to the monotonous lithology such faults are not easy of location.

HOODOO ISLAND.

The southwest end and the west and north sides of Hoodoo Island have many exposures of greenstone with some interbedded slate. At the northeast corner of this island is a small elongated island called Observation Island. Here and for half a mile to the west are excellent exposures of slate and graywacke with no greenstone. Just south of this small island is an anticline, 200 feet across, of conglomerate. The axis of the anticline pitches $10^{\circ} \mathrm{N} .7^{\circ} \mathrm{W}$. and the dips on either side of the axis run up to $45^{\circ}$. The conglomerate is clearly interbedded with the slate and graywacke. The pebbles are well rounded and vary in size up to those 8 inches in diameter. The pebbles are composed of quartz, quartzite, graywacke, flint, slate, quartz porphyry, and trachyte. This conglomerate and its pebbles resemble closely the conglomerate of the exposures on Latouche Island, and it is thought to belong near the base of the Orca group. To the south of Observation Island the conglomerate and interbedded slates and graywackes continue along the shore of Hoodoo Island for about 2 miles. These rocks occur in a series of folds, the anticlines of which are the more prominent. The axes of these folds average about horizontal and strike a little east of north. The west limbs of the anticlines have a dip of $30^{\circ}$ to $50^{\circ}$; the east limbs are steeper, in some places nearly vertical.

ELRINGTON ISLAND.

Near the southern part of Elrington Island, opposite a smaller island about three-quarters of a mile in diameter which is connected with the main island at low tide, are exposures of conglomerate, graywacke, slate, and greenstone. At the southeast are greenstones and black to gray slate, apparently interbedded. The strike of the slate is northeasterly and the dip $35^{\circ}$ to $55^{\circ} \mathrm{NW}$. The pebbles of the conglomerate are well rounded and consist of quartz, flint, quartz porphyry, fine-grained granite, quartz schist, and trachyte. No pebbles exactly like the greenstone and slate were noted. The conglomerate is interbedded with graywacke and exposures of these two rocks continue for half a mile to the northeast of this locality, the rocks growing finer in grain as the beds become higher. Whether the conglomerate here represents a newer formation resting unconformably on the slates and greenstones noted above is not clear.

$58668^{\circ}-$ Bull. $443-10-3$ 
AGE AND CORRELATION.

On Prince William Sound fossils have been found at several localities. The first were reported by Schrader, ${ }^{a}$ as follows :

No. 3. Northeast shore Hawkins Island. Two specimens. These specimens appear to represent portions of the cone of a Glyptostrobus or possibly a Sequoia. The form of the cone can not be made out, as the only portions remaining are a number of scales. If the appearance is not deceptive, these fragments are quite like certain Upper Cretaceous or Lower Tertiary forms, but are too indefinite to be of much value.

No. 20. Gravina Point, east shore of Prince William Sound. These are very small fragments covered with remains of fragments of plants, the nature of which can not be made out.

No. 24. Johnstone Point, north coast Hinchinbrook Island, Prince William Sound. The specimen is covered with a disconnected mass of fragments that have very little character. There is, however, one piece that has somewhat the appearance of a branch of a conifer. It has, or appears to have, three leaves attached to a branchlet and is not unlike Sequoia or Taxodium. It is too imperfect to be of any value in determining age.

Schrader and Spencer ${ }^{b}$ make the following statement:

Other plant remains were seen in Jackson Cove, on Glacier Island, during the fall of 1900 , but no recognizable specimens could be collected.

Other fragments of plants have been found on Simpson Bay, but these were too much altered to allow careful determination of their characters.

The Harriman Expedition reported the finding of a worm tube (Terebellina palachei Ulrich) in a bowlder from the moraine of the Columbia Glacier. ${ }^{c}$

Several similar worm tubes were found near the end of the point just north of the entrance to Galena Bay. This locality is shown in Plate VII, $B$. The fossils occurred in loose, angular rock fragments on the beach. These fragments are similar to the rock in place here, but none of the worm tubes were found actually in rock in place. There is, however, no reasonable doubt as to their belonging here.

In a coarse-grained gray limestone, found on the dump of the Banta shaft of the Reynolds-Alaska Development Company, east of Horseshoe Bay of Latouche Island, are a number of indistinct forms which may be the remains of organisms. The rock undoubtedly came from this shaft and probably from a depth of about

\footnotetext{
a Schrader, F. C., A reconnaisance of part of Prince William Sound and the Copper River district, Alaska, in 1898 : Twentieth Ann. Rept. U. S. Geol. Survey, pt. 7, 1900, p. 406.

b Schrader, F. C., and Spencer, A. C., The geology and mineral resources of a portion of the Copper River district, Alaska, a special publication of the U. S. Geol. Survey, 1901 , p. 39.

' Harriman Alaska Expedition, vol. 4, 1904, p. 134.
} 
100 feet below the surface. These specimens were submitted to E. M. Kindle. who reports as follows concerning them:

The rock is so greatly altered that it would be hazardous to assert positively that the supposed fossils in it are corals. However, the numerous cavities in the specimens rather strongly suggest that they represent the impressions of partly obliterated corals of the Favosites type. The very thin, closely spaced plates in the tube-like cavities appear to represent the septa in some species of Favosites. Corals of this general type are common in the Devonian and Silurian and are not entirely unknown in the Ordovician. If, therefore, the supposition that the impressions are corals be correct, it is not practicable to draw from them any more precise conclusion than that the horizon represented belongs to the Paleozoic.

At Controller Bay, about 80 miles southeast of Prince William Sound, and also at Yakutat Bay, some 160 miles farther southeast, a series of rocks occur which are similar in general characters to the sediments of the Orca group on Prince William Sound. A similar graywacke and slate.formation extends southwestward from Prince William Sound along Kenai Peninsula and occurs again on Afognak and Kodiak islands. All these rocks appear to be pre-Tertiary in age, and they have been grouped together as the Yakutat "series." $a$ This grouping is based on the general character of these rocks, on their relation to other terranes, on their approximate continuity, and especially on the occurrence in them at Yakutat Bay, at Prince William Sound, and at Kodiak Island of similar worm tubes (Terebellina palachei Ulrich). Moreover, at Kodiak Island a number of other fossils have been found, and Ulrich, after studying them, concludes that the age of the slates there is most probably Lower Jurassic. $^{b}$ Although the correlation of rocks over so extensive a district by the presence of one fossil, and that a worm tube, can not have many of the elements of certainty, still in the present state of knowledge concerning the stratigraphy of the coast of the Gulf of Alaska it is reasonable to regard the Orca group as of Mesozoic and in part probably of Jurassic age. It should be borne in mind, however, that on the southeastern part of Kenai Peninsula there are most probably two discordant formations of very similar lithology, and that present information does not permit a positive statement as to which, if either, of these is the equivalent of the Orca group or of the fossiliferous slates on Kodiak Island.

\section{IGNEOUS ROCKS.}

GRANITES.

The granites of Prince William Sound are in all places where they have been observed bosses intrusive into much contorted graywackes and slates. They were in but one locality noted near any of the green-

a Harriman Alaska Expedition, vol. 4, 1904, pp. 7, 47, 55, 125.

b Ulrich, E. O., Harriman Alaska Expedition, vol. 4, 1904, p. 132. 
stones of the district. Consultation of the map (Pl. II) shows an irregular line of these intrusions extending around the sound, where they usually form bold topographic features.

GRANITE OF EWAN BAY.

The backbone of the tongue of land. separating Ewan and Paddy bays is occupied by a granite mass which is probably not connected areally with the Eshamy granite, as there is a strip of low country joining the heads of Paddy and Whale bays. The granite is light gray in color and is moderately porphyritic, with a rather finegrained groundmass. The larger crystals are orthoclase, and the minerals of the groundmass are quartz, orthoclase, plagioclase, bio. tite, and very small amounts of hornblende, magnetite, apatite, and zircon. The plagioclase is normal oligoclase in composition.

The granite was nowhere seen in actual contact with the surrounding graywacke, but numerous bowlders of recrystallized graywacke pierced by aplite dikes give ample evidence of the intrusive character of the granite. The baked graywacke is of a grayish-brown color very characteristic of the baked graywackes of the sound. This color is the modification of the gray of the unaltered graywacke which is produced by the dark-brown mica, biotite, developed in the sediment by the metamorphic action of the intrusive granite. Near the granite the : ock is so changed that its sedimentary character is evident only by tracing it away from the granite till it grades into a rock which is certainly a sediment. Although completely crystallized, its clastic character is easily seen by means of the microscope. The brown color is caused by the multitude of tiny biotite flakes scattered diversely through the rock. Bands of quartz grains coarser than the adjacent grains indicate the original bedding. The quartz grains, together with the much scarcer grains of orthoclase and plagioclase, are closely fitted to each other with interlocking margins. The original more rounded grains with very finely divided interstitial clayey material have been worked over during metamorphism to this form. Black grains of magnetite are sparsely scattered through the section.

ESHAMY GRANITE.

The granite mass practically surrounding Granite Bay and oceupying nearly all of the neck of land between Granite and Eshamy bays has been termed the Eshamy granite. Its contact with the sediments can easily be traced from a distance by the smooth spalled surface of the granite and the darker color of the sediments. Where perfectly fresh the granite is of a pinkish-gray color, but the outer foot with surface exposed to the weather is pink, and the outermost 2 or 3 inches is stained brown by limonite. In places it is somewhat gneissic, but the typical phase of the main granite is of a medium- 
grained granitoid texture. The darker minerals are roughly grouped in irregular patches 5 to 10 millimeters in diameter. These patches give the granite a slightly mottled appearance.

The microscope shows that a few of the orthoclase crystals are slightly porphyritic. These larger crystals are usually made up of zones of slightly different optical properties. The zones are presumably due to slight differences in the chemical and physical conditions of the molten rock while the orthoclase was crystallizing. Some of the crystals have been broken and the cracks healed by secondary quartz.

The quartz is very irregular and full of inclusions. In some places the boundaries between adjacent quartz grains are an intricate fretwork (Pl. IX, $A$ ), showing that the grains interlock in an exceedingly complicated way. This is probably due to a partial breaking up and partial cementing of the quartz during the deformation of the rock as a whole. The undulatory extinction and anomalous biaxial character of some of the quartz show that it has been subjected to great deformative forces.

Plagioclase, biotite, and hornblende are very prominent in the thin section and give a basic aspect to the granite. The plagioclase is andesine-oligoclase. It is closely twinned and in places is intergrown with individuals of the same species. The biotite is considerably more abundant than the hornblende. The accessory minerals are magnetite, apatite, zircon, and sphene. These minerals have a tendency to cluster about or to be included in the biotite and hornblende.

Locally there are more basic phases of the Eshamy granite. At the south side of the entrance to Granite Bay the two phases, acidic and basic, seem to have been mixed while still in a plastic or semiplastic condition. The field relations show that the more acidic phase was intruded soon after the more basic phase.

The contact between the granite and the graywackes is very sharp. At the side of one dike several feet wide the granite becomes a little more acidic within a few centimeters of the contact. The actual transition takes place in a few millimeters, but the microscope shows the graywacke substance trailing out into the granite for several millimeters. The biotite of the recrystallized graywacke is slightly concentrated in the first few millimeters of the graywacke, but in the next few millimeters it is slightly depleted. Numerous aplite dikes cut the graywacke and the granite in all its phases for many feet on each side of the contact.

Near this locality the granite cuts a greenstone. This greenstone is a diorite, probably derived from a diabase, and it is the only basic igneous rock noted on the west shore of the sound. 


\section{PLATE IX.}

\section{Photomicrographs.}

A. Partly granulated quartz with fretted margins, from Eshamy granite; specimen G $269 . \times 16$, crossed nicols.

$B$. Poikilitic quartz with core free of xenocrysts, from Esther granite; specimen G 301. The black line incloses the quartz of the same orientation. $\times 16$, crossed nicols.

C. Reaction rim of actinolite between olivine and labradorite, from gabbro on Esther Island; specimen G $293 . \times 16$, crossed nicols.

D. Amphibole cross sections from dike near Barry Glacier; specimen G 430 . These areas are now made up of chlorite, epidote, and calcite, but their shape indicates that these minerals have resulted from the alteration of an amphibole, probably hornblende. $\times 54$, ordinary light.

E. Quartz phenocryst fractured, with slight displacement, from quartz porphyry of Unakwik Bay; specimen G 305 . The secondary quartz healing the break is irregular in its orientation, except between the parts of the phenocryst, where it was deposited with the same orientation as the phenocryst. $\times 16$, crossed nicols.

$F$. Sliced orthoclase crystal from a squeezed aplite dike on Esther Island; specimen G 300. The line AA is the longer axis of the crystal, and there are four cross breaks roughly parallel to the cleavage. $\times 54$, crossed nicols. 

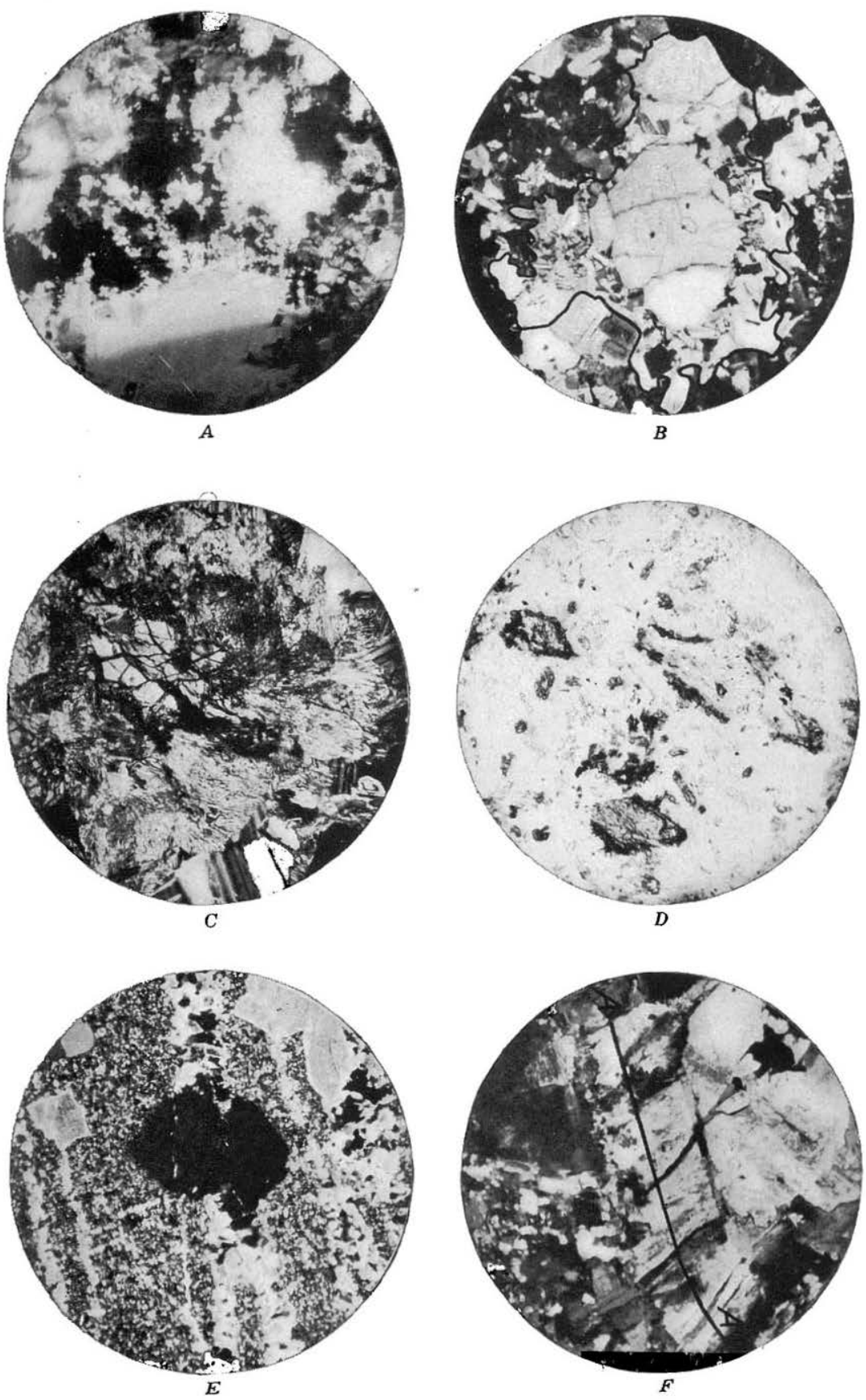

PHOTOMICROGRAPHS. 



\section{NELLIE JUAN GRANITE.}

The Nellie Juan granite occurs in the western part of the sound, on the south shore of Port Nellie Juan. It extends along the shore for a distance of about 5 miles and inland for an unknown distance. It is surrounded by the graywackes and slates of the Valdez group, but no examination of the immediate contact was made. The rock is of two distinct types which grade into one another. They are the main body of the granite and a distinctly porphyritic phase. The main granite is very light pink in color; the porphyritic phase is of a light-gray cast.

The rock is a typical biotite granite with a small portion of plagioclase which is a little more acidic than oligoclase. The phenocrysts (orthoclase), as well as the smaller feldspar crystals, are as a rule markedly zonal in structure. The quartz has a tendency to segregate into areas seemingly of one large grain but in reality of several small grains.

The ferromagnesian minerals are biotite, of the variety anomite, and a less amount of hornblende. The biotite is altering to chlorite, becoming greenish as alteration approaches, but maintaining its strong birefringence. The hornblende is commonly twinned parallel to $(100)$, rarely repeated once or twice.

Magnetite, apatite, zircon, and sphene are present as accessory minerals. The magnetite is almost invariably included as rounded grains in the biotite. There occur in addition to these minerals a few tiny grains of a wàrm brown pleochroic mineral which is probably allanite.

\section{GRANITE OF CULROSS ISLAND.}

A small area located about the middle of the western part of Culross Island - that is, on the east side of Culross Passage - consists of granite associated with a basic granitoid rock which might on casual observation be mistaken for a phase of the granite. This rock is a somewhat altered gabbro rather high in plagioclase feldspar (labradorite) and with a partial ophitic texture. It may be a differentiation phase of the granite, which itself is of a distinctly basic type, but the general relations point to its being a separate intrusion not related immediately, at least, to the granite.

The granite proper has been intruded into slates and graywackes. Beautiful contact features with graywackes may be seen on the beach at the northern limit of the granite. The granite is rather dark gray in color, owing to the liberal portion of biotite present. The color changes to pink and light brown as weathering progresses.

The quartz is very irregular in outline. It shows marked undulatory extinction and contains numerous sheets and lines of inclusions which are roughly parallel throughout the section. The orthoclase 
and soda-lime feldspar are both somewhat altered to sericite. The plagioclase is not constant in composition, but there is a variation from nearly pure albite in some individuals to oligoclase-albite in others. The average composition of the plagioclase is about $\mathrm{Ab}_{85} \mathrm{An}_{15}$.

The biotite is the variety anomite and is altering to actinolite. Magnetite, apatite, zircon, and sphene are not uncommon. Rare small brown grains, probably allanite, occur associated with the biotite.

Aplitic phases of the granite are finer grained and lighter in color than the main granite. The latter fact is due to the decrease in the quantity of the biotite. The most notable feature of this aplite is the white acidic band or zone at the immediate contact with the graywackes. At a distance of about 1 centimeter from the contact the quartz begins to increase and the biotite to decrease. Orthoclase also replaces the plagioclase in part. At 2 to 3 millimeters from the contact the biotite abruptly disappears except for an occasional isolated individual, and the quartz becomes strongly predominant. The actual transition to the graywacke takes place in 0.2 to 0.3 millimeter. For a distance of 15 millimeters from the contact there is no apparent change in the degree of anamorphism in the graywacke. However, the baking is less at several feet from the contact, but the further gradation into unaltered graywacke was not observed.

The metamorphosed graywacke presents even to the unaided eye decisive evidences of anamorphism in its well-marked crystallinity and in the presence of biotite, presumably developed from the original clayey constituents. The general color is a little lighter gray than the ordinary graywacke observed in the district. Countless spangles of biotite appear on the fractured surface.

\section{GRANITE OF PASSAGE CANAI.}

On the north side of Passage Canal is a mass of gray granite roughly elliptical in outline about 4 miles long and 2 miles wide. From a point 4 miles west of Point Pigot it is exposed for 2 miles westward along the shore. The northern part of the mass is hidden under a glacier. Near the contact on the east the granite is much fractured, as are also the adjoining graywacke and slate, though to a less degree than the granite. The granite sends a very few stringers of aplite into the surrounding rock. The sediments are schistose at the contact, becoming hardened at 100 feet, and further grading into unaltered graywacke and slate. Numerous inclusions of mica schist, probably altered fragments of the sediments, are present in the shore exposures. Hence it is probable that the contact is in the bay not far from the shore. 
The granite is decimillimeter-grained, though a few individual quartz grains attain 2 millimeters. The feldspar is, in the main, orthoclase, altering to kaolin and muscovite, but a few crystals of plagioclase varying between andesine and oligoclase are present. The only dark mineral in the granite is biotite, in part altered to chlorite. Minor amounts of apatite, magnetite, and zircon are present.

To the east of this granite, near Point Pigot, are several finegrained, very light-colored dikes, weathering to a deep brown. Under the microscope the brown material is seen to be limonite derived from siderite. The major portion of the rock is oligoclase and siderite, with quartz in less amount. Little or no orthoclase is present. Considerable secondary white mica occurs in the rock. The siderite is probably secondary also, but no decisive evidences of its secondary origin are to be seen. It is in fairly definite patches and might possibly be original.

\section{ESTHER GRANITE.}

The Esther granite mass occupies the greater part of Esther Island, at the south end of Port Wells. It is one of the two largest granite masses about the sound. It presents the huge spalled-off surfaces so characteristic of the granites in this district, and these distinctive hills may be easily recognized at a distance of several miles. All the phases of this granite are more or less gneissic. Especially is this true of the granite on the northern and eastern parts of Esther Island, where the gneissic structure is very pronounced.

The granite is in most places slightly porphyritic, with orthoclase phenocrysts. The quartz is very undulatory and segmental in its extinction, and much of it is distinctly biaxial. The quartz of the granite on the east side of the island is partly granulated. The margins between the grains are of the intricate character shown in Plate IX, $A$, though the illustration represents another granite. In- one place the quartz is partly poikilitic, inclosing small crystals of orthoclase. Plate IX, $B$, shows such a quartz grain with a solid core. The solid central part prebably formed before the small crystals of orthoclase, so that they were included in only the outer part of the quartz individual. The segregative quality of both the quartz and the ferromagnesian minerals is very marked in this granite. The quartz groups can be distinguished by close inspection of the hand specimen, and the groups of dark minerals give the granite a mottled appearance in some localities.

Potash and lime-soda feldspars are present. The first occurs in crystals of two orders of magnitude, one slightly porphyritic, the other of the same general size as the groundmass. The larger ones and many of the smaller ones are markedly zonal in structure. The lime-soda feldspars rarely attain the size of the phenocrysts of ortho- 
clase. Their composition is about $\mathbf{A b}_{65} \mathbf{A n}_{35}$, or oligoclase-andesine. Many of the crystals have more acidic rims grading to about albiteoligoclase in composition.

The dark minerals are biotite and hornblende. All phases of the Esther granite have a considerable amount of biotite, but the amount of hornblende varies from scarcely any to as much as the biotite. The platy crystals of biotite are arranged roughly parallel to the planes of the gneissic structure of the rock. In fact, it is this arrangement of the black mica plates which is very largely the cause of the gneissic structure. The plates are so bent and twisted and the edges of the plates are so ragged that the mica seems to have been intensely squeezed by the neighboring crystals. In other places the edges of one biotite flake feather out against another, showing that there has been slipping or gliding between the laminæ of the mica. The hornblende is so granulated that nearly all traces of its original form are gone.

The accessory minerals are magnetite, apatite, zircon, and a very small amount of sphene.

Many aplitic dikes extend from the granite into the surrounding sediments. One dike located in a little bay on the south side of the island contains a few small red garnets. The garnets are probably original, though the dike has been subjected to intense shearing forces. Microfaults are numerous and twinned feldspars with bent laminæ are common. Here and there the feldspars are sliced into several fragments by breaks along the cleavage planes (PI. IX, $F$ ).

On the east side of Esther Island the granite cuts a gabbro. On the northeast side of Esther Passage there is a quartz diorite which may be related to the granite.

The sediments surrounding the Esther granite are much sheared and metamorphosed. On the north shore of Esther Passage are metamorphic sediments, including baked graywacke, mica schist, and knotenschiefer. The baked graywacke is brown in color and composed of a mixture of quartz and biotite grains with a few orthoclase and plagioclase grains. The rock has been under shearing stresses, as shown by the curved bands of minute biotite flakes. The biotite seems to be in the process of formation from the fine-grained matrix between the larger quartz and feldspar grains. A specimen of schist obtained near the graywacke gives evidence of great dynamic metamorphism and shows intricate but obscure folding. It is dark gray in color, speckled with tiny black-mica plates which are arranged in bands. Besides these dark bands there are light-colored and quartzite-like bands. Examination with the microscope shows the mica in wavy bands wrapping about lighter-colored and harder minerals. There are large grains of a colorless mineral in these biotite bands, which are the same as the lightest-colored material in the 
hand specimen. This mineral is sillimanite, probably produced by the dehydration of the kaolin of the original sediment. The quartz bands have a distinctly fragmental aspect, but there has been a large amount of granulation of the original particles. A light-green, faintly pleochroic mineral with very weak double refraction is present in small amount. It is seemingly an alteration product of the mica and is probably one of the serpentines.

The granite near the graywacke contact is but very little finer grained than the usual phase, but the sediments have increased very greatly in coarseness of grain near the contact. The clastic character of the sediments is still made evident, however, by the shapes and arrangements of the quartz grains, which occupy about one-half of the thin section. Plagioclase and orthoclase grains occur sparsely in about the same ratio as in the fresh graywackes of the district. The increased size of the biotite and its development of parallelism to the cleavage direction, the close interlocking of grains, and the absence of finer-grained matrix are the characteristics of this rock as compared with the less anamorphosed rocks of approximately the same original character.

The knotenschiefer is characterized by the small ellipsoids, flattened in the plane of cleavage, from which it was named. These granules are from 1 to 3 millimeters in greatest dimension. They istand out on the weathered surface. The rock is very slaty in its general aspect, but many siliceous bands are present. Under the microscope the rock is seen to be composed of fine-grained quartz, locally in veins, small black irregular patches of magnetite, multitudes of tiny plates of biotite, and, smallest of all, clouds of extremely minute black specks, possibly carbonaceous matter. There is one other mineral which is probably sillimanite, but the small size of the individuals precludes accurate determination of the species. The rods of this mineral lie in general parallel to the mica plates-that is, parallel to the rock cleavage. In the knots the rods and quartz grains are more abundant, but the arrangement of the rods is more diverse. The cause of the knots may be the more active change in these places from original kaolin to sillimanite and quartz."

\section{CEDAR BAY GRANITE.}

Cedar Bay is the main eastern arm of Wells Bay, in the northcentral part of the sound. The Cedar Bay granite surrounds twothirds of this bay and forms the core of the neck of land between Wells Bay and the passage northwest of Glacier Island. The granite extends well up into the head of the northeast arm of Wells Bay. At this place the granite of the main mass-that is, several hundred

\footnotetext{
a Van Hise, C. R., A treatise on metamorphism: Mon. U. S. Geol. Survey, vol. 47, 1904, pp. 316-317.
} 
feet from the contact with the surrounding graywacke-is of a lightgray color. The size of grain is 0.5 to 2 millimeters. A few of the feldspars are about one order larger in size than the average grain of the body of the rock. The granite is of a very even grain and the quartz is in more regular shapes than that of the other granites of the sound. The stress phenomena in the rock are very slight. There are no fractures, no granulated quartz, no bent biotite flakes, and very little undulatory extinction of the quartz.

The orthoclase is very irregular in outline and contains many tiny flakes of white mica. The plagioclase is andesine-oligoclase, $\mathrm{Ab}_{65} \mathrm{An}_{35}$ in composition. It is not a very prominent constituent of the rock. The biotite is greenish brown in color and is very largely altered to chlorite. Small amounts of hornblende, magnetite, apatite, and zircon occur as accessory minerals. In some localities the granite has more of the darker minerals than in others, but on the whole it is rather acidic.

At the head of the small bay just south of Cedar Bay the granite occurs in two phases. Microscopic examination, however, shows but one of these to be of granitoid texture. This phase is very much like the granite at the head of the northeast arm of Wells Bay in both its texture and its mineralogical constitution. The other rock is very white in color, being in many places as white as marble. The microscope reveals it to be a porphyry with microgranitic groundmass. The phenocrysts occupy about as much of the rock as the groundmass. They are quartz and orthoclase, and a small number are oligoclase. The groundmass is composed of the same minerals. The remarkably light color of the porphyry is caused by the chalky aspect of the feldspars, due to rather advanced alteration, and by the almost complete lack of dark-colored minerals.

The granite at 10 feet from the contact with the sediments in the northeast arm of Wells Bay has a subporphyritic texture with orthoclase phenocrysts. The average size of grain is somewhat less than that of the main granite. There is seemingly no difference in the basicity of the granite. At 10 inches from the contact the granite is a porphyry with decimillimeter-grained groundmass and millimeter-grained phenocrysts of quartz and orthoclase. Numerous small areas of the groundmass and parts of some of the orthoclase phenocrysts are micropegmatitic. About many of the phenocrysts the grain of the groundmass is a little finer than the average. Very little plagioclase is present. Biotite occurs in subordinate amount. Immediately at the contact the grain becomes somewhat coarser and the phenocrysts more abundant. The last few millimeters are composed only of quartz and orthoclase. A white band marking this contact zone may be seen very distinctly. 
The contacts of the larger dikes with the sediments are the same as those of the granite, but as the dikes become smaller (several millimeters wide) they become finer grained and contain only quartz and orthoclase, with a rare crystal of plagioclase. In a few places a slight mixing of the baked graywacke particles and the aplite can be observed. As the dikes become still finer they become more and more quartzose. When the dikes are a few tenths of a millimeter in width, only an occasional orthoclase crystal is present. Those which occur are in general larger than their quartz neighbors and are almost invariably in simple Carlsbad twins. The very finest ends of the dikes are made up of nothing but quartz.

SHEEP BAY GRANITE.

A granite mass occupies the northeast third of the point of land separating Port Gravina from Sheep Bay. It is light gray in color and is the coarsest-grained granite of the sound. It is millimeter grained, composed of about one-half quartz, one-third orthoclase, and the remainder plagioclase, biotite, and accessory minerals. The granite is in contact with fine-grained baked graywacke at the head of Port Gravina.

The quartz varies from a few tenths of a millimeter to nearly 10 millimeters in width, averaging about 2.5 millimeters. It has strong undulatory and segmental extinction. In many places the quartz has been fractured and the cracks are filled with fine-grained secondary quartz. Lines and sheets of inclusions are extremely abundant. They traverse from grain to grain of the quartz without break. There seem to be two systems of these inclusion sheets, whose directions are in part certainly related to the fracture directions. Many of the segments of the segmental extinction are bounded by inclusion sheets. It is therefore clear that these inclusions are secondary and have been induced by deformative forces acting upon the quartz.

The orthoclase is very irregular in shape, and as a rule simply twinned according to the Carlsbad law, though the twins are locally repeated two or three times. It is quite fresh, except near the ironbearing minerals, where the alteration to sericite is well begun. The larger orthoclase crystals are intergrown with thin, nearly flat plates of another feldspar, probably albite.

The plagioclase is distinctly zonal in its usual occurrence. The bodies of the crystals are oligoclase-andesine and the rims are as acidic as sodic oligoclase.

The biotite occurs very commonly in hexagonal plates, by means of which the optical orientation is found to be that of the variety anomite. Alteration to chlorite has begun. Hornblende is absent, 
but very small amounts of magnetite, apatite, and zircon occur. Sphene is present in notable quantity in connection with altering biotite. This fact suggests that the mica is probably high in titanium.

At the head of Sheep Bay the granite has a larger proportion of ferromagnesian minerals. The rock has been much mashed in the zone of fracture. Some of the mica plates have been intensely sheared, and many of the brittle minerals have been partly granulated.

\section{OTHER GRANITE AREAS.}

In addition to the granites described above, a few small occurrences are known. The first of these is the granite on the west side of Port Bainbridge, near the head (see Pl. II), at a distance of $1 \frac{1}{2}$ to 2 miles from the shore. It forms the top of the first ridge west of the port. It was not visited, nor were specimens procured from the glacial streams coming down from the glacier which covers a third of the granite area. The granite is much lighter in color than the surrounding mountains of graywackes and slates. Its smooth, spalledoff sides and rounded top, features very characteristic of the granitic hills of the district, and its distinct contact with the darker rocks serve to distinguish it with little doubt as an intrusion of acidic igneous rock. The small granite mass peeping from under the glacier $1 \frac{1}{2}$ miles northeast of the granite just described may be part of the same body, as both disappear under but on opposite sides of the same ice field.

On the west side of Glacier Bay is a small boss of fine-grained granite porphyry composed of quartz and orthoclase, with a small amount of brown mica and green hornblende. Plagioclase is very sparsely scattered through the rock, A peculiar feature of this granite is the presence of slightly lighter colored, oval areas several centimeters wide, in which occur radial aggregates of a dark-green or black mineral. The phenocrysts in these places are slightly larger and more abundant than in the body of the rock. This dark mineral is probably an occurrence of tourmaline somewhat similar to that in the granite of Stone Mountain, De Kalb County, Ga., described by Watson. ${ }^{a}$ The biotite is more abundant in these places and is of a distinctly green color.

SUMMARY.

The subjoined tables show the mineralogical and chemical characters of four of the granites as determined by estimation of the relative quantities of each mineral in two to four selected thin sections by the Rosiwal method. ${ }^{b}$ The computation of the norm and the quantitative classification are according to Cross, Iddings, Pirsson, and Washing-

${ }^{a}$ Watson, T. L., The granitic rocks of Georgia and their relationships: Am. Geologist, vol. 27, 1901, pp. 206-207.

${ }^{b}$ Rosiwal, Verh. Wien. Geol. Reichs-Anst., vol. 23, 1898, p. 143. 
ton. ${ }^{a}$ Although these results are but approximations of the true compositions of the granites, they give a fairly definite idea of their characters. The composition of the biotite and hornblende of the Esther granite was assumed to be the same as that of like minerals in a similar rock from Butte, Mont. The composition of the biotite and hornblende of the Nellie Juan, Cedar Bay, and Sheep Bay granites was assumed to be the same as that of like minerals from somewhat similar rocks from the Yosemite Valley, California.

Average chemical compositions of the Nellie Juan, Esther, Cedar Bay, and sheep Bay granites.

\begin{tabular}{|c|c|c|c|c|}
\hline$\because$ & $\begin{array}{c}\text { Nellie Juan } \\
\text { granite. }\end{array}$ & $\begin{array}{c}\text { Esther } \\
\text { granite. }\end{array}$ & $\begin{array}{c}\text { Cedar Bay } \\
\text { granite. }\end{array}$ & $\begin{array}{c}\text { Sheep Bay } \\
\text { granite. }\end{array}$ \\
\hline 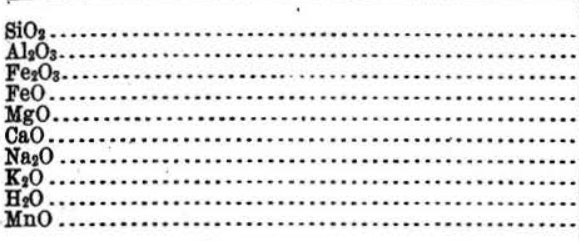 & $\begin{array}{c}72.7 \\
13.8 \\
.67 \\
1.43 \\
.9 \\
1.6 \\
1.3 \\
7.4 \\
.2 \\
.1\end{array}$ & $\begin{array}{r}66.7 \\
13.6 \\
1.4 \\
3.0 \\
2.9 \\
3.6 \\
1.6 \\
4.9 \\
.8 \\
.1\end{array}$ & 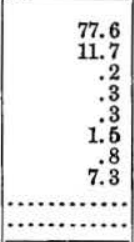 & $\begin{array}{r}79.4 \\
10.1 \\
.45 \\
1.07 \\
.8 \\
1.6 \\
.7 \\
5.4 \\
.1 \\
\ldots . .\end{array}$ \\
\hline & 100.00 & 98.6 & 99.7 & 99.62 \\
\hline
\end{tabular}

Average mineral compositions (modes) and norms of the Nellie Juan, Esther, Cedar Bay, and sheep Bay granites.

\begin{tabular}{|c|c|c|c|c|c|c|c|c|}
\hline \multirow{2}{*}{. } & \multicolumn{2}{|c|}{$\begin{array}{l}\text { Nellie Juan } \\
(\mathrm{I}, 4,2,2) .\end{array}$} & \multicolumn{2}{|c|}{ Esther (II, 4, 3, 2). } & \multicolumn{2}{|c|}{$\begin{array}{l}\text { Cedar Bay } \\
(I, 3,2,1)\end{array}$} & \multicolumn{2}{|c|}{$\begin{array}{l}\text { Sheep Bay } \\
(I, 3,2,2) .\end{array}$} \\
\hline & Mode. & Norm. & Mode. & Norm. & Mode. & Norm. & Mode. & Norm. \\
\hline 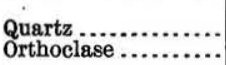 & $\begin{array}{l}33.1 \\
39.0\end{array}$ & $\begin{array}{l}29.5 \\
44.5\end{array}$ & $\begin{array}{l}30.7 \\
19.2\end{array}$ & $\begin{array}{l}27.6 \\
27.8\end{array}$ & $\begin{array}{l}-42.4 \\
41.5\end{array}$ & $\begin{array}{l}40.6 \\
44.5\end{array}$ & $\begin{array}{l}50.4 \\
29.7\end{array}$ & $\begin{array}{l}48.6 \\
33.4\end{array}$ \\
\hline Plagioclase ......... & $\left\{\mathrm{Ab}_{75} \mathrm{An}_{25}\right.$ & $\cdots \cdots$ & $\mathrm{Ab}_{65} \mathrm{An}_{25}$ & $\cdots \cdots$ & $\mathrm{Ab}_{65} \mathrm{An}_{35}$ & ......... & $\mathrm{Ab}_{65} \mathrm{An}_{35}$ & ........ \\
\hline Albite................. & $\begin{array}{r}10.0 \\
(71.3)\end{array}$ & $\begin{array}{r}10.5 \\
11.1\end{array}$ & $(12.5)$ & $\begin{array}{r}10.5 \\
16.7\end{array}$ & $\begin{array}{l}13.2 \\
(6.5) \\
(6.7)\end{array}$ & $\begin{array}{r}\cdots \\
5.2 \\
8.3\end{array}$ & $\begin{array}{l}12.4 \\
(6.0) \\
(6.4)\end{array}$ & $\begin{array}{r}5.2 \\
8.3\end{array}$ \\
\hline $\begin{array}{l}\text { Biotite } \ldots . . . . . \\
\text { Hornblende.......... }\end{array}$ & $\begin{array}{r}8.6 \\
.4\end{array}$ & an. & $\begin{array}{r}17.1 \\
7.1\end{array}$ & $\mid \begin{array}{ll}\cdots \\
\cdots \cdots \cdots\end{array}$ & $\begin{array}{r}2.3 \\
.5\end{array}$ & 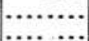 & $\begin{array}{l}4.7 \\
2.6\end{array}$ & ........ \\
\hline $\mathrm{MgSiO}_{3} \ldots \ldots \ldots . . . .$. & & 2.0 & & 7.0 & $\ldots$ & 1.0 & ........ & $\ddot{2.0}$ \\
\hline $\mathrm{FeSiO}_{3} \ldots \ldots \ldots \ldots \ldots$ & ................ & 2.0 & .............. & 5.3 & ............... & .4 & ......... & 1.5 \\
\hline \multirow{2}{*}{ Magnetite ............ } & .1 & .9 & .1 & 2.3 & $\cdots \cdots$ & .2 & .22 & \\
\hline & 100.0 & 100.5 & 100.0 & 97.2 & 99.9 & 100.2 & 100.02 & 99.7 \\
\hline
\end{tabular}

According to the quantitative classification the Nellie Juan granite belongs to Class I (persalane), order 4 (brittanare), rang 2 (toscanase), subrang 2 (dellenose). The rock may then be spoken of as a somewhat phyric granodellenose. The Esther granite belongs to Class II (dosalane), order 4 (austrare), rang 3 (tonalase), and subrang 2 (dopotassic). The rock may be called a granodopotassic tonalase, or in other words, a rather basic biotite-hornblende granite gneiss. The mode is decidedly biotitic. This rock is a little more potassic than the typical tonalite, but it might be called a biotite-orthoclase tonalite. The Cedar Bay granite belongs to Class I (persalane), order 3 (columbare), but - very near to order 4 (brittauare), rang 2 (alsbachase), and subrang 1 (barely

a Cross, Whitman, Iddings, J. P., Pirsson, L. V., and Washington, H. S., Quantitative classification of igneous rocks, 1903 . 
perpotassic). It is therefore a granoperpotassic alsbachase, close to the alaskite group. The small amount of femic minerals gives this rock a normative mode. The Sheep Bay granite is the most acidic of the four granites classified. It belongs to Class I (very persalane), order 3 (columbare), rang 2 (alsbachase), and subrang 2 (mihalose), near subrang 1 (perpotassic). The rock is hence a granomihalose and, like the Cedar Bay granite, is near the alaskite group.

A study of the tables shows that the four granites there listed are of two major types. The first of these is the Esther granite. This granite is very much less acidic than the others. It is also low in potassium or orthoclase, with a correspondingly greater amount of biotite and hornblende (hypersthene in the norm) than the other three. It is nearly a tonalite in composition.

The second group is represented by two divisions, the Nellie Juan granite on the one hand and the Cedar Bay and Sheep Bay granites on the other. The Nellie Juan granite is chemically very close to the dellenite of Brögger and the toscanite of Washington. The other two lack but a small amount of potassium at the expense of lime, magnesia, and iron to become typical alaskites. The last two rocks are very closely alike, differing only in a slight amount of iron and potassium. The Sheep Bay granite is the more femic.

On the other hand, the Esther granite is so different magmatically that there is little doubt of its being different in genesis from its neighbors on the sound. The greater deformation of this granite and the greater anamorphism of near-by sediments suggest that this granite is of greater age than the others. It shows at least that it lies in a more deformed territory.

The relations of the granites to the sedimentary rocks of Prince William Sound are distinctly intrusive, as shown by $(a)$ the lack of basal conglomerates about the granites, $(b)$ the anamorphosed condition of the sediments near the granites, and $(c)$ the presence of dikes leading from the granites into the sediments. After solidification of the granites movements have taken place affecting both the sediments and the granites. This is most notable in the Esther granite. The small size of the granite bosses and the slight degree of anamorphism of the sediments suggest that the granite bosses probably do not enlarge much for a considerable depth. The lack of intense anamorphic changes and the occurrence of porphyritic peripheral phases of the granites, as well as the absence of the complicated aplite and pegmatite dike systems characteristic of deep-seated intrusions, indicate that these granites solidified considerably nearer the surface than is common with granitic intrusions.

The granites, with the possible exception of the Sheep Bay granite, are not associated with the greenstones of the district. The Esther granite is probably the oldest of the granites of the sound. The Sheep Bay granite is intrusive into rocks referred to the Orca group; the other granites cut the Valdez group. The relation of these other granites to the Orca is not known.

\section{ACIDIC DIKES.}

At several localities around Prince William Sound isolated acidic dikes cut the sediments, especially those of the Valdez group. Two 
dikes, one about 3 feet wide, occur on the southeast shore of Harriman Fiord, about 2 miles northeast of its head, and another dike 3 or 4 feet wide is three-fourths of a mile southwest of the Toboggan Glacier. The first two dikes are flesh pink in color and are composed essentially of quartz, orthoclase, plagioclase, and iron carbonate. The carbonate composes about one-fourth of the rock. No suggestion as to the origin of the carbonate, other than that it is probably secondary, can be made from the data at hand. The other dike is a light grayish green, much sericitized aggregate of feldspar and quartz, with a few patches of quartz. The green color is caused by a small amount of chlorite.

Two dikes outcrop at the front of the Barry Glacier on the east side. Both are light grayish green in color; one is finely crystalline and compact; the other is medium grained and granitoid. The finergrained dike contains a few specks of pyrite and some dark-green rodlike forms. These rods (Pl. IX, D) are made of chlorite, epidote, and calcite, but show such distinctive amphibole cross sections that there is no doubt of their having been originally an amphibole. Both dikes are made up principally of quartz, orthoclase, plagioclase, and smaller amounts of calcite. The alteration of the feldspars to muscovite is very marked.

On a little island near the center of the east shore of Unakwik Inlet, is a flinty gray quartz porphyry, intruded parallel to the bedding of the adjacent graywacke. The phenocrysts are of quartz and orthoclase from 1 to 2 millimeters in size. The groundmass is centimillimeter grained, so fine that only quartz is certainly determinable. Crystals of pyrite are scattered through the rock. In some places the porphyry has been fractured and cemented by quartz. Broken phenocrysts of both quartz and feldspar are healed either wholly or in part by material deposited in the same orientation as the broken crystals (Pl. IX, E).

On Unakwik Inlet, north of the mouth of Miners River, a quartz porphyry dike cuts a diorite. The dike has been intensely granulated.

Almost opposite the conglomerate point, on the east side of Unakwik Inlet, are three acidic dikes cutting the bluffs of massive graywacke. The northern two dikes are close together and 20 and 35 feet wide. They are composed of a light-colored, slightly porphyritic medium-grained granite, finer grained at the edges of the dikes than at the center. The major portion of the rock is quartz and orthoclase. In less amount are plagioclase and chlorite. Onefourth mile south of these dikes is a 25 -foot dike of rhyolite, about parallel to the others-that is, about vertical and striking east and west. The phenocrysts of the porphyry are of rounded quartz and feldspar crystals, more rarely biotite, up to 15 millimeters in width. $58668^{\circ}-$ Bull. 443-10 -4 
The groundmass is light greenish gray or brown in color and fel. sitic in appearance. Under the microscope portions of the ground. mass surrounding certain of the quartz phenocrysts have extinction parallel with the quartz. The extinction of the groundmass as a whole is patchy. Certain radial aggregates of spherulitic aspect are present. These facts point to an original glassy groundmass of the rock. Hence it might be termed an aphorhyolite. ${ }^{a}$ Zones of chal. cedonic quartz partly surround some of the quartz phenocrysts. The rock contains brownish inclusions of fine-grained diabase, which appear to be fragments of wall rock. The inclusions examined were either brought up from some diabase below or are very thoroughly crystallized fragments of graywacke.

A dike of porphyritic rhyolite with spherulitic groundmass was noted by Emerson ${ }^{b}$ on the nunatak in the Columbia Glacier.

In $1898 \mathrm{Schrader}^{c}$ mentioned certain gray granitic dikes on the Giant Rocks, Port Valdez, and near the Valdez Glacier. The latter were not visited by this party. The dikes on the Giant Rocks are in a sheared, somewhat schistose graywacke. The specimen from this locality is an orthoclase porphyry in which most of the rock is made up of small orthoclase phenocrysts. Quartz occupies nearly all of the space between the phenocrysts. The peculiar texture of this rock gives the fractured surface a roughness seemingly due to the breaking of the rock between the phenocrysts rather than across them. The weakened, partly granulated quartz is probably the cause of this peculiar fracture.

A dike about 125 feet wide occurs on the east side of the entrance to Valdez Narrows. It is composed mostly of quartz and orthoclase with a little plagioclase. A sulphide, probably pyrite, is distributed rather uniformly through the rock. The sulphide is usually accompanied by a few chlorite flakes.

\section{BASIC INTRUSIVE ROCKS.}

Several occurrences of diorite, diabase, and gabbro in the form of dikes and sills, cutting the graywackes and slates of both the Valdez and the Orca groups, were observed on Prince William Sound. It is probable that these dikes and sills were in part, at least, the feeders of the extensive surface flows of basic lavas during earlier Orca time. A few of the more important occurrences will be described.

\footnotetext{
a Bascom, Florence, The ancient volcanic rocks of South Mountain, Pennsylvania : Bull U. S. Geol. Survey No. 136, 1896, p. 42.

${ }^{6}$ Emerson, B. K., Harriman Alaska Expedition, vol. 4, 1904, p. 25.

- Schrader, F. C., A reconnaissance of a part of Prince William Sound and the Copper River district, Alaska, in 1898: Twentieth Ann. Rept. U. S. Geol. Survey, pt. 7, 1900, p. 409 .
} 
GABBROS.

GABBRO ON ESTHER ISLAND.

On the east side of Esther Island there occurs a gabbro older than the Esther "granite. Here there are the following rocks in the order named, the oldest first: (a) Mica schist, $(b)$ gabbro, $(c)$ granite, $(d)$ aplite and pegmatite. The order of the last two was not determined.

This gabbro exists in several phases. One phase is made up largely of poikilitic crystals of augite inclosing prismoid crystals of labradorite. This feldspar is about the same in all the phases of the gabbro. It is beautifully twinned, according to both the albite and pericline laws. Another phase has in addition to the augite and labradorite a considerable quantity of olivine which is very fresh. About each grain of olivine (Pl. IX, $C$ ) is a zone made up of thousands of acicular colorless crystals of actinolite. Macroscopic examination of the rock reveals the fact that these nodular portions of the rock are more easily weathered parts which cause a pitted weathered surface in this variety of the gabbro.

Van Hise ${ }^{a}$ gives the volume change of this alteration of labradorite to actinolite as minus 7.18 per cent. This, then, was a change under anamorphic conditions. Remembering that the gabbro is older than the granite, and that the granite shows marks of intense deformation, we may conclude that this alteration belongs either to the same period as that in which the granite was deformed or to the period when the granite was intruded. However, no mechanical effects of deformation, such as granulation or slicing, are present in the gabbro.

GABBRO ON LATOUCHE ISLAND.

On the east side of the point at the northeast corner of Latouche Island is a gabbro dike at least 100 feet wide. The rock is intruded into graywackes and slates. It is a little finer grained at the edges than in the middle. It is composed essentially of about equal parts of diallage and andesine-labradorite. Macroscopically the diallage resembles scales of light-green mica scattered through the rock. The microscope shows that the rock has been intensely deformed in the zone of fracture. The feldspars are faulted and broken in a most intricate way. The faults vary from submicroscopic to those of several millimeters displacement. The diallage is in many places twisted, bent, and broken. Both minerals show marked undulatory extinction.

Several small gabbro-pegmatite dikes cut the main dike. The grain of the pegmatite is in places as coarse as 5 centimeters. It is composed of plagioclase, augite in process of uralitization, and smaller amounts of ilmenite.

a Van Hise, C. R., A treatise on metamorphism : Mon. U. S. Geol. Survey, vol, 47, 1904, pp. $310-311$. 
The contact of the gabbro with the sediments is nearly vertical. Graywacke at 2 feet from the contact shows but very little recrystal. lization, though it is somewhat sheared and fractured.

DIABASES.

DIABASE DIKES AT VALDEZ NARROWS.

About $1 \frac{1}{4}$ miles southwest of Entrance Island, on the east side of Valdez Narrows, a 2-foot dike of porphyritic diabase is exposed in the cliff. The strike of the dike is about east and west and it dips $55^{\circ} \mathrm{S}$. The dike is inclosed in graywacke and slate. The porphyritic crystals are probably labradorite. A few small grains of iron sulphide are present. Halfway up the cliff the dike is displaced about its own width by a fault plane.

Just south of the western point on the east side of Valdez Narrows is a basic porphyritic dike, 10 feet wide, cutting hard graywacke and graywacke slate. The dike is a diabase with phenocrysts of plagioclase up to three-fourths of an inch in diameter in the center. The phenocrysts gradually decrease in size toward the edges of the dike and abruptly disappear at about 18 inches from the edge. The outer 18 inches of the dike is very fine grained and compact.

DIABASE IN TATITLEK NARROWS.

Tatitlek Narrows are in a soft slaty band of the Orca group. The slate outcrops on each side of the narrows, but the long slender island in the southern part of the narrows is made up of intrusive diabase. This dike is harder than the surrounding slate and so was left as an elevation in the narrows when the slate was eroded away. The original minerals of the diabase are augite, plagioclase, at least as basic as andesine, ilmenite, and possibly a little quartz. The rock has been somewhat granulated and the minerals are strongly katamorphosed. The augite is altering to hornblende about its margins. The augite and plagioclase are altering to epidote, chlorite, and quartz. Though an appreciable amount of quartz is present, it is probably derived altogether from the alteration of the original minerals. The ilmenite is very largely altered to leucoxene. A few small yellow grains of what is probably a metallic sulphide are scattered very sparsely through the rock.

DIABASE ON UNAKWIK INLET.

At a nickel prospect just north of the mouth of Miners River, on the east side of Unakwik Inlet, is a mass of diabase cutting graywackes and slates. The rock is in several facies, from a mediumgrained diabase to a gabbro-pegmatite. It is composed essentially of augite and labradorite, with considerable amounts of secondary pyr- 
rhotite. The augite is partly uralitized and the labradorite is more or less clouded with tiny particles of alteration products.

GREENSTONES.

In the lower part of the Orca group basic igneous rocks are abundant. (See Pl. II.) They have been altered more or less completely so that they now have a greenish color and are grouped for convenience under the term greenstones. These rocks were originally basic lava flows, basic fragmental volcanic rocks, and basic intrusive bodies. In places shearing has been prominent in these rocks and they are then classified as greenstone schists.

The coarser grained and less altered of these rocks still show plagioclase feldspars and traces of augite. The texture is commonly ophitic and the original rock was thus a diabase. In some places the grain is coarser, the texture approaches the granitoid, and the rock may be termed a gabbro. Commonly, however, the rocks are highly altered and the augite is changed to hornblende. Where shearing stresses have been prominent, chlorite as well as hornblende is developed. In many localities alteration has gone so far that the original texture and minerals are not recognizable.

A very large part of the greenstones of the Orca group are surface flows. Their mode of occurrence has been described under the heading "Galena Bay" in the special descriptions of the Orca group. Many of these surface flows are ellipsoidal in character-that is, the flows contain many more or less ellipsoidal masses which vary from a few inches to 10 feet in diameter. These ellipsoids in many places make up almost the entire flow. Between the individual ellipsoids is a softer, greenish, locally schistose material whose original character is not clear. In shape some of the ellipsoids are almost spherical; but they are more commonly more or less flattened in a plane parallel to the dip of the flows. In some ellipsoids this flattening is probably due to pressure after the rock was covered with other flows or with sediments; in others the flattening appears to be due to the pressure of one ellipsoid on another before they had completely solidified. Still other ellipsoids are rather irregular in shape, but are bounded by curving planes. Some ellipsoids show a radial structure (Pl. VIII, $B$ ).

The ellipsoidal greenstones are common throughout the lower part of the Orca group. Some of the most characteristic exposures occur both north and south of the entrance to Galena Bay and are shown on Plate VIII. In the more mountainous parts of the greenstone areas, as about Copper Mountain and on Knight Island, the ellipsoidal greenstones are not so common, but even in these places traces of this structure are recognizable here and there.

The ellipsoidal structure in basic lava flows is a not uncommon feature and has been described from several places. It is generally 
thought that this structure occurs in submarine flows, or at least in flows which have entered water. The Prince William Sound ellipsoidal greenstones are very similar to the Archean Ely greenstone of the Vermilion iron range in Minnesota, descriptions of which have been written by Winchell ${ }^{a}$ and by Clements. ${ }^{b}$

\section{ECONOMIC GEOLOGY.}

COPPER.

\section{HISTORICAL STATEMENT.}

Copper is the principal metallic substance found on Prince William Sound, and, in fact, the only one of which shipments of economic importance have been made.

There are reports that copper prospecting was undertaken during the Russian occupation of Alaska, one specific place being in the mountains of the western part of Hinchinbrook Island, both north and south of Nuchek. Sporadic prospecting is said to have been carried on in the years between the end of the Russian occupation and 1897. Definite information concerning this early prospecting is, however, not at hand.

The recent period of the search for copper on the shores of the sound dates from the staking of the Gladhaugh claim on the east side of Virgin Bay in 1897. This claim developed into the Ellamar mine. The Bonanza mine on Latouche Island was staked later in the same year. From that time to the present prospecting for copper has been active, especially from 1903 to 1907 .

There are two mines which have made regular shipments for several years. These are the Ellamar mine, at Ellamar, and the Bonanza mine, on Latouche Island. Shipments of several hundred tons of ore have been made from certain other properties, as the Knights Island Consolidated Copper Company, locally known as the Hubbard \& Elliott Company, on Knight Island; the Latouche Copper Mining Company, on Latouche Island; the Reynolds-Alaska Development Company, on Boulder Bay and on Latouche Island; the Standard Copper Mines Company, on Landlocked Bay; and the Three Man Mining Company, on Landlocked Bay. Small trial shipments have been made from other properties.

The mineral production of the district for 1900 to 1908 is shown in the following table. The production before 1900 was small. Unfortunately, the figures for the years previous to 1905 are not very reliable, for it was not until that year that the Survey began the collection of statistics for Alaska directly from the producers.

\footnotetext{
- Winchell, N. H., The Kawishhiwin agglomerate at Ely, Minn. : Am. Geologist, vol. 9, 1892, pp. $359-368$.

${ }^{\circ}$ Clements, J. Morgan, The Vermilion iron-bearing district of Minnesota: Mon. U. S. Geol. Survey, vol. 45, 1903, pp. 144-150.
} 
Mineral production of Prince William Sound, 1900-1908.

\begin{tabular}{|c|c|c|c|c|c|c|c|}
\hline \multirow{2}{*}{ Year. } & \multicolumn{2}{|c|}{ Silver. $a$} & \multicolumn{2}{|c|}{ Gold. $a$} & \multicolumn{2}{|c|}{ Copper. } & \multirow{2}{*}{$\begin{array}{l}\text { Percent- } \\
\text { age of } \\
\text { copper } \\
\text { per ton. }\end{array}$} \\
\hline & Ounces. & Value. & Ounces. & Value. & Pounds. & Value. & \\
\hline \multirow{7}{*}{ 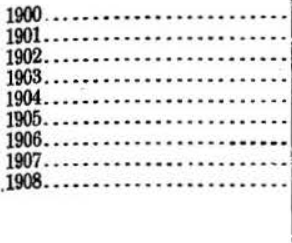 } & \multirow{7}{*}{$\begin{array}{l}5,307 \\
7,900 \\
8,954\end{array}$} & \multirow{7}{*}{$\begin{array}{r}\$ 3,555 \\
5,214 \\
4,745\end{array}$} & & & 250,000 & $\$ 40,000$ & \\
\hline & & & . & ............. & $\begin{array}{r}360,000 \\
1.200,000\end{array}$ & $\begin{array}{r}41,000 \\
\end{array}$ & 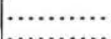 \\
\hline & & & …….......... & n............... & $2,043,586$ & 275,676 & ............... \\
\hline & & & & & $1,580,379$ & $\begin{array}{l}246,539 \\
407,082\end{array}$ & $\dddot{4}$ \\
\hline & & & \multirow{3}{*}{$\begin{array}{r}870.75 \\
1,156.09 \\
56.74\end{array}$} & \multirow{3}{*}{$\begin{array}{r}\$ 18,000 \\
23,899 \\
1,173\end{array}$} & $\begin{array}{l}2,109,232 \\
1,549,972\end{array}$ & $\begin{array}{l}407,082 \\
309,994\end{array}$ & $\begin{array}{l}4.1 \\
4.4\end{array}$ \\
\hline & & & & & $1,324,963$ & 174,895 & 4.9 \\
\hline & & & & & $10,418,132$ & $1,651,186$ & 4.4 \\
\hline
\end{tabular}

a Statistics for gold and silver output are available only since 1905 .

ORE MINERALS.

Chalcopyrite is by all means the most important copper-bearing mineral on the sound. It is present in practically all the mines and prospects and is the mineral which forms the ore of all the large shipments. It occurs in rather finely granular form and its brightyellow color makes it easy of recognition. In some of it the grain is very fine indeed.

The chalcopyrite is in general intimately mixed with pyrrhotite, which in itself probably bears a little copper sulphide as an impurity. These two minerals, chalcopyrite and pyrrhotite, are practically everywhere present, and the relative proportions of the two vary greatly, not only in adjoining deposits but in the same deposit. It is a common feature in any one vein to find abrupt variations from point to point in the abundance of these two minerals, at one place the vein being almost entirely pyrrhotite and close by almost entirely chalcopyrite.

With the two minerals just mentioned, but occurring in much less abundance, is pyrite, which also probably carries a little copper. The pyrite is usually granular in form, and locally the grain is very fine, as at the Duchess tunnel, near Horseshoe Bay, on Latouche Island. In places pyrite occurs in crystals from a quarter of an inch to nearly an inch in diameter; such crystals are especially noticeable at the Bonanza mine, where they exist in the form of pentagonal dodecahedrons which have their crystal boundaries sharply marked and are included in almost solid chalcopyrite. Some of the crystals of pyrite at the Bonanza mine are surrounded by a thin film of quartz, or of quartz mixed with a small amount of chalcopyrite. These crystals of pyrite also occur rarely at the Ellamar mine.

Secondary (surface) copper minerals are not of great importance, as weathering has extended only a small distance from the surface. Such minerals are malachite, which occurs as green stains in very 
many localities; azurite, which is rare; covellite, which has been found at the Bonanza mine; and native copper, which has been found at the prospects of the Three Man Mining Company on Landlocked Bay, and also at the Bonanza mine, where it is now being deposited as a cement to gravels in a stream bed close to the mine. An indistinct, powdery, black copper mineral, probably melaconite, occurs in small quantity also at the Bonanza mine.

At the prospects of the Cordova Copper Company, near Orca, occur copper minerals partly different from those noted above. Here are found not only chalcopyrite, but also bornite, chalcocite, native copper, cuprite, and malachite. The last two are clearly formed by surface alteration.

Other metallic minerals associated with the ores are galena, sphalerite, and magnetite. Galena occurs in small amounts at some of the prospects about Landlocked Bay, at the Bonanza minê, and in a few other places. - Sphalerite also occurs at Landlocked Bay and at the Bonanza mine, but is more abundant in certain prospects on Louis Bay and on Herring Bay in the northern part of Knight Island. It also occurs at the Ellamar mine.

The nonmetallic minerals associated with the ores are quartz, calcite, epidote, chlorite, and other alteration minerals. Quartz is by far the most common.

As these minerals have not usually been deposited in open cavities, but occur as impregnations and as replacements of the country rock, there is in many places little to show what their order of deposition has been. The three common metallic sulphides, chalcopyrite, pyrrhotite, and pyrite, usually appear to be simultaneous in origin. Galena and sphalerite also occur with these three, but are in places apparently earlier in date. Much of the quartz is intimately associated with the minerals just mentioned, and much of it is distinctly later than those minerals. Calcite is usually later than the others. Here and there a few small veins of chalcopyrite and of pyrrhotite are seen to be later than the main deposits, but these are exceptional. In one place a small quartz vein had its center filled with pyrrhotite, the quartz projecting into this mineral in crystal form, and one small vein of calcite was noted where pyrrhotite formed the center.

ORE BODIES.

GENERAL DESCRIPTION.

The usual occurrence of the copper deposits is in zones along which there has been fracturing of the country rock. Most generally this fracturing has gone so far that shearing has taken place, and the ore deposits thus commonly occur in shear zones. In these zones the country rock is usually schistose. Deposits of this character are common in the vicinity of Copper Mountain, where the shear zones are well 
developed. They have been well exposed at several points east of this mountain, especially at the claims of the Three Man Mining Company on Landlocked Bay. Along these zones there has been mineralization of the rock, chalcopyrite, and the associated sulphides, pyrrhotite, and pyrite, having been deposited as impregnations and as replacements of the country rock.

Within a single shear zone it is frequently possible to distinguish two parts-first, a more or less solid layer of metallic sulphides, and second, the rest of the zone, which has been only partly impregnated with these sulphides. The solid layer is the most conspicuous and important part of these zones. In some places this layer occupies the whole of a shear zone, but very commonly the other part of the zone is present. This layer of nearly solid sulphides is as a rule sharply marked off from the rest of the zone, which holds a more constant width, while the sulphide layer has a tendency to swell and pinch, in places disappearing entirely. The thickness of the sulphide layer varies from a film up to several feet, but at most of the prospects thicknesses of over 5 feet are uncommon, and such thicknesses are as a rule not of great extent. The ore in such layers ranges from almost pure pyrrhotite to nearly pure chalcopyrite. Pyrite occurs, but not as commonly as pyrrhotite. Assays of these layers show percentages of copper running up to 25 or 28 , but the average is considerably lower than this.

The sheared rock outside of the sulphide layer varies decidedly in width and in its copper content. In some places there are several feet of this rock, in others the thickness is 40 feet or more, and in a few such places there is no sharp boundary between the sheared rock and the unsheared country rock, or the sheared zone contains horses of solid rock. The copper content of this sheared rock is in some places practically nothing and in others runs up to a few per cent. So far as developed there are no considerable thicknesses of this rock which run over 4 per cent of copper.

The country rock of these zones is mainly greenstone, although some slate and graywacke are present, and in some places the shear zones follow closely the contact of these sediments with the greenstone. An exception to this statement should be made for the deposits on Latouche Island and on the south side of Fidalgo Bay, where the country rock is slate and graywacke.

In a few localities there are rather sharply defined veins filled with quartz, pyrrhotite, pyrite, and chalcopyrite. One of these was seen on Glacier Island and one on the northwest flank of Copper Mountain. In such localities there was apparently an open cavity, which was later filled with the minerals last named, but even here there is no distinct banding to the veins and the minerals are of one general date. It is improbable that there were ever any large cavi- 
ties in the shear zones. The ore minerals were deposited in part along the shearing planes, but especially in the sheared rock, both by impregnation and by replacement.

The two largest ore deposits, those of the Ellamar and Bonanza mines, differ from the shear zones above described in some respects. The Ellamar ore body is a lens-shaped mass, whose maximum horizontal axis is 190 feet and minimum axis 80 feet. Careful studies of this ore body have not been made, but it seems probable that it is of the same general nature as the solid sulphide layers so common in the usual shear zones. Another lens-shaped body of this character occurs at the Duchess tunnel on Latouche Island. The Bonanza mine is apparently along one of these same shear zones, but the movement here has resulted in fracturing rather than shearing, and the country rock is in large amount a very fine grained, hard, flinty rock.

On Knight Island there are at two places deposits of different character from those described above. One of these is at the Harvey prospect, north of the west arm of Mummy Bay, and the other is at the prospect of the Knight Island Copper Company, east of Barnes Cove of Drier Bay. This has been described by Sidney Paige ${ }^{a}$ At these places the country rock is a fairly coarse grained diabase which has been impregnated by pyrrhotite and chalcopyrite.

In the vicinity of Orca are some prospects that are of still a different type from those described above. The country rock is a much crushed reddish amygdaloidal basalt, with irregular stringers of epidotized rock. These stringers are of all widths up to 2 feet, and though some of them have a veinlike form, striking in an eastnortheast direction and standing vertically, most of them show no common direction of elongation and pinch out within short distances. With the epidote is quartz. The ore, which is native copper, chalcopyrite, bornite, and chalcocite, occurs associated with and in the epidote-quartz stringers, although in places it is associated with the nonepidotized country rock. The country rock, its alteration to epidote-quartz masses, and the occurrence of copper ore within these masses all resemble conditions in parts of the Lake Superior copper district.

Weathering has extended to only a short distance, commonly only a few feet or even a few inches, below the surface in the glaciated parts of the sound, and all the copper prospects examined are in glaciated territory. There has thus been very little surface alteration of the ore deposits and consequently little recent secondary enrichment.

As is customary in many mining districts, long tunnels have been driven into the mountains with the hope of cutting at some depth ore bodies which outcrop at the surface. In several such tunnels,

${ }^{a}$ Bull. U. S. Geol. Survey No. 284, 1906, p. 85. 
especially where they cross the ore zones at 100 feet or more below the surface outcrops, the zones are found to be thinner and much lower in copper content. In fact, in some places it is almost impossible to recognize in the tunnels shear zones which are prominent and carry a considerable copper content at the surface. Of course there are many prospects where no information is available concerning the character of the ore bodies many feet below the surface.

\section{ORIGIN OF THE ORE BODIES.}

Information concerning the copper deposits of Prince William Sound is far from complete. There are only two producing mines, and to only one of these have the writers had free access. At the same time a considerable body of information concerning these ore deposits is at hand, and this, coupled with the resemblance of these to other, better-known deposits, makes it possible to outline a feasible explanation for the origin of the copper deposits of the sound.

The copper veins and ore bodies are found either in or in close connection with basic igneous rocks. An exception to this statement might be made for the deposits on Latouche Island, but even here such rocks are known at both the northeast and the south ends of the island, and a highly sheared, probably igneous rock occurs on the property of the Latouche Copper Mining Company a short distance northeast of the Bonanza mine. The ores occur in zones along which there has been fracturing or shearing or both. The ore minerals are themselves of more recent date than most of this fracturing and shearing, which has taken place during or after the last folding of the rocks of the Orca group, and consequently the ore deposits are of considerably later origin than most of the basic igneous rocks of the district, which are contemporaneous with the Orca sediments and have been severely affected by the above-mentioned dynamic action. Other basic rocks later than or contemporary with the fracturing and shearing are not always clearly recognizable. Yet a few diabase dikes are known which do not seem to have been affected by dynamic metamorphism. A dike of this character forms the long island on the southwest side of Tatitlek Narrows, and this dike or another of the same nature may have played an important part in the formation of the ore body of the Ellamar mine. In fact, fragments of coarse diabase occur on the beach near this mine, and an earlier report speaks of a diabase dike at the mine. ${ }^{a}$ A few small unsheared diabase dikes, cutting the sediments and igneous rocks of the Orca group, have been noted, and it is possible that the gabbro mass on the northeast end of Latouche Island may be of later date than the folding of the Orca group. There is thus fairly definite proof of the intrusion of at least small masses of igneous rocks at a date later than the for-

${ }^{a}$ Harriman Alaska Expedition, vol. 4, 1904, p. 25. 
mation and folding of the rocks in which the ore deposits lie, but the relation of these later igneous rocks to the shearing and fracturing and to the ore deposits themselves is not definitely known.

The minerals in the ore bodies are chiefly pyrrhotite and chalcopyrite. With these in places are quartz, pyrite, and sphalerite, and in at least one vein magnetite occurs. As a rule the ore minerals are intimately intergrown and are thus apparently of contemporaneous origin.

The ore bodies occur in more or less irregular elongated lenses which widen and narrow as they are traced along the strike and some of which pinch out entirely. The information at hand shows that they vary similarly with depth, although detailed knowledge of most of the deposits is not available.

The district has been recently glaciated and the present groundwater level is close to the surface. The weathered parts of the veins, if there were such, have been removed by glaciation and recent weathering has extended a few inches or a few feet below the surface. There is thus lacking a considerable leached zone in the upper part of these veins.

The facts stated above lead to the conclusion that the ore bodies were probably formed under somewhat deep-seated conditions and probably in connection with the intrusion of basic igneous rocks.

An alternative hypothesis for the origin of at least some of these ore deposits would suggest a primary origin, somewhat similar to that outlined above, followed by secondary enrichment of the upper parts of the veins by downward percolating surface waters before the last glaciation of the district. During glaciation the upper leached parts of the veins were removed, and there are thus left to-day the lower parts of the enriched portions, which grade downward into the leaner nonenriched primary deposits. Such an explanation may apply to the ore at some of the prospects near Orca, where there are considerably larger amounts than usual of secondary minerals, but no information is at hand concerning the change in the character of these deposits with depth. A similar explanation may apply to the deposit at the Bonanza mine, where the ore body lies on and just below a steep slope, a favorable topographic situation for a secondarily enriched deposit, and the ore itself contains much more chalcopyrite and much less pyrrhotite than usual; in fact, much of the pyrrhotite occurs in the bands of practically solid sulphides (mentioned in the description of the mine, p. 66) and chalcopyrite is less abundant in the lower level of the mine than it is nearer the surface. Since glaciation there has been surface leaching (and probable enrichment) of the deposit, as is shown (1) by gossan a few feet in thickness, (2) by a zone of black sulphides a few inches in thickness 
above the main ore, and (3) by waters which are carrying copper in solution and are in one place depositing native copper and malachite.

SPECIAL DESCRIPTIONS.

There are nearly 200 copper prospects about the shores of Prince William Sound. At many of these practically no work has been done, but at many others there has been more or less stripping, digging of test pits, and tunneling. Most of the prospects on which work has been done have been visited during the progress of this investigation. The following descriptions are confined to places where considerable development work has been carried on or where features of special interest occur.

\section{GALENA BAY.}

Several prospects are located on the north slopes of Copper Mountain, south of the head of Galena Bay. At one of these localities, Vesuvius Valley, there has been much activity, the principal work being on one long tunnel. This was worked by the Prince William Sound Mining Company and had a length of over 300 feet in 1905. This property was later taken over by the Galena Bay Mining Company, which constructed a dam that gives a 52 -foot head of water and installed an electric power plant. The electric power is transmitted about 3 miles southward and used to run an air compressor at the mouth of the above-mentioned tunnel, which in August, 1908, had reached a length of over 1,500 feet. The mouth of the tunnel is about 750 feet above sea level, and it is being driven in to intersect a large shear zone which outcrops some 800 feet above. It is expected that when the ore zone is reached an aerial wire-rope tramway will be installed from the tunnel to tide water, a distance of about 18,000 feet. The material for this tramway was on the ground in 1908 .

In 1909 this tunnel was extended to a length of 1,800 feet and some diamond drilling was done from the breast of the tunnel. An ore body 30 feet in thickness and 200 feet from the breast of the tunnel, lying probably in the shear zone outcropping above, was penetrated by the drills. Further drilling was done on the Sunnyside claim, about 3,000 feet from the mouth of this tunnel, on the west side of Vesuvius Valley. ${ }^{a}$

ELLAMAR.

The Ellamar mine is located at the town of Ellamar, on the east shore of Virgin Bay. (See Pl. X, A.) The writer was permitted to enter the mine only in September, 1905, and the accompanying 
map (fig. 4) is of the workings at that date. This property was staked in 1897 and has been making regular shipments of copper ore for several years. The mine has been opened to a depth of 600 feet. The ore body outcrops at the surface and is uncovered at low tide. The form of the ore body is lens-shaped, with its major axis strik-

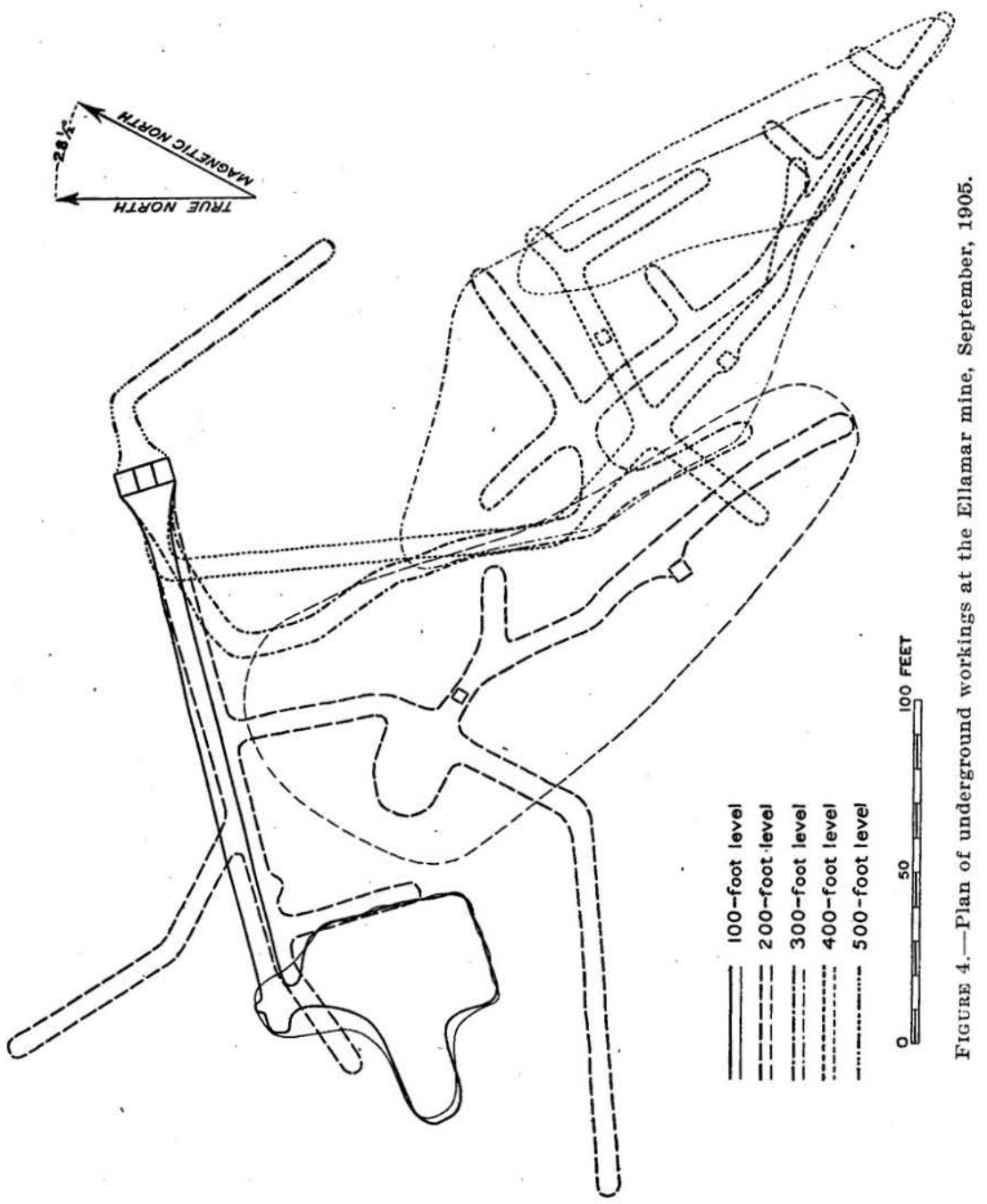

ing N. $35^{\circ}$ W. The dip is $80^{\circ}$ NE. to $90^{\circ}$, and there is a pitch of about $35^{\circ}$ toward the southeast. The ore body reaches its largest size on the 200-foot level, where it has a length of 190 feet and a width of 80 feet. (See fig. 4.) The ore body consists of chalcopyrite, pyrite, pyrrhotite, and country rock. Commonly the rock is lacking and the ore body is practically solid sulphides. The high- 


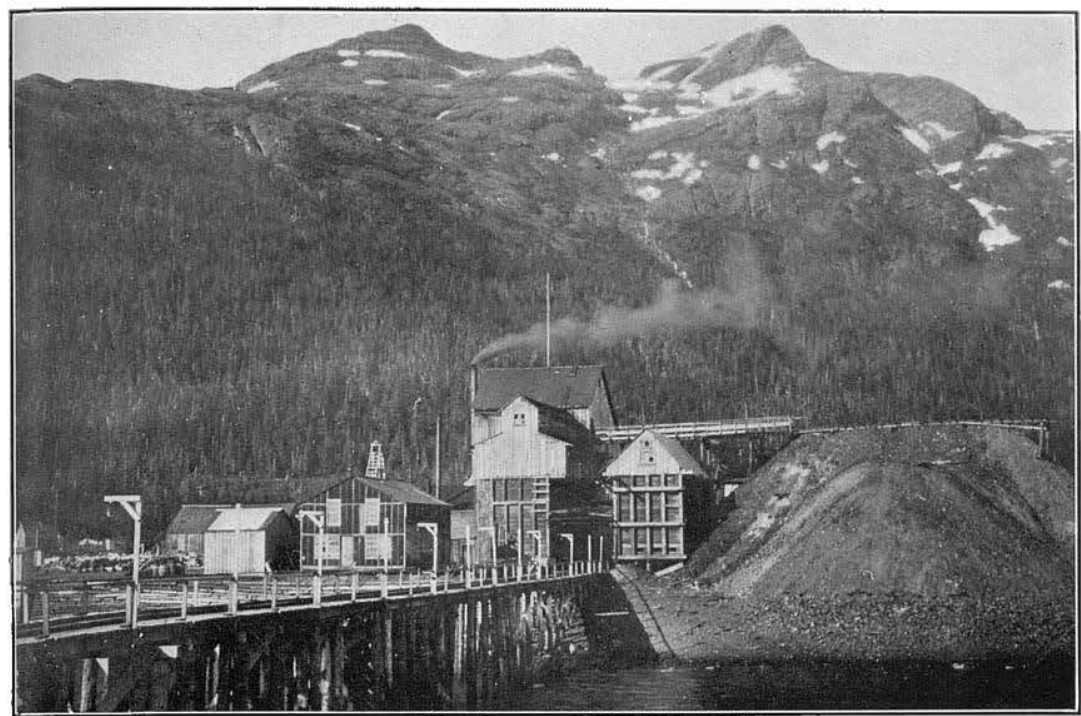

A. ElLAMAR Mine at ELLAMAR, JULY, 1908

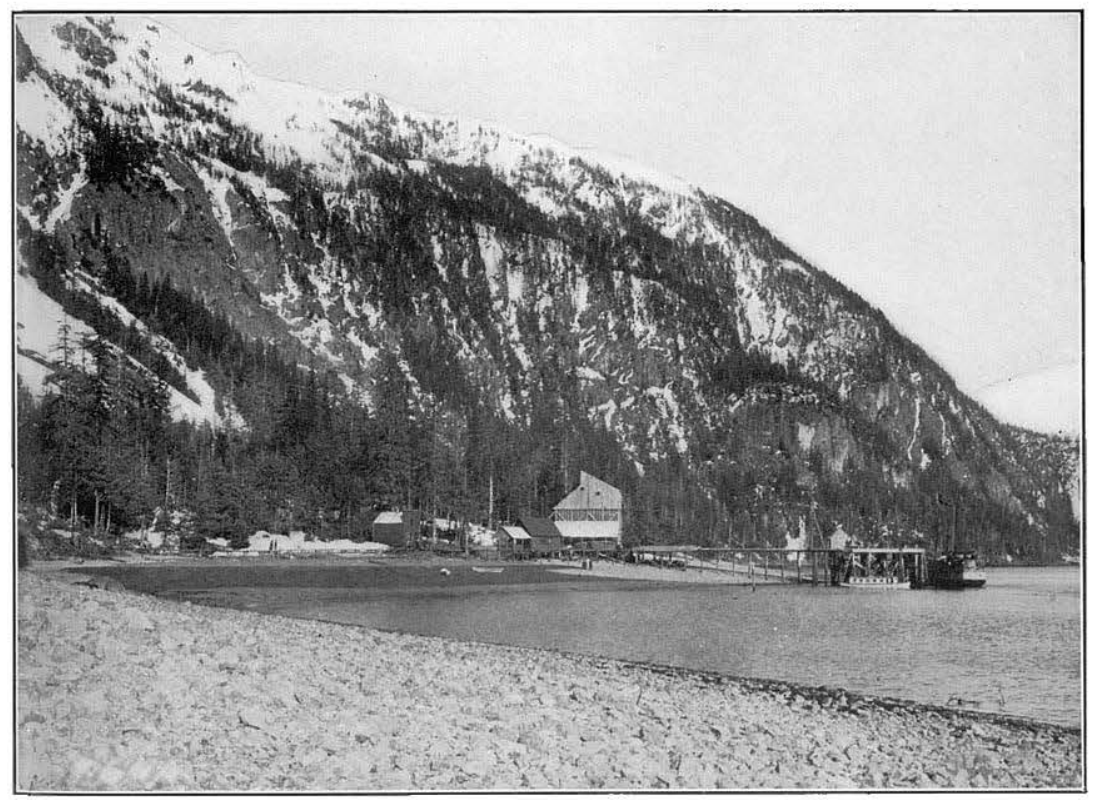

3. DOCK AND ORE BUNKERS OF THE STANDARD COPPER MINES COMPANY ON LANDLOCKED BAY.

Photograph by Cantwell. 

est-grade ore is in general confined to a poorly defined ore shoot which forms the middle of the foot wall half of the ore body. The country rock is soft black slate, with a few bands of graywacke and black limestone. The strike of the rocks is in general parallel to that of the ore body. Diabase bowlders, evidently from the rock in place close at hand, occur 150 feet north of the mine and a diabase dike has been reported from this mine. ${ }^{a}$ The black slate is much fissured and crushed and the fragments are commonly slickensided. The ore is in the main massive and not fractured, although there are some small cracks which have been filled by calcite and quartz.

During the summer of 1909 and part of 1910 a horseshoe-shaped coffer dam, 400 feet in length and 20 feet above low tide, was under construction near the low-tide line at the Ellamar mine, the object of the dam being to exclude the high tide from the outcrop of the ore body so that the part of this body between the 100 -foot level and the surface can be removed.

\section{BOULDER BAY.}

Boulder Bay lies just west of Copper Mountain and much pros. pecting has been carried on near its head. The chief work has been done by the Reynolds-Alaska Development Company, which has about 20 claims east of the head of the bay. The property is developed by a wharf, electric plant, air compresor, office and bunk houses, supply house, superintendent's house, and about 2,100 feet of drift in the main tunnel and 200 feet of drift in a smaller opening. The main tunnel is at tide water and is composed of a rather complicated system of crosscuts, winzes, and raises, driven through interbedded greenstones, slates, and graywackes. It is lighted by electricity on the main drifts. A few veins of chalcopyrite were encountered. About 150 feet above this system is the smaller tunnel mentioned above. It is in greenstone having locally disseminated chalcopyrite and small veins of the same mineral also occur. Just to the right of the main adit is an excavation, from which, it was reported, several tons of shipping ore were procured. Several hundred tons of ore are said to have been shipped from this property. Some of this ore came from two large bowlders, composed chiefly of iron and copper sulphides, which were found on the beach at the mouth of the main tunnel.

\section{LANDLOCKED BAY.}

Much prospecting has been done about both the south and the north shores of this bay. The most extensive work has been done on the north shore by two companies, the Standard Copper Mines Company and the Three Man' Mining Company. 
STANDARD COPPER MINES COMPANY.

The Standard company has constructed a wharf, ore bunkers, office, etc., on the north side of Landlocked Bay. (See Pl. X, B.) From the wharf a wire-rope aerial tramway, 2,526 feet in length, leads up the south side of Copper Mountain. Above this tramway is another, 923 feet long, leading to the mouth of a tunnel some 2,000 feet above sea level. This tunnel is run to intercept three ore-bearing zones that outcrop on the mountain above. In August, 1908, the tunnel had reached a length of 420 feet. The lowest ore zone is intersected near the mouth of the tunnel, and from this several hundred tons of ore have been mined, most of which has been shipped. The second zone is not clearly cut by the tunnel, and at the time of visit the tunnel was thought to be entering the third zone. These zones are schistose areas in the greenstone of Copper Mountain and they carry lens-shaped bodies of ore. The property has also been developed by several smaller tunnels and strippings.

THREE MAN MINING COMPANY.

The Three Man Company has a considerable number of claims, locally known as the Dickey claims, about the head of Landlocked Bay. Most of the development work has been done on the north side of the bay, where numerous tunnels have been run, strippings made, and several veins revealed. Much of the work has been done by drifting along the veins or by short crosscuts which intersect the veins. The veins are in greenstone, graywacke, and slate, and consist of schistose shear zones carrying chalcopyrite and pyrrhotite. Several of these shear zones give good examples of the two parts into which some such zones are divided-that is, there is a central layer of nearly solid sulphides, outside of which the ore is disseminated through the sheared rock. Trial shipments have been made from these claims and more ore is now ready for shipment. Most of the work has, however, been devoted to opening the veins and not to getting out ore for shipment.

FIDALGO BAY.

The prospects on Fidalgo Bay were discovered at a later date than most of the other prospects on the sound, and these discoveries have considerably extended the territory in which the search for copper is actively progressing.

WHALEN AND NELSON PROSPECT.

On the south side of Fidalgo Bay, 7 miles east of Fish Bay, is a smaller bay called Whalen Bay. Two miles east of the head of Whalen Bay and about 700 feet above sea level are some strippings 
and a small tunnel. The country rock is a hard black to greenish slate and the ore is a hard band of nonslaty rock containing irregular stringers and disseminated grains of chalcopyrite and pyrrhotite. This band of ore is 2 to 4 feet in thickness where examined and is reported to have been uncovered at intervals for a considerable distance, in some places being 12 feet thick.

FIDALGO MINING COMPANY.

The prospect owned by the Fidalgo Mining Company is located on the south side of Fidalgo Bay, a mile southwest of Whalen Bay. Twenty-four claims, locally known as Blakney's prospect, have been staked. A supply house at the beach, a bunk house, and a tunnel are the main developments on this property. This tunnel is 2,800 feet from the shore and 450 feet in length. It follows a well-defined shear zone. Two rather definite lens-shaped ore shoots, each about 5 by 50 feet in cross section, have been struck at 200 and 300 feet from the entrance, and many small stringers of ore, which is chiefly chalcopyrite, occur throughout the tunnel. A small crosscut beyond the second ore shoot shows a 20 -inch vein of nearly solid chalcopyrite. Several small strippings have been made on the shear zone, which has been traced for about 3,000 feet. Some ore is ready for shipment.

FIDALGO ALASKA COPPER COMPANY.

The property of the Fidalgo Alaska Copper Company is on the south side of Fidalgo Bay, south of Fish Bay and half a mile east of Irish Cove. The main development work has been on and near the top of a hill, which rises about 1,000 feet above sea level. A large amount of stripping has been done, and several short tunnels and two longer ones have been run. The main tunnel has over 400 feet of workings. The country rock is a hard black to gray slate, with a little graywacke. The ore, which is chalcopyrite with a little pyrite, is in hard, fractured zones in the country rock and occurs as a cement to the fractures, as irregular stringers, as disseminated grains, and as larger replacements of the country rock. These fractured zones are irregular in size and extent and some of them have proved not to continue far. Developments have not yet shown how extensive others of these zones are. Altogether there is a considerable amount of ore exposed in the strippings and in the tunnels, and some ore is ready for shipment.

\section{LATOUCHE ISLAND.}

BONANZA MINE.

A trial shipment of about a ton of ore was made from the Bonanza mine in 1899. Other small shipments followed and in 1903 over a hundred tons was shipped. Regular shipments began in 1904 and $58668^{\circ}-$ Bull. $443-10-5$ 
have continued since. A dock, ore bunkers, an office, and mess and bunk houses have been constructed (Pl. XI, $B$ ), and two tramways have been built from the dock to the mine, about half a mile distant. The mine is in the main a large open hill face (Pl. XI, $A$ ), from which the ore is quarried and run down to two tunnels, one 30 and the other 120 feet below the quarry floor. The ore is trammed from these tunnels to the dock. Aside from the open quarry about 4,000 feet of tunneling had been done on the property up to the end of 1909. The shape and size of the quarry is shown in figure 5, and the two tunnels in figure 6 .

The country rocks at the Bonanza mine are slates and graywackes (see Pl. XII and fig. 3), the slates being more common west of the mine and the graywackes more common in the bold hill east of the mine. Some of the graywackes are slightly calcareous and small

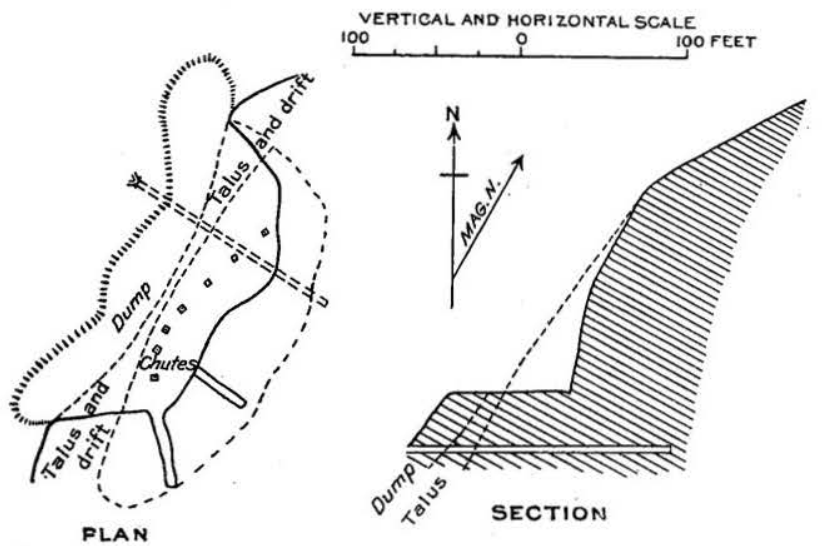

Figure 5.-Bonanza mine, Latouche Island. $a$, Sketch plan of the quarry; $b$, sketch section of the quarry.

calcite veins occur in a few places. At the mine itself the country rock is in very large part a white-weathering, very fine grained, dense, hard greenish flinty rock. This rock is composed, as seen under the microscope, of quartz and a chloritic mineral (probably ripidolite) with small amounts of a fresh acidic plagioclase. A chemical analysis of this flinty rock gave the results shown in the accompanying table. In this analysis the ferrous iron, magnesia, water above $100^{\circ}$, and most of the alumina are to be referred to the chloritic mineral; the feldspar is small in amount; and the main part of the rock is quartz. No certainly clastic grains are seen in the sections, and in the field no banding or bedding was noted in this flinty rock, and its relation to the adjacent slates and graywackes was not clear. It has somewhat the appearance of an igneous rock, but its chemical composition is not similar to that of any known igneous rock. 


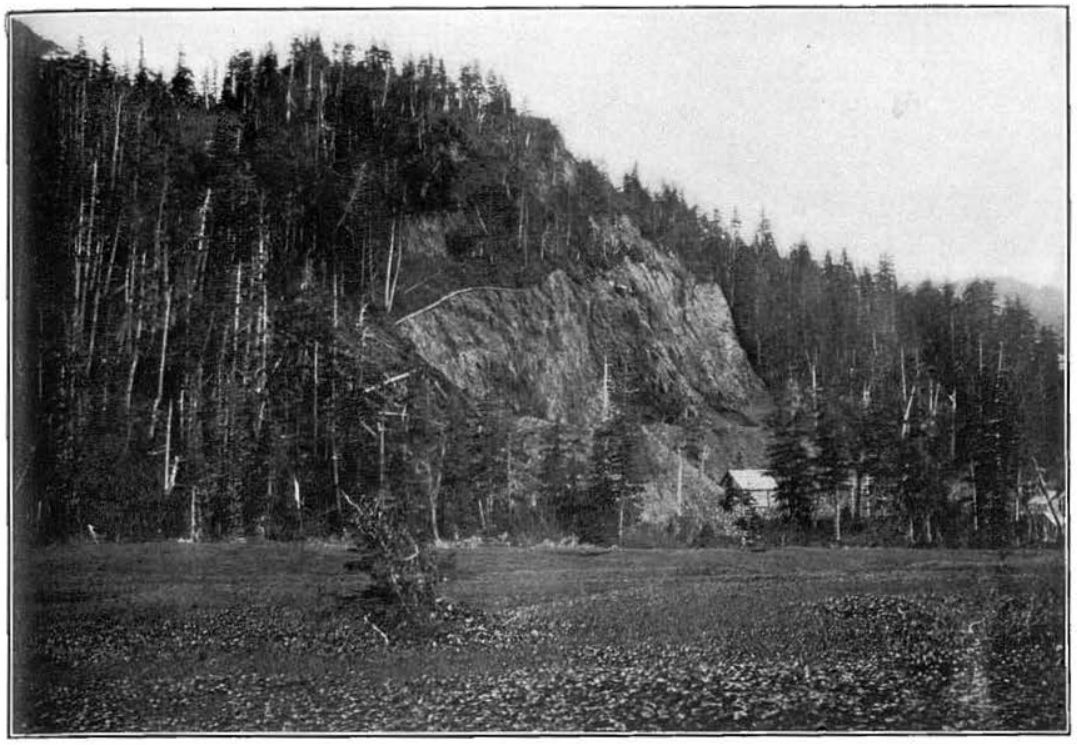

A. QUARRY FACE OF THE BONANZA MINE ON LATOUCHE ISLAND, JULY, 1908.

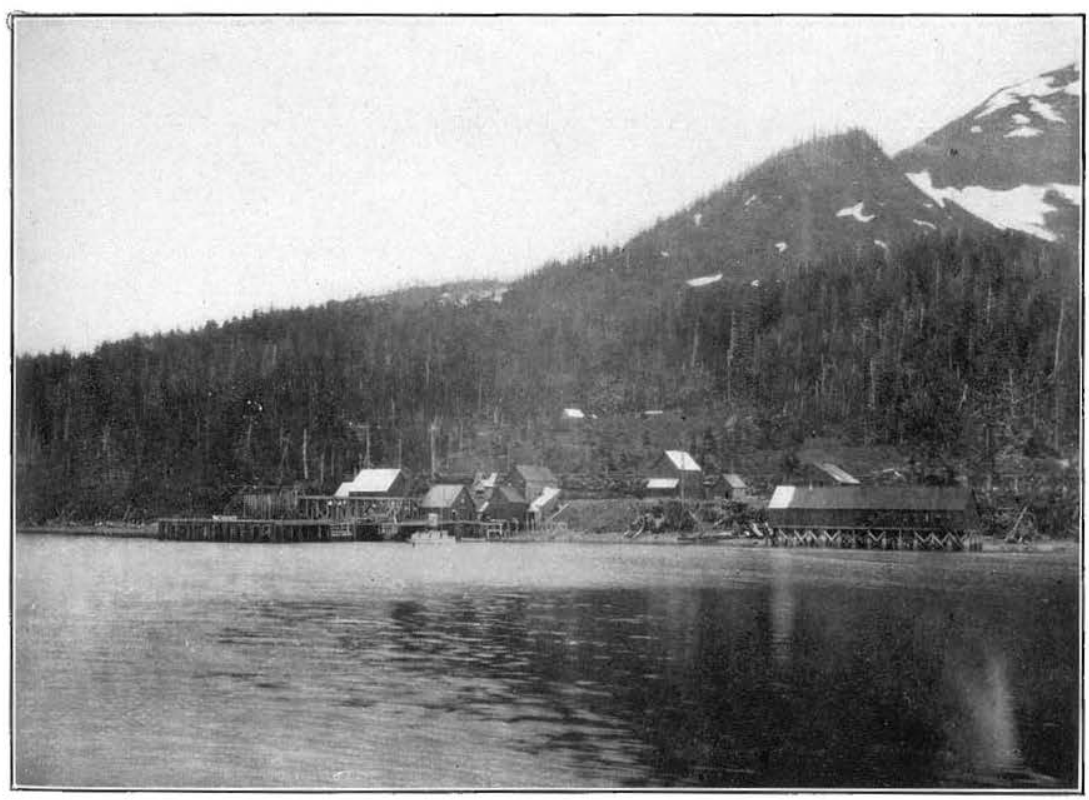

B. DOCK AND ORE BUNKERS OF THE BONANZA MINE ON LATOUCHE ISLAND, JULY, 1908 



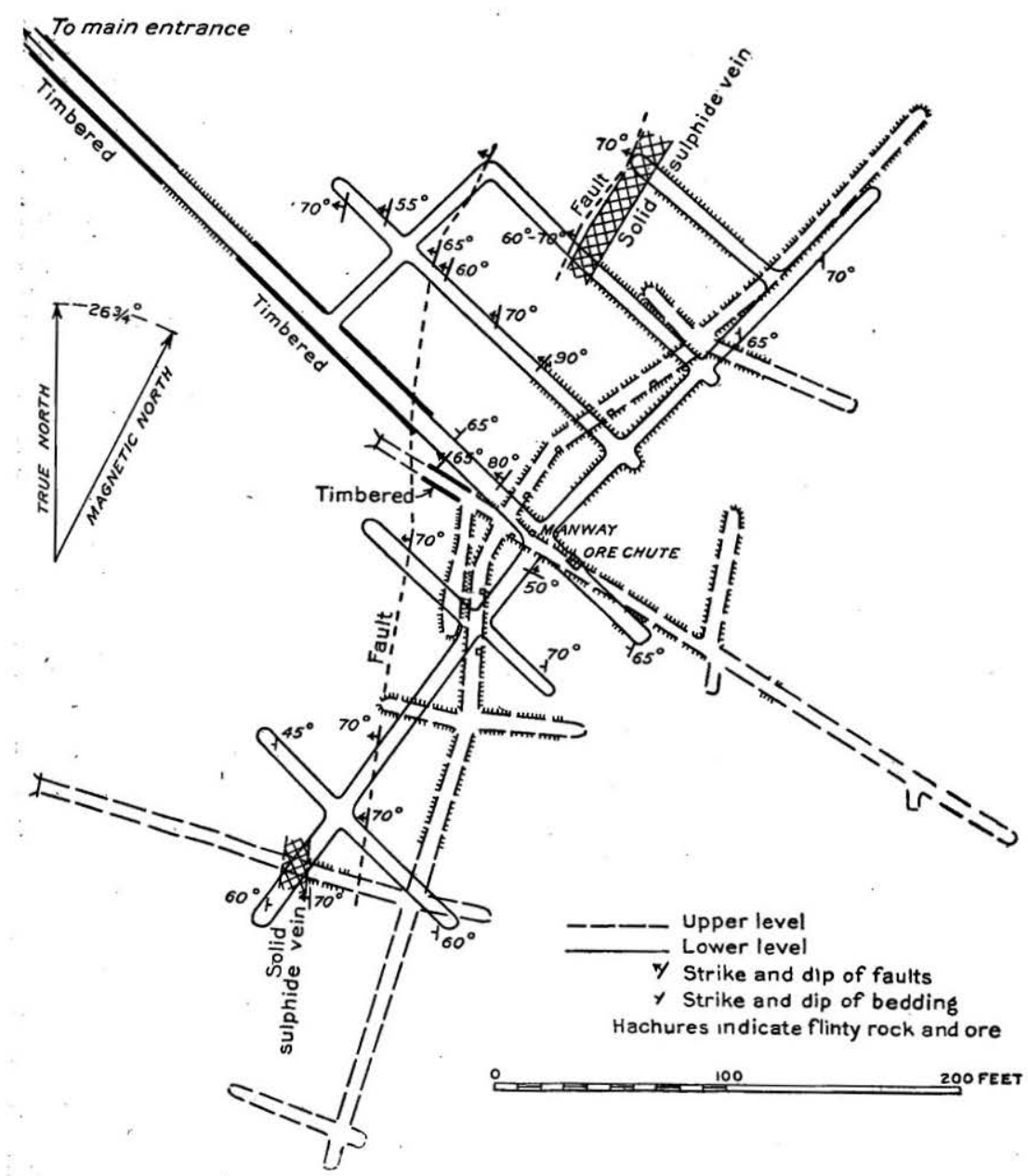

Figure 6.-Plan of underground workings at the Bonanza mine, June, 1909.

Chemical analysis of flinty rock from the Bonanza mine, Latouche Island.

[By R. C. Wells.]

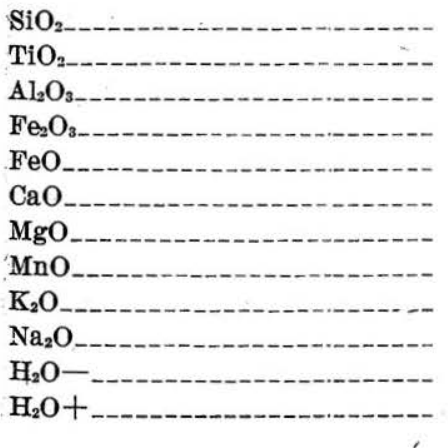

\begin{tabular}{|c|c|}
\hline 79. 40 & $\mathrm{FeS}_{2-1}$ \\
\hline .33 & $\mathrm{FeCuS}_{2}$ \\
\hline 6.11 & $\mathrm{Cu}_{----}$ \\
\hline .16 & $\mathrm{Ni} \mathbf{i}_{---}$ \\
\hline 5. 18 & Co_- - \\
\hline .29 & $\mathrm{P}_{2} \mathrm{O}_{5}$ \\
\hline 4. 13 & $\mathrm{CO}_{2}$ \\
\hline .15 & $\mathrm{ZrO}_{2---}$ \\
\hline .19 & $\mathrm{BaO}_{2}$ \\
\hline .42 & F \\
\hline $\begin{array}{r}.15 \\
2.75\end{array}$ & \\
\hline
\end{tabular}


The ore of the Bonanza mine is chiefly chalcopyrite. This occurs in fractures and as replacements of the country rock, which in large part is the greenish flinty rock already described. Ore occurs to a less extent in the graywackes and slates, and the flinty rock does not everywhere carry ore. The distribution of this flinty rock is shown in figure 6. The ore is not so widespread as this rock in the lower level, but in the upper level the distribution of the ore and that of the flinty rock are more nearly coincident.

In addition to the ore noted above there are 10-foot bands of practically solid sulphides (pyrrhotite, pyrite, and chalcopyrite). One of these outcrops in the creek just west of the mine, another is cut in the upper level at the southwestern part of the mine, and still another

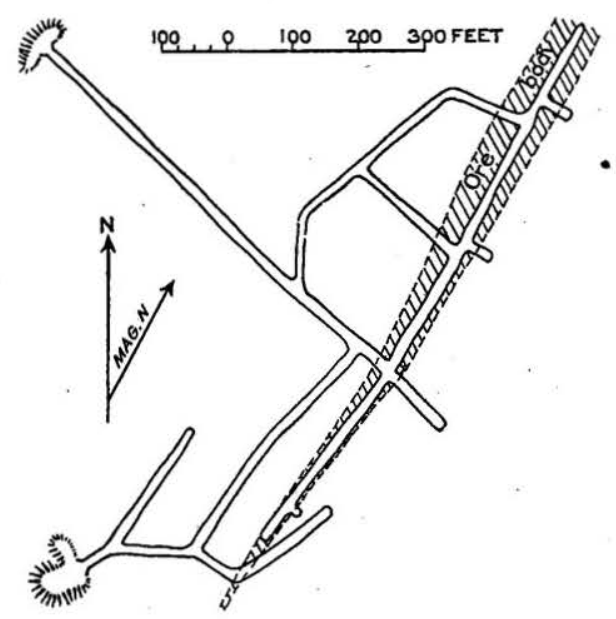

Figdre 7.-Map of tunnels and ore body on the Duchess claim of the Reynolds-Alaska Development Company, Latouche Island. occurs in the lower level at the northwestern part of the mine. Whether these bands are distinct from one another or whether they represent really only one band is not knoẁn. The solid sulphide bands cut in the workings strike north or a few degree's west of north and $\operatorname{dip} 60^{\circ}$ to $70^{\circ} \mathrm{W}$. The general strike and dip of the bedding, as shown in the slates and graywackes, are approximately parallel with those of the sulphide bands.

In the mine workings are a number of faults, a few of which are shown in figure 6 . Some of these are thrust faults; others are not clearly determinable. At least some of the faults are later than the ore deposition.

In 1910 ore bunkers having a capacity of 1,500 tons were built at the Bonanza mine, a small water-power plant was installed, and prospecting by use of the diamond drill was undertaken.

REYNOLDS-ALASKA DEVELOPMENT COMPANY.

On Horseshoe Bay the Reynolds-Alaska Development Company has built a small town, installed a pipe line and electric power plant, and constructed over a mile of corduroy road from its dock eastward to its shaft and tunnels. The shaft, reported to be 100 feet deep with a crosscut at its bottom to an ore body, was full of water at the time of visit. About half a mile northeast of the shaft and 400 feet above 
sea level some 2,000 feet of tunneling has been done, most of which is on the Duchess claim. IIere a lens-shaped body of ore has been encountered which strikes northeasterly and dips $70^{\circ} \mathrm{W}$. (See fig. 7.) It is only a few inches in thickness where first encountered at the south-southwest, but thickens gradually northward for 500 feet along the strike, reaching a thickness of 45 feet at the point to which exploration has gone. The ore body consists of pyrite and some chalcopyrite mixed with bands. of slate and graywacke. Several hundred tons of sorted ore are on the dump, and shipments are reported to have been made from this tumel.

TATOLOHIE CORPBR MINING COMPANY.

The property of the Latonche Copper Mining Company is sitnated about half a mile north of the Bonanza mine. A dock, ore bunkers, mess houses, and a tramway from the clock to the tumnel, a distance of a quarter of a mile, have been built. The property has been developed by numerous shallow pits and trenches and by a 700 -foot tumnel which strikes the ore-bearing gromd 200 feet below the surface. The ore is rock charged with chalcopyrite and some pyrrhotite and pyrite. Most of the ore removel has come from one stope, which is 45 by 15 feet in area and 5 to 10 feet in height. Severul hundred tons of ore was shipped in $190 \%$, and there is some ore remaining in the bunkers. A boiler and an air compresser were purchased for this mine in 1909.

\section{KNIGHT ISLAND.}

A large amount of prospecting was done on Knight Island in 1906 and 1907 , and much of this was curried on near Drier Bay, on the west side of the island. (Only a few of the prospects are described below.

KNIGHY'S ISLANI) CONSOLHATW (OPPBR (OMPANY.

The Knights Island Consolidated Copper Company, locally known as the Hubbard-Elliott Company, has installed a wharf, offices, ore bunkers, and steam-power plant at the northeast corner of Drier Bay. Work has been done on a number of claims, but the main development has been on two tmmels called the Monarch and the Bald Eagle. The former is 12 miles northeast of the dock and about (500 fect above the sea. Here some 3is0 feet of development work has been done. The Bald Fagle tumnel is about 900 feet above seal level and three-fourths of a mile northenst of the dock. Here is a northwestward-facing cliff with an iron-stained surface. The rock is greenstone with irregular schistose zones which wrap around masses of nonschistose rock. The schistose zones carry chalcopyrite and pyrrho- 
tite, and in some of the zones these sulphides are abundant and form ore bodies, from one of which a few hundred tons of ore has been mined. (See fig. 8.) Connecting the Bald Eagle tunnel with the dock is a wire-rope aerial tramway, the upper station of which was unfortunately somewhat damaged by a snow slide in the early part of 1908. Shipments of ore have been made from this tunnel, and some ore remains in the ore bunkers.

BUSSELL BALL COPPER COMPANY.

The prospect of the Russell Ball Copper Company is located on the south side of Drier Bay, between Barnes Cove and Mallard Bay.

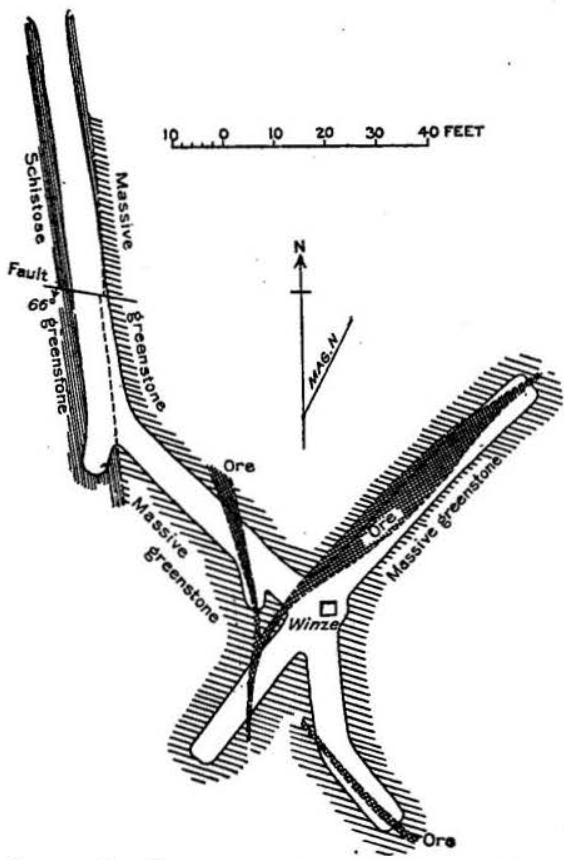

Figure 8.-Map of the tunnel and ore body on the Bald Eagle claim of the Knights Island Consolidated Copper Company, Knight Island.

The company has located six claims, four on Drier Bay and two over the ridge from Drier Bay toward Snug Harbor. The property on Drier Bay is developed by four openings. A wire-rope aerial tram operated by a windlass has been rigged from the upper tunnel to the shore. This tunnel is 520 feet above sea level and is 60 feet long upon a vein of nearly solid chalcopyrite with a little pyrrhotite. Good ontcroppings are reported to be above at an altitude of abont 1,000 feet, but these were covered with snow when visited in July, 1908. The other three openings are below, and range from 12 to 30 feet in length. They are intended to cut the vein mentioned above, but are not driven far enough to strike

it. Some ore is sacked ready for shipment, and a small shipment was made in July, 1908.

HAPPY JACK COPPER MINING AND DEVELOPMENT COMPANY.

The Happy Jack Copper Mining and Development Company's property is located on the south side of Hogan Bay, Knight Island, just at the entrance. A steam plant, an office, and mess and bunk houses have been constructed. The main work has been on a tunnel at the shore. In July, 1908, this tunnel had reached a length of 986 
feet. It is being run to intersect a vein which outcrops higher up and to the southeast. This vein extends along a fissure, cutting across the strike of the country rocks, which are slates, graywackes, and greenstones. The vein, where examined, varies from 1 to 4 feet in thickness and contains quartz, chalcopyrite, and pyrrhotite. Two tunnels have been run on this vein, one 398 feet and the other 535 feet above sea level. The upper tunnel is 85 feet in length, and the other, with its branches, about 450 feet. Several tons of ore are now on the dumps from these two tunnels and some ore has been shipped.

COPPER BULLION CLAIMS.

The Copper Bullion claims, commonly known as Rua's claims, are situated on the east side of Knight Island, and the development work consists of a tunnel, which had reached a length of 360 feet in July, 1908. This tunnel is about half a mile from the east shore of the island and $1 \frac{1}{2}$ miles north of the entrance to Marsha Harbor. The rock excavated in the tunnel is greenstone with a few stringers of pyrrhotite and chalcopyrite, but at the end a brecciated zone, cemented by quartz and these two sulphides, has been encountered. So far as the workings show, this zone is about 60 feet in width and strikes in a northeasterly direction. Some 400 feet above this tunnel, at the base of a southward-facing cliff on the south side of Iron Mountain, is an exposure of ore 65 feet in width. All of this width, except about 10 feet of mixed ore and rock, is practically solid pyrrhotite with a small percentage of chalcopyrite. About 200 feet farther

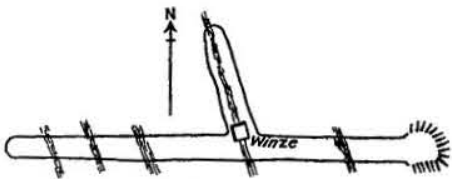

25 i 25 FEET

Figure 9.-Tunnel cutting five schistose ore-bearing zones, on property of Knights Island Mining and Development Company, near north end of Knight Island.

up the cliff the ore body appears to be 30 feet in width, and at the top of the ridge, 150 feet still higher, there is reported to be 12 feet of ore. It seems probable that the tunnel cuts this same ore body.

KNIGHTS ISLAND MINING AND DEVELOPMENT COMPANY.

At the head of Louis Bay, at the north end of Knight Island, the Knights Island Mining and Development Company has installed a small sawmill and an electric plant. From this plant electric drills have been worked in two tunnels $1 \frac{1}{2}$ miles south of the south end of this bay. One of these tunnels is 85 feet in length and cuts five schistose zones 2 to 18 inches in width, in greenstone. (See fig. 9.) These zones carry pyrite, chalcopyrite, and pyrrhotite. The main or lower tunnel was started to intersect these and several other ore-bearing 
schistose zones, and is 160 feet in length. This company is constructing a small sawmill, to be run by water power.

ORCA INLET.

In the vicinity of Orca Inlet, and especially to the east of the inlet, there are a number of copper prospects, but little work has been done on most of them. The Cordova Copper Company has done considerable prospecting on its claims between Cordova and Orca. The country rocks here are basic amygdaloids, which have been altered and irregularly fractured. In some of the fractures are copper ores, consisting of chalcopyrite, chalcocite, bornite, native copper, cuprite, and malachite. Specimens of native copper from this place were on exhibit at the Alaska-Yukon-Pacific Exposition.

In 1909 the Cordova-Tacoma Copper Company did some development work on its Head-of-the-Bay prospect, $2 \frac{1}{2}$ miles east of the north end of Cordova Bay. This prospect is situated near the contact of the country black slates and a mass of diorite.

About '10 miles northeast of Orca, near the Scott Glacier, prospectors have located some claims on veins carrying native copper.

SUMMARY.

Present developments of the copper-mining industry on Prince William Sound have demonstrated the existence of two ore deposits of commercial importance, that of the Ellamar mine and that of the Bonanza mine. The size of the former is known, but the size of the Bonanza deposit is unknown, though a large tonnage of ore is already revealed. There are, however, other properties on which development work has not yet gone far enough to establish conclusively their economic importance, but about which enough is known to encourage further careful prospecting. The location of some of these properties is at or close to tide water, and the present demand for ores of this character for furnace mixtures makes it a matter of reasonable expectation that other properties than the two mentioned above will become regularly shipping mines. This expectation will be more fully realized should the price of copper advance or should the opening of the copper mines of the Copper River district and the opening of the Bering River or the Matanuska coal field make it feasible to establish plants for the smelting of copper ores on Prince William Sound.

\section{PROSPECTING.}

In prospecting it is a good rule to follow the ore when it is found. Moreover, a certain amount of money spent in surface strippings 
and in test pits and tumnels on the ore will usually show much more concerning the value of an ore body than the same amount spent in deep underground workings. The ore bodies of the sound vary considerably in thickness and in metallic content in a horizontal direction, locally pinching out entirely; and fully as much, if not more, variation may be expected in depth. It is not good practice to drive long tumnels to intercept ore bodies at distances of a few hundred feet from the surface, until the general extent and character of the body has been pretty fully ascertained by other explorations. Where a vein or a lens-shaped body pinches out it may be well worth while to conduct explorations for a continuation of the vein or for another lens of ore along the strike of the first one.

Under present conditions a prospect to be encouraging ought to show fair promise of several thousand tons of ore which will rim at least 4 per cent in copper or, if less, enough gold and silver to counterbalance the deficiency. Under more favorable conditions than the present it will be possible to mine at a profit ore rumning less than 4 per cent in copper, especially if large bodies of low-gratle ore are discovered.

GOLD.

The copper ores which have been shipped from Prince William Sound all carry some gold. Returns from a vailable assays of these ores show from 25 cents to $\$ 4.80$ in gold to the ton of ore. Figures for the average gold content are not available, but it is estimated that it is about $\$ 1$ a ton.

\section{PLACER GOLI).}

Prospecting for placer gold has been carried on along a few of the streams entering the sound, such as Mineral and Gold creeks, on the north shore of Port Valdez, streams entering the bay in which is the Shoup Glacier, and Kings River, at the head of Port Nellie Juan. Work in these places was carried on in a small way and returns of a few dollars per day per man have been reported. A few years ago some extensive placer mining was planned for the upper part of the stream which enters Port Valdez in Solomon Gulch, but was not carried to completion.

GOLD-BE.ARING VEINS.

In connection with copper prospecting a few quartz veins have been encountered, as on Glacier Island and on the northwest slope of Copper Mountain, and these have been prospected for gold. Two assays have been made from these reins, one from the decomposed upper part of the vein and the other from the unaltered rein material 15 feet below the surface. These assays showed traces of gold and less than an ounce of silver per ton. 
Prospecting of gold-bearing veins has been carried on to a small extent in a few places about Prince William Sound. One of these is just north of the entrance to Fidalgo Bay, where a quartz vein occurs in black slate. No assays from this vein are available. Another place is one-fourth mile south of the east side of the front of the Barry Glacier, on Port Wells, where there are two gray aplite dikes a few feet in width. Practically no work has been done here, but assays of this dike material are reported to have shown $\$ 2.35$ and $\$ 2.85$ in gold to the ton.

More extensive prospecting, with encouraging results, has been carried on near McKinley Lake east of Cordova, on the north shore of Port Valdez, and on Jackpot Bay. These localities are described below.

PORT VALDEZ.

By AlFred H. Brooks.

General description.-Gold was first found near Port Valdez in the gravels at the mouth of Mineral Creek, where a little sluicing was done in 1894. In 1898 some placer claims were staked on Solomon Gulch, on the south side of Valdez Inlet, and a little sluicing was attempted. Colors of gold appear to be widely distributed in the alluvium of the region, but no workable placers have been found. Most of the streams are small and contain only a small amount of gravel.

Small auriferous quartz veins have long been known to occur on Prince William Sound, but in 1909, when the Cliff vein was discovered, none had been developed which gave assurance of being a workable deposit. The success of the Cliff mine, which has been productive since April, 1910, has greatly stimulated prospecting, and in 1910 many locations were made in the Valdez Inlet region, notably along the watersheds of Gold and Mineral creeks. The following notes are based on a very hasty visit paid to the Cliff mine in August, 1910 , and on information gathered from published reports and from prospectors.

The bed rock along the inlet appears to be chiefly slates and graywackes of the Valdez group. In places these rocks are schistose and some of the slates are graphitic. Schrader ${ }^{a}$ found some aplite dikes near Valdez. The general strike of the sediments is about east and west, parallel to the axis of Port Valdez. According to Mr. Grant the rocks on the south side of the port are closely folded and overturned to the south. On the north, so far as I could see, the rocks are also closely folded and somewhat faulted, and the dips are prevailingly to the north.

a Schrader, F. C., A reconnaissance of a part of Prince William Sound and the Copper River district, Alaska, in 1898 : Twentieth Ann. Rept. U. S. Geol. Survey, pt. 7, 1900, p. 409 . 
Where examined, the rocks showed a well-developed slaty cleavage parallel to the bedding. There appears to be a marked system of jointing which crosses the foliation nearly at right angles. The system finds expression in the topography, as it marks lines of weakness to erosional agencies. Gulches of marked regularity and parallelism are seen on the mountain side north of Port Valdez. It appears, so far as can be seen from the bay, that a number of the veins which have been opened follow this system of jointing. Prospectors, however, report that veins are found which run in various directions. These may, however, be quartz stringers and veins that follow the foliation and probably belong to a different system of fractures than that of the Cliff vein. One prospector told me that at the entrance of Valdez Bay, west of Shoup Bay, the quartz veins ran directly into the mountain, crossing the foliation at an angle of about $45^{\circ}$. These veins, though they carry gold, are not known to be of commercial value. It is asserted that the extension of the Cliff vein has been found on the Shoup Bay side, but that it takes a turn in the mountain to the northeast. There is no direct evidence of this, and on the Port Valdez side the fissuring would appear to be remarkably regular.

The Cliff mine.-The Cliff mine, which is about 8 miles from Val$\mathrm{dez}$, is located at the east end of the bluff which marks the limit of the gravel bar at the east entrance of Shoup Bay. The claim was staked in 1909 ( ?), development work began in July, 1909, and a 3-stamp mill, said to have a capacity of 30 tons a day, was installed in April, 1910. As, however, up to the time of my visit (August, 1910) only one concentrating table was in use, the mill had been run only two shifts (16 hours).

The country rock at the mine appears to be chiefly dark siliceous slate, locally graphitic and usually blocky. At the beach the strike is about east and west and the dip $20^{\circ}$ to $30^{\circ} \mathrm{N}$. The slate carries mica and is in places heavily charged with finely divided pyrite, which occurs in veinlets cutting the foliation and is also disseminated especially along the cleavage planes. There has been movement later than the formation of the pyrite, as is shown by slickensided surfaces about parallel to the cleavages.

The vein cuts across the foliation of phyllites with a strike of about N. $30^{\circ}$ to $45^{\circ} \mathrm{W}$., averaging about N. $35^{\circ} \mathrm{W}$. It dips to the southwest at an angle of about $50^{\circ}-70^{\circ}$ but has some rolls in it. The foot wall is smooth and along it there is from half an inch to 3 inches of gouge which carries values. There seems to have been no movement along the hanging wall, but it is well defined. The vein ranges in width from, say, an inch, where quartz may be entirely lacking, to 34 inches. The managers report that small swellings occur, where the vein widens to 3 and $4 \frac{1}{2}$ feet. The vein matter is in places entirely lacking, but the fissure is everywhere well defined. In one place in 
the upper tunnel a roll was encountered where a bulge in the foot wall gave a reverse dip to the vein. On the whole, the strike of the vein is fairly uniform in direction, though the workings show minor swings of $5^{\circ}$ to $10^{\circ}$. At an upper prospect tunnel, about 150 to 200 feet above the beach, what appears to be the same vein has a thickness of about a foot. So far as determined by the exposures, the vein is definitely recognizable for about 300 to 400 feet, but the managers stated that it has been traced by float throughout the length of the claim, and it is reported that the same vein has been found on the north side of the ridge, 3,000 feet from the mine.

The typical vein filling is a blue quartz carrying considerable finely disseminated pyrite and also apparently minute quantities of arsenopyrite and galena, but no detailed study of the ore has been made. Visible free gold is found, especially in the upper workings, where there has been considerable oxidation. Free gold also occurs, however, in the fresh unaltered vein material, where it is clearly not the product of alteration. In places the ore shows a rough banding, and this type is reported to carry the highest values. Some of the vein material is crushed and some shows a suggestion of brecciation and recementation.

Much of the ore is very rich, and the average recovery of free gold is reported to be about $\$ 50$ to the ton. The concentrates are said to run about 7 per cent, and have a value of about $\$ 100$ a ton in gold.

Oxidation of vein matter is very marked on the upper level, and was observed to a distance of about 100 feet from the entrance of the adit on the lower level. Beyond 100 feet on the lower adit there was no evidence of oxidation. The superintendent, Mr. Ray Millard, stated to me that there was no diminution in free-gold values with increase in depth. At the same time, the richest specimens of free gold seem to have been taken from the upper part of the mine. Values of $\$ 1.50$ to $\$ 6$ are reported in the hanging-wall rock, in which many quartz stringers were observed extending a foot or more from the vein. In the upper adit the vein matter is absent for the last 50 feet, but the fissure is traceable. It is in this part of the mine that the roll occurs.

There are two adit tunnels (which are connected by raises) 54 feet apart, and one intermediate drift. Plans are made for sinking on the vein in the lower tunnel. The lower adit is about 200 feet long.

Other prospects.-There are a number of prospects along the shore of the bay between the Cliff mine and Valdez. I did not have time to examine these, but they appear to follow fissures which parallel those of the Cliff mine. Some work has been done on several of these. At the Imperial an adit tunnel has been driven from a point near sea level along the vein for a distance of over 100 feet, and an 
air compressor is being installed. A number of other prospects have also been located on Gold Creek, Mineral Gulch, and Mineral Mountain, and many of these have yielded specimens showing free goll. From current reports, many of these prospects appear to be mere stringers, but several are reported to be large enough to warrant further exploration. Development work is being actively pushed on a number of them.

Summary.-The facts in hand appear to justify the opinion that auriferous quartz veining is not uncommon in the region adjacent to Valdez Inlet. The facts noted at the Cliff property and the reports of prospectors seem to warrant the conclusion that other auriferous veins will be found which can be profitably exploited. The Cliff mine is a splendid example of what can be accomplished by local enterprise. This mine was developed by the capital and technical skill of local men and has been managed on a conservative basis to the profit of the stockholders.

Considered in their broader relations the auriferous rocks of Valdez Inlet appear to form part of a belt of more or less altererl sediments, ${ }^{a}$ which extends northward to Klutina Lake and strikes eastward across Copper River below Wood Canyon. Within this belt some placer gold has been found on tributaries of Klutina ${ }^{b}$ and Ton$\sin ^{c}$ rivers.

East of Copper River placer gold has been found in the Brenner River basin, where some auriferous quartz is also reported, and these probably occur in the same belt of rocks, all of which suggests that, locally at least, these rocks are mineralized and justifies further prospecting for gold.

MCKINLEY LAKE.

Gold-bearing veins have long been known to occur on and just to the northwest of McKinley Lake, which empties into Alaganik Slough, of the Copper River Delta. The veins discovered lie from 1 to 2 miles northeast and north of Alaganik station on the Copper River and Northwestern Railway and about 18 miles east-sontheast of Cordova. The bed rock of the district is composed of graywacke and soft black slate of the Orca group. This locality was visited by A. C. Spencer in 1900, and he described it as follows:

At this place several veins of quartz have been opened and found to contain gold in varying quantities. A short study of this field was sufficient to show that the principal veins lie parallel to the stratification of the sedimentary rocks and that they usually follow the contact of two berls of different char-

${ }^{a}$ Schrader, F. C., A reconnaissance of a part of Prince William Sound and the Copper River district, Alaska, in 1898: Twentieth Ann. Rept. E. S. Geol. Survey, pt. 7, 1900, pp. $408-410$ and map No. 21.

${ }^{b}$ Idem, p. 422.

${ }^{c}$ Schrader, F. C., and Spencer, A. C., The geology and mineral resources of a portion of the Copper River district, Alaska; a special publication of the U. S. Geol. Survey, 1901, p. 90 . 
acter, as of massive arkose sandstone against shale. In many cases lerlyes varying in width from a few inches to several feet may be traced for long distances. In one claim the quartz shows a large amount of free gold in small stringers, but this claim has not been sufficiently exploited to determine either the permanence of the vein or its character.

Besides these veins in the planes of stratification there are others transverse to the bedding which have a width up to 4 feet and are known to be continuous for 100 feet or more. One of these, which shows no free gold, was sampled and found to contain 0.64 ounce of gold. On the whole, the Alaganik region seems worthy of the further attention of mining men.

Some development work was done in the McKinley Lake district a few years ago, but the plants were abandoned. Recently prospecting has been stimulated in this field by new discoveries, and a small stamp mill has been erected. The veins first discovered were small and carried free-milling ore, while some of the newer discoveries are reported to be larger veins carrying base ores.

\section{JACKPOT BAY.}

For several years there have been reports of the finding of "float" ore, carrying considerable values in gold, on the shores of Jackpot Bay, west of Chenega Island. In 1908 one vein carrying ore of this character was located on the east side of this bay near its head (the south end). The country rock at this locality is graywacke and graywacke slate, with a general north-northeasterly strike, parallel with the axis of the bay, and a dip of $40^{\circ}$ to $60^{\circ}$ WNW. A quarter of a mile from the shore of the bay and aproximately 770 feet above sea level an opening has been made along a vein. The opening has penetrated 8 feet into the vein and runs up the cliff side for 12 feet. The vein is a quartz vein and strikes N. $52^{\circ} \mathrm{W}$. and dips $67^{\circ} \mathrm{W}$. It is, as here exposed, 20 to 28 inches in width and has a fairly welldefined central zone which is rich in metallic sulphides-arsenopyrite, galena, and sphalerite. This central zone is 6 to 11 inches in thickness. A sample for assay was taken three times across the outer parts of the vein and also three times across the central, sulphide zone. The first sample showed 0.5 ounce of gold and 0.3 ounce of silver to the ton, or a total value of $\$ 11.89$ a ton. The second sample gave 2.5 ounces of gold and 5.9 ounces of silver to the ton, or a total value of $\$ 54.73$ a ton. ${ }^{a}$ Although this vein is small and its extent is not known, still its gold content may reasonably encourage further search for gold-bearing veins in its vicinity.

\section{CONCLUSIONS.}

The facts noted above, especially the results attained on Port Valdez, McKinley Lake, and Jackpot Bay, justify the opinion that auriferous quartz veining is not exceptionally uncommon about Prince William Sound. In one place, the Cliff mine, a producing 
property has been developed. The facts are sufficient to encourage further careful search for gold-bearing quartz veins about Prince William Sound and to justify a reasonable expectation that producing properties other than the Cliff mine may be developed. It should, however, be remembered that the proportion of veins carrying good values in gold to those carrying insignificant values will be large, and that the veins as far as known are not of large size and so may not continue for considerable distances.

The best veins already discovered are quartz veins in the slates and graywackes of the Valdez and Orca groups. No promising gold veins have yet been found in the greenstones and granites of the sound. Certain light-colored aplitic dike rocks cut the slates and graywackes in places, and locally these dikes are partly altered and contain siderite and pyrite and also probably small gold values.

\section{SILVER.}

The copper ores also carry silver in small amounts. A large number of assays show from 0.16 to 2.24 ounces of silver to the ton of ore. The average silver content of these ores is probably less than 1 ounce to the ton.

No silver prospects have been noted on the sound, and the silver content of the gold ore on Jackpot Bay has been given above.

\section{NICKEL.}

Prospecting for nickel was carried on in 1905 at two points on the shore of Prince William Sound. One is on the south side of Port Valdez, where small stringers of pyrrhotite, possibly carrying nickel, occur. The other is on the east shore of Unakwik Inlet, just north of the mouth of Miners River. There is a tunnel here 8 feet in length. The country rock is diorite, carrying disseminated pyrrhotite. The vein, if it can be so called, is a zone in the diorite impregnated with this iron sulphide and has no sharply defined walls. This sulphidebearing rock is 10 feet or more in width, and above the tunnel, which is at the water's edge, a zone of iron-stained rock, perhaps 20 feet in width, can be seen running up the cliff. Here, also, there are some pegmatitic veins in the diorite which carry pyrrhotite. These pegmatitic veins are from one-fourth inch to 2 inches in width and are not sharply defined. There are also in the dioritic country rock small fractures filled with quartz, but these do not, at least so far as seen, carry the iron sulphide. It was thought that the pyrrhotite carried considerable values of nickel and also of cobalt. Selected samples of the best ore which could be found at this particular point were assayed and the results show neither cobalt or nickel. More work has been done here since 1905, and encouraging results have been reported. 


\section{ANTIMONY.}

On the east side of the bay of Port Wells, in which is the Barry Glacier, about $1 \frac{1}{2}$ miles south of the front of this glacier, is an antimony prospect. Near the shore there are exposures of graywacke striking N. $28^{\circ} \mathrm{E}$. and dipping $45^{\circ}$ to $60^{\circ} \mathrm{W}$. Back (northeast) from the shore about 200 yards and 100 feet above the sea a few small strippings have been made on the north side of a small stream. The rocks here are black slates and graywackes, sheared and fractured. The strippings are along a zone of highly sheared rock. This zone is 6 to 8 feet in thickness, strikes N. $68^{\circ}$ E., dips $45^{\circ}$ to $65^{\circ} \mathrm{N}$., and is the breccia along a thrust fault. The rock of this zone is black slate cemented by quartz. On the foot-wall side of the zone there is 3 to 4 inches of black gouge, and on the hanging wall one-half inch to 2 inches of the same material. Next to the hanging wall, but in the sheared zone, is a layer, 1 to 8 inches thick, of quartz holding less rock than usual. This layer contains stibnite (sulphide of antimony), which is closely associated with the quartz and in some places fills little vugs in the quartz. Some movement has taken place along the fault since the deposition of the quartz and stibnite, as indicated by slickensided surfaces. The samples of this layer collected here have one-tenth to one-third of their mass stibnite. This layer is reported to have been 2 feet thick in places and to have carried much more stibnite than noted above. About 1,000 pounds of antimony ore is said to have been taken from this place.

\section{LEAD.}

Galena, the sulphide of lead, has been found in very small amounts with the copper minerals in several localities. In none of these places is it in large enough quantities to form an ore of value. It is, however, fairly abundant in the gold vein on Jackpot Bay, already described.

ZINC.

Sphalerite, the sulphide of zinc, has also been found in small amounts with the copper minerals in several localities. Some of these places are the Ellamar mine; prospects just south of Landlocked Bay; prospects near the head of Louis Bay, in the northern part of Knight Island; prospects on Herring Bay of Knight Island. So far as present prospecting has gone no bodies of ore of commercial importance have been disclosed.

IRON.

Iron-bearing sulphides (pyrite, pyrrhotite, and chalcopyrite) occur abundantly about the sound, but of course are not of value as iron ores. 
On the northwest coast of Hinchinbrook Island, about $1 \frac{1}{2}$ miles southwest of Johnstone Point, are exposures of a soft fine-grained slate or shale, gray to pinkish in color, which is heavily stained with soft red hematite. Much of the rock here resembles the "paint rock" of some of the Lake Superior iron mines, but the hematite is only in the cracks and does not run through the rock itself.

A vein of hematite, 2 feet in width, is reported from the southwestern part of Hinchinbrook Island, between the south shore of Port Etches and Signal Mountain.

Half a mile south of Louis Bay, in the northern part of Knight Island, is a shear zone in greenstone. There are 1 to 10 inches of vein material in this zone. The vein material is magnetite with pyrite and a little epidote and pyrrhotite. The vein strikes northeast and southwest and dips $80^{\circ} \mathrm{SE}$.

\section{ASBESTOS.}

On the southeast side of Elrington Island, $1 \frac{1}{2}$ miles from the northeast end of the island, is about 370 feet of tunneling exposing some quartz and calcite veins in greenstone and black to gray slate. These veins hold a little pyrrhotite, but, as far as seen, no asbestos, although the work is reported to have been done on an asbestos prospect. Near the mouth of the tunnel are several fragments of greenstone similar to that in place near at hand, carrying irregular veins of asbestos mixed with quartz. Some of these veins are 3 inches in width and the fibers of the asbestos are perpendicular to the walls of the veins.

\section{PETROLEUM.}

W. N. Armstrong reports the discovery of petroleum seepage on Eyak River about a mile south of the Copper River and Northwestern Railway.

$58668^{\circ}-\mathrm{Bull}, 443-10-6$ 


\section{RECENT SURVEY PUBLICATIONS ON ALASKA.}

[Arranged geographically. A complete list can be had on application.]

All these publications can be obtained or consulted in the following ways :

1. A limited number are delivered to the Director of the Survey, from whom they can be obtained, free of charge (except certain maps), on application.

2. A certain number are delivered to Senators and Representatives in Congress for distribution.

3. Other copies are deposited with the Superintendent of Documents, Washington, D. C., from whom they can be had at prices slightly above cost. The publications marked with an asterisk $\left(^{*}\right)$ in this list are out of stock at the Survey, but can be purchased from the Superintendent of Documents at the prices stated.

4. Copies of all government publications are furnished to the principal public libraries throughout the United States, where they can be consulted by those interested.

\section{GENERAL.}

*The geography and geology of Alaska, a summary of existing knowledge, by A. H. Brooks, with a section on climate, by Cleveland Abbe, jr., and a topographic map and description thereof, by R. U. Goode. Professional Paper 45, 1906, 327 pp. $\$ 1$.

Placer mining in Alaska in 1904, by A. H. Brooks. In Bulletin 259, 1905, pp. 18-31.

The mining industry in 1905, by A. H. Brooks. In Bulletin 284, 1906, pp. 4-9.

The mining industry in 1906, by A. H. Brooks. In Bulletin 314, 1907, pp. 19-39.

*The mining industry in 1907, by A. H. Brooks. In Bulletin 345, pp. 30-53. 45 cents.

The mining industry in 1908, by A. H. Brooks. In Bulletin 379, 1909, pp. 21-62.

The mining industry in 1909 , by $\mathrm{A}$. $\mathrm{H}$. Brooks. In Bulletin 442,1910 , pp. $20-46$.

Railway routes, by A. H. Brooks. In Bulletin 284, 1906, pp. 10-17.

Administrative report, by A. H. Brooks. In Bulletin 259, 1905, pp. 13-17.

Administrative report, by A. H. Brooks. In Bulletin 284, 1906, pp. 1-3.

Administrative report, by A. H. Brooks. In Bulletin 314, 1907, pp. 11-18.

*Administrative report, by A. H. Brooks. In Bulletin 345, 1908, pp. 5-17. 45 cents.

Administrative report, by A. H. Brooks. In Bulletin 379, 1909, pp. 5-20.

Administrative report, by A. H. Brooks. In Bulletin 442, 1910, pp. 5-19.

Notes on the petroleum fields of Alaska, by G. C. Martin. In Bulletin 259, 1905, pp. 128-139.

The petroleum fields of the Pacific coast of Alaska, with an account of the Bering River coal deposits, by G. C. Martin. Bulletin 250, 1905, 64 pp.

Markets for Alaska coal, by G. C. Martin. In Bulletin 284, 1906, pp. 18-29.

The Alaska coal fields, by G. C. Martin. In Bulletin 314, 1907, pp. 40-46.

Alaska coal and its utilization, by A. H. Brooks. In Bulletin 442, 1910, pp. 47-100.

The possible use of peat fuel in Alaska, by C. A. Davis. In Bulletin 379, 1909, pp. 63-66.

The preparation and use of peat as a fuel, by C. A. Davis. In Bulletin 442, 1910, pp. 101-132.

*The distribution of mineral resources in Alaska, by A. H. Brooks. In Bulletin 345 , pp. 18-29. 45 cents.

Mineral resources of Alaska, by A. H. Brooks. In Bulletin 394, 1909, pp. 172-207. 
Methods and costs of gravel and placer mining in Alaska, by C. W. Purington. Bulletin 263, 1905, 362 pp. 35 cents. Abstract in Bulletin 259, 1905, pp. $32-46$.

Prospecting and mining gold placers in Alaska, by J. P. Hutchins. In Bulletin 345,1908 , pp. 54-77. 45 cents.

Geographic dictionary of Alaska, by Marcus Baker; second edition by James McCormick. Bulletin 299, 1906, $690 \mathrm{pp}$.

Water-supply investigations in Alaska in 1906-7, by F. F. Henshaw and C. C. Covert. Water-Supply Paper 218, 1908, 156 pp. 25 cents.

\section{Topographic maps.}

Alaska, topographic map of; scale, 1:2,500,000. Preliminary edition by R. U. Goode. Contained in Professional Paper 45. Not published separately.

Map of Alaska showing distribution of mineral resources; scale, 1: 5,000,000; by A. H. Brooks. Contained in Bulletin 345 (in pocket).

Map of Alaska; scale, 1 : 5,000,000; by Alfred H. Brooks.

\section{SOUTHEASTERN ALASKA.}

Preliminary report on the Ketchikan mining district, Alaska, with an introductory sketch of the geology of southeastern Alaska, by Alfred H. Brooks. Professional Paper 1, 1902, 120 pp.

The Porcupine placer district, Alaska, by C. W. Wright. Bulletin 236, 1904, 35 pp. 15 cents.

The Treadwell ore deposits, by A. C. Spencer. In Bulletin 259, 1905, pp. 69-87.

Economic developments in southeastern Alaska, by F. E. and C. W. Wright. In Bulletin 259, 1905, pp. 47-68.

The Juneau gold belt, Alaska, by A. C. Spencer, pp. 1-137, and A Reconnaissance of Admiralty Island, Alaska, by C. W. Wright, pp. 138-154. Bulletin 287, 1906, 161 pp.

Lode mining in southeastern Alaska, by F. E. and C. W. Wright. In Bulletin 284, 1906, pp. 30-53.

Nonmetallic deposits of southeastern Alaska, by C. W. Wright. In Bulletin 284,1906 , pp. $54-60$.

The Yakutat Bay region, by $\mathrm{R}$. S. Tarr. In Bulletin 284, 1906, pp. 61-64.

Lode mining in southeastern Alaska, by C. W. Wright. In Bulletin 314, 1907, pp. 47-72.

Nonmetalliferous mineral resources of southeastern Alaska, by C. W. Wright. In Bulletin 314, 1907, pp. 73-81.

Reconnaissance on the Pacific coast from Yakutat to Alsek River, by Eliot Blackwelder. In Bulletin 314, 1907, pp. 82-88.

"Lode mining in southeastern Alaska in 1907, by C. W. Wright. In Bulletin 345,1908 , pp. $78-97.45$ cents.

"The building stones and materials of southeastern Alaska, by C. W. Wright. In Bulletin 345, 1908, pp. 116-126. 45 cents.

* Copper deposits on Kasaan Peninsula, Prince of Wales Island, by C. W. Wright and Sidney Paige. In Bulletin 345, 1908, pp. 98-115. 45 cents.

The Ketchikan and Wrangell mining districts, Alaska, by F. E. and C. W. Wright. Bulletin 347, 1908, 210 pp.

The Yakutat Bay region, Alaska: Physiography and glacial geology, by R. S. Tarr; Areal geology, by R. S. Tarr and B. S. Butler. Professional Paper 64, 1909, 186 pp.

Mining in southeastern Alaska, by C. W. Wright. In Bulletin 379, 1909, pp. $67-86$.

Mining in southeastern Alaska, by Adolph Knopf. In Bulletin 442, 1910, pp. 133-143.

The occurrence of iron ore near Haines, by Adolph Knopf. In Bulletin 442, 1910, pp. 144-146.

A water-power reconnaissance in southeastern Alaska, by J. C. Hoyt. In Bulletin 442, 1910, pp. 147-157.

Topographic maps.

Juneau special quadrangle; scale, 1:62,500; by W. J. Peters. For sale at 5 cents each or $\$ 3$ per hundred. 
Berners Bay special map; scale, 1: 62,500; by R. B. Oliver. For sale at 5 cents each or $\$ 3$ per hundred.

Topographic map of the Juneau gold belt, Alaska. Contained in Bulletin 287, Plate XXXVI, 1906. Not issued separately.

\section{In preparation.}

The Yakutat Bay earthquake of September, 1899, by R. S. Tarr and Lawrence Martin. Professional paper 69.

Kasaan Peninsula special map; scale, 1:62,500; by D. C. Witherspoon, J. W. Bagley, and R. H. Sargent.

Copper Mountain special map; scale, 1 : 62,500 ; by R. H. Sargent.

CONTROLLER BAY, PRINCE WILLIAM SOUND, AND COPPER RIVER REGIONS.

*The mineral resources of the Mount Wrangell district, Alaska, by W. C. Mendenhall. Professional paper 15, 1903, $71 \mathrm{pp.}$. Contains general maj of Prince William Sound and Copper River region; scale, 12 miles $=1$ inch.

Bering River coal field, by G. C. Martin. In Bulletin 259, 1905, pp. 140-150.

Cape Yaktag placers, by G. C. Martin. In Bulletin 259, 1905, pp. 88-89.

Notes on the petroleum fields of Alaska, by G. C. Martin. In Bulletin 259, 1905, pp. 128-139. Abstract from Bulletin 250.

The petroleum fields of the Pacific coast of Alaska, with an account of the Bering River coal deposits, by G. C. Martin. Bulletin 250, 1905, 64 pp.

Geology of the central Copper River region, Alaska, by W. C. Mendenhall. Professional paper 41, 1905, $133 \mathrm{pp}$.

Copper and other mineral resources of Prince William Sound, by U. S. Grant. In Bulletin 284, 1906, pp. 78-87.

Distribution and character of the Bering River coal, by G. C. Martin. In Bulletin 284, 1906, pp. 65-76.

Petroleum at Controller Bay, by G. C. Martin. In Bulletin 314, 1907, pp. 89-103.

Geology and mineral resources of Controller Bay region, by G. C. Martin. Bulletin 335, 1908, 141 pp.

*Notes on copper prospects of Prince William Sound, by F. H. Moffit. In Bulletin 345,1908 , pp. 176-178. 45 cents.

*Mineral resources of the Kotsina and Chitina valleys, Copper River region, by F. H. Moffit and A. G. Maddren. In Bulletin 345,1908 , pp. 127-175. 45 cents.

Mineral resources of the Kotsina-Chitina region, by F. H. Moffit and A. G. Maddren. Bulletin 374, 1909, $103 \mathrm{pp}$.

Copper mining and prospecting on Prince William Sound, by U. S. Grant and D. F. Higgins, jr. In Bulletin 379, 1909, pp. 87-96.

Gold on Prince William Sound, by U. S. Grant. In Bulletin 379, 1909, p. 97.

Mining in the Kotsina-Chitina, Chistochina, and Valdez Creek regions, by F. H. Moflit. In Bulletin 379, 1909, pp. 153-160.

Mineral resources of the Nabesna-White River district, by F. H. Moffit and Adolph Knopf. In Bulletin 379, 1909, pp. 161-180.

Mineral resources of the Nabesna-White River district, by $\mathrm{F}$. H. Moffit and Adolph Knopf; with a section on the Quaternary, by S. R. Capps. Bulletin $417,1910,64 \mathrm{pp}$.

Mining in the Chitina district, by F. H. Moffit. In Bulletin 442, 1910, pp. $158-163$.

Mining and prospecting on Prince William Sound, by U. S. Grant. In Bulletin 442, 1910, pp. 164-165.

\section{Topographic maps.}

Map of Mount Wrangell; scale, 12 miles $=1$ inch. Contained in Professional Paper 15. Not issued separately.

Copper and upper Chistochina rivers, scale, $1: 250,000$; by T. G. Gerdine. Contained in Professional Paper 41. Not issued separately.

Copper, Nabesna, and Chisana rivers, headwaters of ; scale, $1: 250,000$; by D. C. Witherspoon. Contained in Professional Paper 41. Not issued separately.

Controller Bay region special map; scale, 1:62,500; by E. G. Hamilton. For sale at 35 cents a copy or $\$ 21$ per hundred.

General map of Alaska coast region from Yakutat Bay to Prince William Sound; scale, 1:1,200,000; compiled by G. C. Martin. Contained in Bulletin 335. 


\section{In preparation.}

Chitina quadrangle map; scale, 1:250,000; by T. G. Gerdine and D. C. Witherspoon.

COOK INLET AND SUSITNA REGION.

The petroleum fields of the Pacific coast of Alaska, with an account of the Bering River coal deposits, by G. C. Martin. Bulletin 250, 1905, 64 pp.

Coal resources of southwestern Alaska, by R. W. Stone. In Bulletin 259, 1905, pp. 151-171.

Gold placers of Turnagain Arm, Cook Inlet, by F. H. Moffit. In Bulletin 259, 1905, pp. $90-99$.

Mineral resources of the Kenai Peninsula; Gold fields of the Turnagain Arm region, by F. H. Moffit, pp. 1-52; Coal fields of the Kachemak Bay region, by R. W. Stone, pp. 53-73. Bulletin 277, 1906, 80 pp.

Preliminary statement on the Matanuska coal field, by G. C. Martin. In Bulletin 284, 1906, pp. 88-100.

'A reconnaissance of the Matanuska coal field, Alaska, in 1905, by G. C. Martin. Bulletin 289, 1906, 36 pp.

Reconnaissance in the Matanuska and Talkeetna basins, by Sidney Paige and Adolph Knopf. In Bulletin 314, 1907, pp. 104-125.

Geologic reconnaissance in the Matanuska and Talkeetna basins, Alaska, by Sidney Paige and Adolph Knopf. Bulletin 327, 1907, 71 pp.

Notes on geology and mineral prospects in the vicinity of Seward, Kenai

Peninsula, by U. S. Grant and D. F. Higgins. In Bulletin 379, 1909, pp. 98-107.

Preliminary report on the mineral resources of the southern part of Kenai Peninsula, by U. S. Grant and D. F. Higgins. In Bulletin 442, 1910, pp. 166-178.

Outline of the geology and mineral resources of the Iliamna and Clark lakes region, by G. C. Martin and F. J. Katz. In Bulletin 442, 1910, pp. 179-200.

Gold placers of the Mulchatna, by F. J. Katz. In Bulletin 442, 1910, pp. 201-202.

\section{T'opographic maps.}

Kenai Peninsula, northern portion ; scale, $1: 250,000$; by E. G. Hamilton. Contained in Bulletin 277. Not published separately.

Reconnaissance map of Matanuska and Talkeetna region; scale, 1:250,000; by T. G. Gerdine and R. H. Sargent. Contained in Bulletin 327. Not published separately.

Mount McKinley region; scale, $1: 625,000$; by D. L. Reaburn. Contained in Professional Paper 45. Not published separately.

\section{In preparation.}

The Mount McKinley region, by A. H. Brooks, with descriptions of the igneous rocks and of the Bonnifield and Kantishna districts by $\mathrm{L}$. M. Prindle. Professional Paper 70 .

\section{ALASKA PENINSULA AND ALEUTIAN ISLANDS.}

Gold mine on Unalaska Island, by A. J. Collier. In Bulletin 259, 1905, pp. 102-103.

Gold deposits of the Shumagin Islands, by G. C. Martin. In Bulletin 259, 1905, pp. 100-101.

Notes on the petroleum fields of Alaska, by G. C. Martin. In Bulletin 259, 1905, pp. 128-139. Abstract from Bulletin 250.

The petroleum fields of the Pacific coast of Alaska, with an account of the Bering River coal deposits, by G. C. Martin. In Bulletin 250, 1905, 64 pp.

Coal resources of southwestern Alaska, by $\mathrm{R}$. W. Stone. In Bulletin 259, 1905, pp. 151-171.

The Herendeen Bay coal field, by Sidney Paige. In Bulletin 284, 1906, pp. 101-108.

Mineral resources of southwestern Alaska, by W. W. Atwood. In Bulletin 379. 1909, pp. 108-152.

\section{In preparation.}

Geology and mineral resources of parts of Alaska Peninsula, by W. W. Atwood. 
YUKON BASIN.

The coal resources of the Yukon, Alaska, by A. J. Collier. Bulletin 218, 1903, $71 \mathrm{pp}$.

*The gold placers of the Fortymile, Birch Creek, and Fairbanks regions, by I. M. Prindle. Bulletin 251, 1905, 89 pp. 35 cents.

Yukon placer fields, by L. M. Prindle. In Bulletin 284, 1906, pp. 109-131.

Reconnaissance from Circle to Fort Hamlin, by R. W. Stone. In Bulletin 2\$4, 1906, pp. 128-131.

The Yukon-Tanana region, Alaska; description of the Circle quadrangle, by L. M. Prindle. Bulletin 295, 1906, 27 pp.

The Bonnifield and Kantishna regions, by L. M. Prindle. In Bulletin 314, 1907, pp. 205-226.

The Circle precinct, Alaska, by Alfred H. Brooks. In Bulletin 314, 1907, pp. 187-204.

The Yukon-Tanana region, Alaska; description of the Fairbanks and Rampart quadrangles, by L. M. Prindle, F. L. Hess, and-C. C. Covert. Bulletin 337, $1908,102 \mathrm{pp}$.

*Occurrence of gold in the Yukon-Tanana region, by L. M. Prindle. In Bulletin 345,1908 , pp. 179-186. 45 cents.

*The Fortymile gold placer district, by L. M. Prindle. In Bulletin 345, 1908, pp. 187-197. 45 cents.

Water-supply investigations in Alaska, 1906 and 1907, by F. F. Henshaw and C. C. Covert. Water-Supply Paper 218, 1908, $156 \mathrm{pp}$.

*Water supply of the Fairbanks district in 1907, by C. C. Covert. In Bulletin 345,1908 , pp. 198-205. 45 cents.

The Fortymile quadrangle, by L. M. Prindle. Bulletin 375, 1909, 52 pp.

Water-supply investigations in Yukon-Tanana region, 1906-1908, by C. C. Covert and C. E. Ellsworth. Water-Supply Paper 228, 1909, 108 pp.

The Fairbanks gold-placer region, by L. M. Prindle and F. J. Katz. In Bulletin 379, 1909, pp. 181-200.

Water supply of the Yukon-Tanana region, 1907-8, by C. C. Covert and C. E. Ellsworth. In Bulletin 379, 1909, pp. 201-228.

Gold placers of the Ruby Creek district, by A. G. Maddren. In Bulletin 379, 1909, pp. 229-233.

Placers of the Gold Hill district, by A. G. Maddren. In Bulletin 379, 1909, pp. 234-237.

Gold placers of the Innoko district, by A. G. Maddren. In Bulletin 379, 1909, pp. 238-266.

The Innoko gold-placer district, with accounts of the central Kuskokwim Valley and the Ruby Creek and Gold Hill placers, by A. G. Maddren. Bulletin 410, 1910, 87 pp.

Sketch of the geology of the northeastern part of the Fairbanks quadrangle, by L. M. Prindle. In Bulletin 442, 1910, pp. 203-209.

The auriferous quartz veins of the Fairbanks district, by L. M. Prindle. In Bulletin 442, 1910, pp. 210-229.

Placer mining in the Yukon-Tanana region, by C. E. Ellsworth. In Bulletin 442,1910 , pp. 230-245.

Occurrence of wolframite and cassiterite in the gold placers of Deadwood Creek, Birch Creek district, by B. L. Johnson. In Bulletin 442, 1910, pp. 246-250.

Water supply of the Yukon-Tanana region, 1909, by C. E. Ellsworth. In Bulletin 442. 1910, pl. 251-283.

The Koyukuk-Chandalar gold region, by A. G. Maddren. In Bulletin 442, 1910, pp. 284-315.

\section{Topographic maps.}

Fortymile quadrangle; scale, 1:250,000; by E. C. Barnard. For sale at 5 cents a copy or $\$ 3$ per hundred.

The Fairbanks quadrangle; scale, $1: 250,000$; by T. G. Gerdine, D. C. Witherspoon, and $R$. B. Oliver. For sale at 10 cents a copy or $\$ 6$ per hundred.

Rampart quadrangle; scale, 1:250,000; by D. C. Witherspoon and $R$. $B$. Oliver. For sale at 10 cents a copy or $\$ 6$ per hundred.

Fairbanks special map; scale, 1:62,500; by T. G. Gerdine and R. H. Sargent. For sale at 10 cents a copy or $\$ 6$ per hundred.

Yukon-Tanana region, reconnaissance map of; scale, 1:625,000; by T. G. Gerdine. Contained in Bulletin 251, 1905. Not published separately. 
Fairbanks and Birch Creek districts, reconnaissance maps of ; scale, $1: 250,000$; by 'I'. G. Gerdine. Contained in Bulletin 251, 1905. Not issued separately. Circle quadrangle, Yukon-Tanana region; scale, $1: 250,000$; by D. C. Witherspoon. Contained in Bulletin 295. In print as separate publication.

\section{In preparation.}

Geology and mineral resources of Fairbanks quadrangle, by L. M. Prindle.

\section{SEWARD PENINSULA.}

A reconnaissance of the Cape Nome and adjacent gold fields of Seward Peninsula, Alaska, in 1900, by A. H. Brooks, G. B. Richardson, and A. J. Collier. In a special publication entitled "Reconnaissances in the Cape Nome and Norton Bay regions, Alaska, in 1900," 1901, $180 \mathrm{pp}$.

A reconnaissance in the Norton Bay region, Alaska, in 1900, by W. C. Mendenhall. In a special publication entitled "Recomnaissances in the Cape Nome and Norton Bay regions, Alaska, in 1900."

A reconnaissance of the northwesteru portion of Seward Peninsula, Alaska, by A. J. Collier. Professional Paper 2, 1902, $70 \mathrm{pp}$.

The tin deposits of the York region, Alaska, by A. J. Collier. Bulletin 229, $1904,61 \mathrm{pp}$.

Recent developments of Alaskan tin deposits, by A. J. Collier. In Bulletin 259, 1905, pp. 120-127.

The Fairhaven gold placers of Seward Peninsula, by F. H. Motfit. Bulletin $247,1905,85 \mathrm{pp}$.

The York tin region, by F. L. Hess. In Bulletin 284, 1906, pp. 145-157.

Gold mining on Seward Peninsula, by F. H. Moffit. In Bulletin 284, 1906 , pp. 132-141.

The Kougarok region, by A. H. Brooks. In Bulletin 314, 1907, pp. 164-181.

*Water supply of Nome region, Seward Peninsula, Alaska, 1906, by J. C. Hoyt and F. F. Henshaw. Water-Supply Paper 196, 1907, 52 pp. 15 cents.

Water supply of the Nome region, Seward Peninsula, 1906, by J. C. Hoyt and F. F. Henshaw. In Bulletin 314, 1907, pp. 182-186.

The Nome region, by F. H. Moffit. In Bulletin 314, 1907, pp. 126-145.

Gold fields of the Solomon and Niukluk river basins, by P. S. Smith. In Bulletin 314, 1907, pp. 146-156.

Geology and mineral resources of Iron Creek, by P. S. Smith. In Bulletin 314, 1907, pp. 157-163.

The gold placers of parts of Seward Peninsula, Alaska, including the Nome, Council, Kougarok, Port Clarence, and Goodhope precincts, by A. J. Collier, F. L. Hess, P. S. Smith, and A. H. Brooks. Bulletin 328, 1908, pp. 343.

*Investigation of the mineral deposits of Seward Peninsula, by P. S. Smith. In Bulletin 345, 1908, pp. 206-250. 45 cents.

*The Seward Peninsula tin deposits, by Adolph Knopf. In Bulletin 345, 1908, pp. 251-267. 45 cents.

* Mineral deposits of the Lost River and Brooks Mountain regions, Seward Peninsula, by Adolph Knopf. In Bulletin 345, 1908, pp. 268-271. 45 cents.

*Water supply of the Nome and Kougarok regions, Seward Peninsula, in 1906-7, by F. F. Henshaw. In Bulletin 345, 1908, pp. 272-285. 45 cents.

Water-supply investigations in Alaska, 1906 and 1907, by F. F. Henshaw and C. C. Covert. Water-Supply Paper 218, 1908, pp. 156.

Geology of the Seward Peninsula tin deposits, by Adolph Knopf. Bulletin 358, 1908, pp. 72 .

Recent developments in southern Seward Peninsula, by P. S. Smith. In Bulletin 379, 1909, pp. 267-301.

The Iron Creek region, by P. S. Smith. In Bulletin 379, 1909, pp. 302-354.

Mining in the Fairhaven precinct, by F. F. Henshaw. In Bulletin 379, 1909, pp. 355-369.

Water-supply investigations in Seward Peninsula in 1908, by F. F. Henshaw. In Bulletin 379, 1909, pp. 370-401.

Geology and mineral resources of the Solomon and Casadepaga quadrangles, Seward Peninsula, by P. S. Smith. Bulletin 433, 1910, 234 pp.

Mineral resources of the Nulato-Council region, by P. S. Smith and H. M. Eakin. In Bulletin 442, 1910, 11). 316-352. 


\section{8̂6 RECONNAISSANCE OF PRINCE WILLIAM SOUND́, AZ̈AŚK̈A.}

Mining in Seward Peninsula, by F. F. Henshaw. In Bulletin 442, 1910, pp. 353-371.

Water-supply investigations in Seward Peninsula in 1909, by F. F. Henshaw. In Bulletin 442, 1910, pp. 372-418.

\section{Topographic maps.}

The following maps are for sale at 5 cents a copy, or $\$ 3$ per hundred:

Casadepaga quadrangle, Seward Peninsula; scale, 1:62,500; by T. G. Gerdine. Grand Central special, Seward Peninsula; scale, 1:62,500; by T. G. Gerdine.

Nome special, Seward Peninsula ; scale, 1:62,500; by T. G. Gerdine.

Solomon quadrangle, Seward Peninsula; scale, 1:62,500; by T. G. Gerdine.

The following maps are for sale at 25 cents a copy, or $\$ 15$ per hundred:

Seward Peninsula, northeastern portion of, topographic reconnaissance of ; scale, $1: 250,000$; by T. G. Gerdine.

Seward Peninsula, northwestern portion of, topographic reconnaissance of ; scale, $1: 250,000$; by T. G. Gerdine.

Seward Peninsula, southern portion of, topographic reconnaissance of; scale, 1: 250,$000 ;$ by T. G. Gerdine.

\section{In preparation.}

Geology of the area represented on the Nome and Grand Central special maps; by F. H. Moffit, F. L. Hess, and P. S. Smith.

The water resources of Seward Peninsula; by F. F. Henshaw.

\section{NORTHERN ALASKA.}

A reconnaissance from Fort Hamlin to Kotzebue Sound, Alaska, by way of Dall, Kanuti, Allen, and Kowak rivers; by W. C. Mendenhall. Professional Paper 10, 1902, pp. 68.

*A reconnaissance in northern Alaska across the Rocky Mountains, along the Koyukuk, John, Anaktuvuk, and Colville rivers, and the Arctic coast to Cape Lisburne, in 1901; by F. C. Schrader and W. J. Peters. Professional Paper 20, 1904, pp. 139.

Coal fields of the Cape Lisburne region; by A. J. Collier. In Bulletin 259, 1905, pp. 172-185.

Geology and coal resources of Cape Lisburne region, Alaska; by A. J. Collier. Bulletin 278, 1906, pp. 54 .

\section{Topographic maps.}

Fort Yukon to Kotzebue Sound, reconnaissance map of; scale, 1:1,200,000: by D. L. Reaburn. Contained in Professional Paper 10. Not published separately.

Koyukuk River to mouth of Colville River, including John River; scale. $1: 1,200,000$; by W. J. Peters. Contained in Professional Paper 20. (Out of stock.) Not published separately. 


\section{INDEX.}

A. Page.

Acidic dikes, occurrence and character of. 20,46-48 Acknowledgments to those aiding.

Amphibole, photomicrograph of

Antimony, occurrence of.

Asbestos, occurrence of.

\section{B}

Barry Glacier, dikes at.................. $\quad 47$ Basic intrusive rocks, occurrence and character of.

relations of, to copper................ 58

Bettles, J. J., acknowledgments to......... 13

Bligh Island, rocks near.................. 28

Bonanza copper mine, description of ...... 63

location of . . . . . . . . .

ores of .......................... 56,58,65

plans and section of, figures showing.... 64,65

rock at, analysis of ................. 65

views at.............................. 64

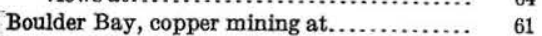

Brenner River basin, gold in.............. 75

Brooks, Alfred H., on Port Valdez gold occurrences ................... 72-75

preface by $\ldots \ldots \ldots \ldots \ldots \ldots \ldots \ldots \ldots \ldots, 7-8$

C.

Tedar Bay granite, analyses of. .

Chalcopyrite, occurrence and character of.... 53

Chugach Gulf, present name of............. 2

Chugach Mountains, description of ......... 14-15

Cirques, occurrence of..................... 19

Cliff gold mine, description of............ 72-74

Columbia Bay, view at.................... 18

Columbia Glacier, location and character of.. 20

Copper, derivation of..................... 8

exploitation of....................... 52-53

occurrence of ......................... 12

ores of . . 53-59

origin of ................... $8,57-59$

production of............................

prospecting for .................... 70-71

Copper Bullion claims, description of........ 69

Copper mines, descriptions of............. $59-70$ location of ........................... 12,52

Copper mining, prospects of.............. 70

Cordova, description of ..................

views from............................ 14

Cordova Copper Co., work of ................ 70

Cordova-Tacoma Copper Co., work of....... 70

Cuilross Island, granite on............. 37-38

D.

Diabase, occurrence and character of...... 20,50-51

Dikes, acidic, occurrence and character of $20,46-48$

Diorite, occurrence and character of.
E.

Page.

Economic geology, account of........... 52-79

Ellamar, copper mining near............. 59-61

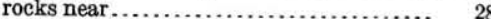

Ellamar copper mine, description of ....... $59-61$ location of ......................... 12,52 ores of ............................ 56

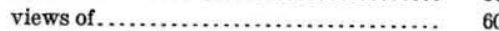

workings of, plan showing .............. 60

Ellipsoidal greenstones, occurrence and character of ...........................

views of .............................. 26

Elrington Island, rocks of................ 31

Eshamy granite, occurrence and character of. 34-35 photomicrographs of.................. 36

Esther granite, analyses of................. 46 occurrence and character of ............ 39-41 photomicrograph of.................. $\quad 36$

Esther Island, gabbro on................

Explorations, progress of................ 12-13

Ewan Bay, granite on .................... 34

F.

Faults, effect of, on topography............ 16

Fidalgo-Alaska Copper Co., mine of............ 63

Fidalgo Bay, copper mining at.............. 62 view near............................. 16

Fidalgo Bay Mining Co., mine of........... 63

Field work, extent of.................... 7

Flats, location and character of . ......... 16-17 view of .............................. 16

G.

Gabbro, occurrence and character of .... 20,49-50

Galena, occurrence of....................... 54

Galena Bay, copper mining on................. 59 rocks on ........................... 26-28 section on, figure showing ............. 27

Galena Bay Mining Co., mine of........... $\quad 59$

Geography, description of................ 9,11

Geologic map of Latouche Island............ Pocket. of Prince William Sound............... Pocket. preparation of .................... 13

Geology, descriptive, account of.......... 20-52 outline of.......................... 11-12

Geology, economic, account of........... 52-79

Giant Rocks, dikes at.................. 48

Glaciation, description of .................. 18-20 evidences of, view of.................... 18

Glacier Bay, granite on.................... 44

Gold, occurrence of, description of........ 72-77 occurrence of, methods of............. 71-72 production of ...................... 53,71 prospects of...................... 76-77

Granite, analyses of..................... 45 composition of..................... 44-46 
Page.
Pranite photomicrographs of................. 36 Grant, U. S., work of .................... 13

Graywacke, occurrence and character of..... 20-21

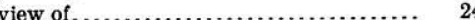

Greenstone, occurrence and character of..... 51-52 views of . . . . . . . . . .

Gull Island, view on

H.

Happy Jack Copper Mining and Development Co., mine of ............. 68-69

section of, figure showing.............. 69

Harriman Alaska Expedition, on Prince William Sound............ 12-13,32

Harriman Fiord, dikes on ............... 47

Hematite, occurrence of ................. $\quad 79$

Hoodoo Island, rocks of................. 31

\section{I.}

Igneous rocks, description of.

J.

Jackpot Bay, gold mines on . lead at.

K.

Kindle, E. M., fossils determined by........ 33

Knight Island, copper mines on . ........ 56, 67-70 rocks of. .......................... 28 views on.............................. 18

Knight Island Consolidated Copper Co., mine of. $67-69$

Knight Island Mining and Development Co., mine of.. . $69-70$

Knowlton, F. H., fossils determined by...... 23

\section{L.}

Landlocked Bay, copper mining at

views on and near................... 16,60

$61-62$

Latouche Copper Mining Co, mine of . 67

Latouche Island, copper mines on . . . . . . . 63-67 gabbro on ....................... 49-50

glaciation on ......................... 19

investigations on .................... 7

rocks of...............................

map of . . ............................ 29

sections on, figures showing............ 29, 30

views on $\ldots \ldots \ldots, \ldots \ldots \ldots \ldots \ldots \ldots \ldots .64$

Lead, occurrence of..................... 78

Level, changes in.................... 17-18

\section{M.}

McKinley Lake, gold mines on ........... 75-76

Map, of Latouche Island................. Pocket. of Prince William Sound ............... 10 key to.

Map, geologic of Latouche Island.

of Prince William Sound................. Pocket.

preparation of

Mendenhall, W. C., on Prince William Sound.
Mineral deposits, character of Page.

Minerals, occurrence and character of, with copper.................... 53-54

Moffit, F. H., on Prince William Sound.... 13$$
\text { N. }
$$

Nellie Juan granite, analyses of.

occurrence and character of............. 37

Nickel, occurrence of .................. 77

Nikolai greenstone, correlation of........... 8

\section{O.}

Orca, copper near ............... 56-57,58,70

Orca group, age of .................... 32 fossils in......................... 32 occurrence and character of... . 7-8,11,21,25-31 view of ........................... 24

Orea Inlet, copper mines on ............. 70

Orthoclase, photomicrograph of............ 30

P.

Paddy Bay, granite at................. 34

Paige, Sidney, work of .................... 13

Passage Canal, granite on................. $38-39$

Petroleum, occurrence of ................ $\quad 79$

Port Bainbridge, granite on .............. 44

Port Gravina, granite on ................. 43

Port Valdez, gold at... ................ $72-75$

nickel at................................. 77

Port Valdez Fiord, description of........... 15

Port Wells, antimony at................. $\quad 78$

Port Wells Fiord, description of ........... 15

Prince William Sound Mining Co., mine of... 59

Pyrite, occurrence and character of ......... 53

Pyrrhotite, occurrence and character of ..... $\quad 53$

Q.

Quartz porphyry, photomicrograph of.......

R.

Railways, routes of ..................... 11

Reynolds-Alaska Development Co., mines

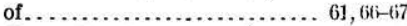

plan of, figure showing................ 66

Rocky Point, views at.................. 24, 26

S.

Schrader, F. C., on Prince William Sound... 12, 23, 32, 48 Schrader, F. C., and Spencer, A. C., on Prince William Sound............ 13,24,32 Sedimentary rocks, description of........... 20-33 Settlements, description of............... 11 Sheep Bay granite, analyses of.............. 45 occurrence and character of............ 43-44

Silver, occurrence of ...................... 77 production of....................... 53

Slate, occurrence and character of........... 20-21 view of .................................. 24 Spencer, A. C., on McKinley Lake......... 75-76 Spencer, A. C., and Schrader, F. C., on Prince William Sound............ 13, 24,32

Sphalerite, occurrence of ................. 13, 24, 32 


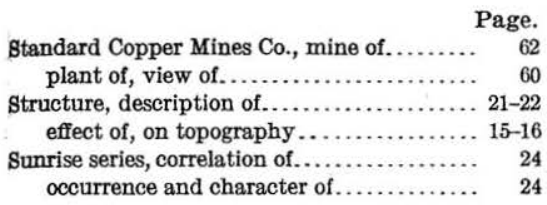

T.

Tatitlek Narrows, diabase in.

Three Giants, view of . . . .

Three Man Mining Co., mine of.

Toboggan Glacier, dike at.

Topography, changes in. description of.

\section{U.}

Ulrich, E. O., on Yakutat series.

Unakwik Inlet, diabase on

dikes on

nickel at.

50-51

$47-48$
V.

Page.

Valdez, description of.................. 11

Valdez group, age of................. 21, 23-24

correlation of ....................... 24

fossils in........................ 23-24

occurrence and character of.... 7-8,11,21, 22-23

structure of................................. 23

Valdez Inlet, gold on .................... $\quad 75$

Valdez Narrows, dikes at.............. 48,50

Valleys, location and character of......... 15-16

Van Hise, C. R., cited.................. 49

Vesuvius Valley, copper mining in....... 59

W.

Wells Bay, granite on................. 41-43

Whalen and Nelson prospect, description of.. 62-63

Y.

Yakutat series, occurrence and character of.. 33

Zinc, occurrence of...

Z. 










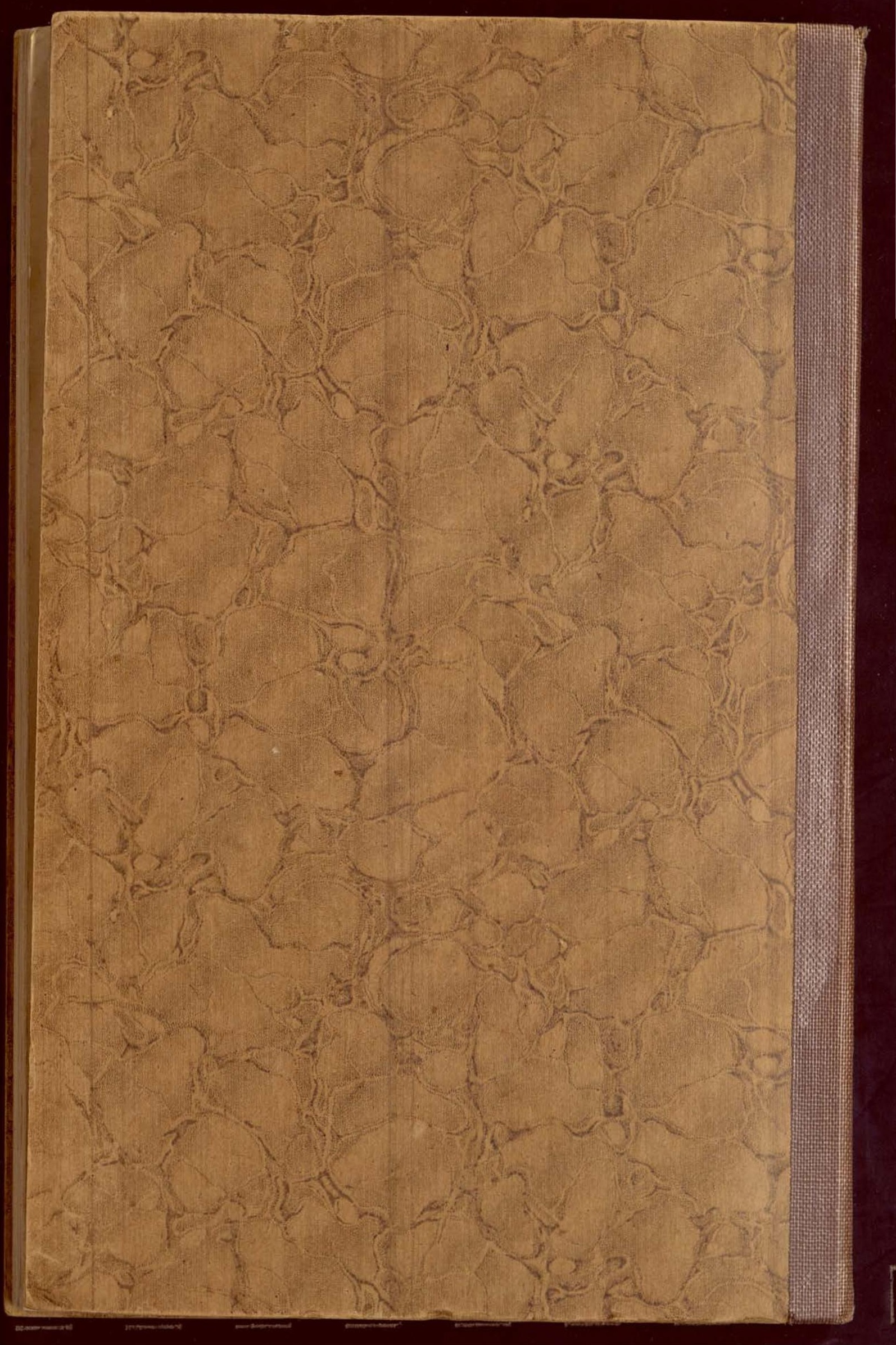




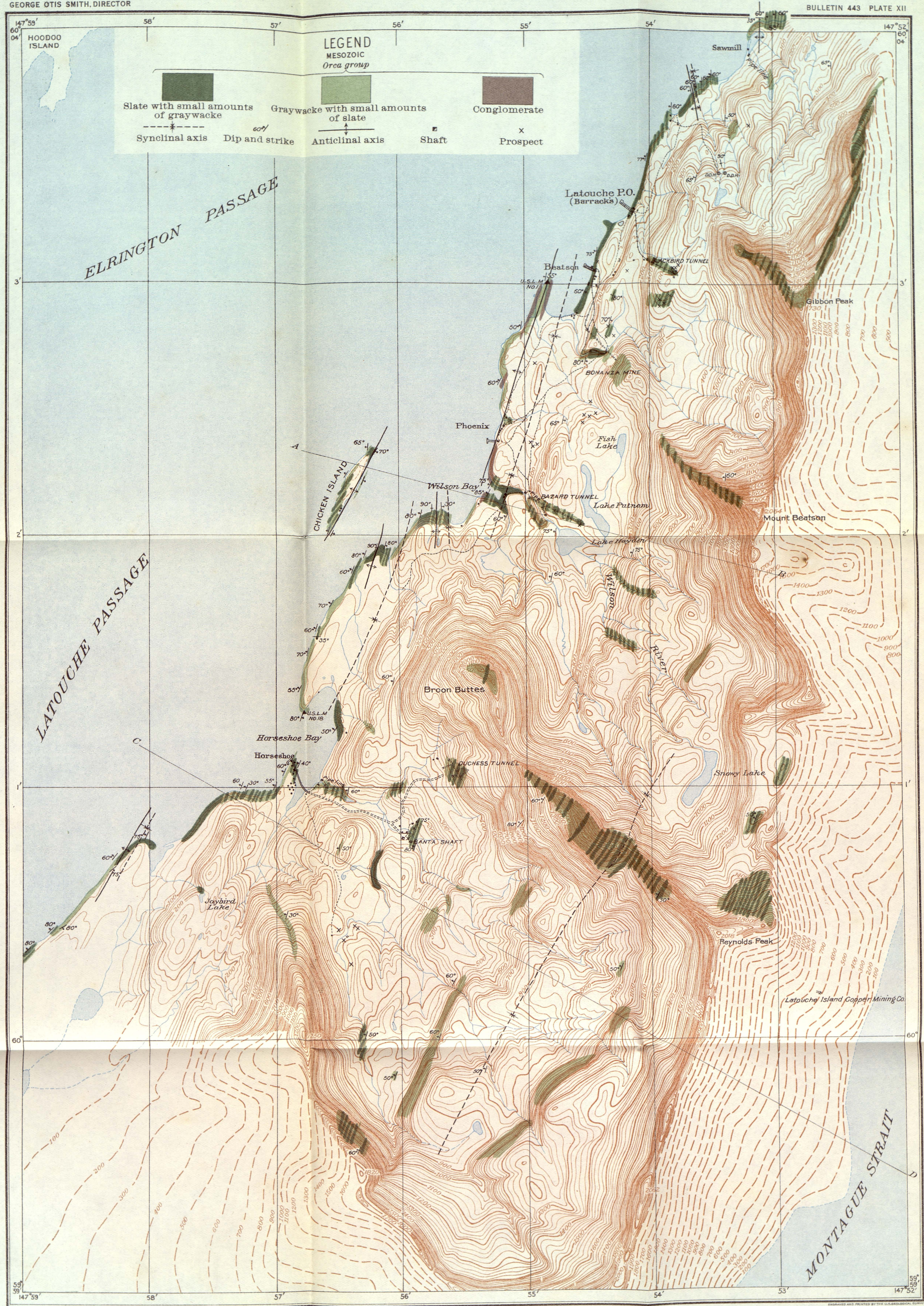

TOPOGRAPHIC AND GEOLOGIC MAP OF PART OF LATOUCHE ISLAND, PRINCE WILLIAM SOUND, ALASKA

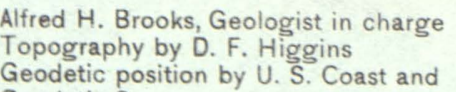
Geodteic opsition by U. S. Coas
Geodetic Survey 